\title{
ANSI/ASHRAE/IES Standard 90.1-2013 Preliminary Determination: Quantitative Analysis
}

$\begin{array}{ll}\text { M Halverson } & \text { R Athalye } \\ \text { M Rosenberg } & \text { Y Xie } \\ \text { W Wang } & \text { R Hart } \\ \text { J Zhang } & \text { S Goel } \\ \text { V Mendon } & \end{array}$

March 2014

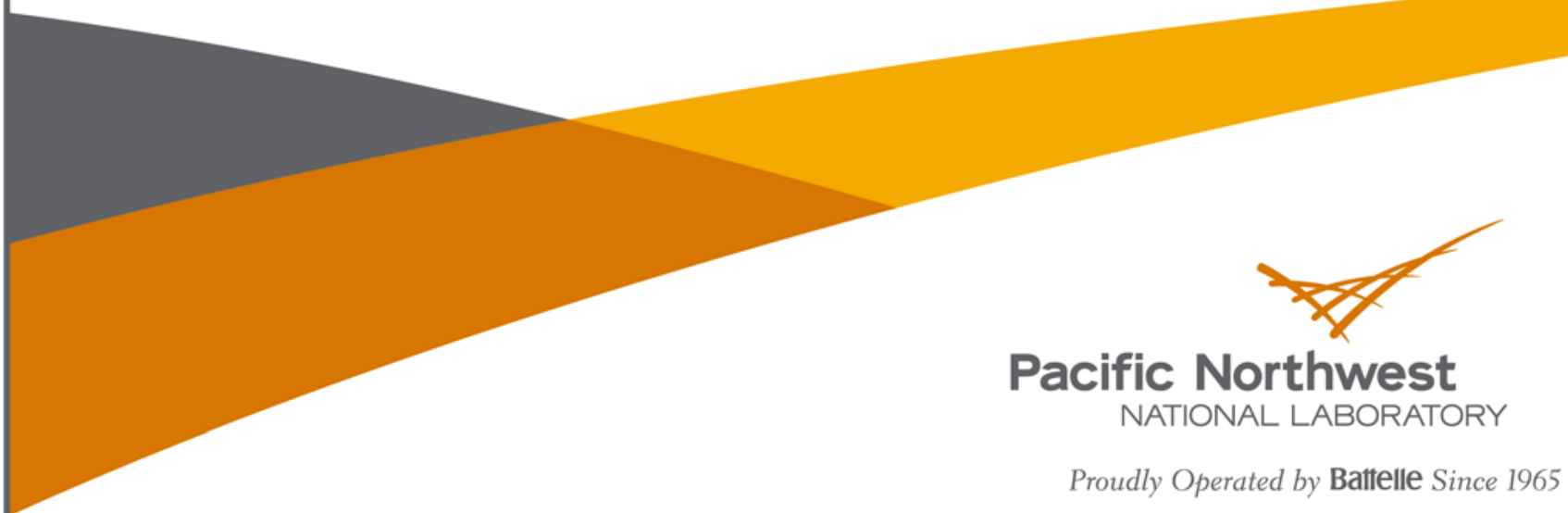




\title{
DISCLAIMER
}

This report was prepared as an account of work sponsored by an agency of the United States Government. Neither the United States Government nor any agency thereof, nor Battelle Memorial Institute, nor any of their employees, makes any warranty, express or implied, or assumes any legal liability or responsibility for the accuracy, completeness, or usefulness of any information, apparatus, product, or process disclosed, or represents that its use would not infringe privately owned rights. Reference herein to any specific commercial product, process, or service by trade name, trademark, manufacturer, or otherwise does not necessarily constitute or imply its endorsement, recommendation, or favoring by the United States Government or any agency thereof, or Battelle Memorial Institute. The views and opinions of authors expressed herein do not necessarily state or reflect those of the United States Government or any agency thereof.

\author{
PACIFIC NORTHWEST NATIONAL LABORATORY \\ operated by \\ BATTELLE \\ for the \\ UNITED STATES DEPARTMENT OF ENERGY \\ under Contract DE-AC05-76RL01830
}

Printed in the United States of America
Available to DOE and DOE contractors from the Office of Scientific and Technical Information,
P.O. Box 62, Oak Ridge, TN 37831-0062;
ph: (865) 576-8401
fax: $(865) 576-5728$
email: reports@adonis.osti.gov
Available to the public from the National Technical Information Service
5301 Shawnee Rd., Alexandria, VA 22312 ph: (800) 553-NTIS (6847)
email: orders@ntis.gov $<$ http://www.ntis.gov/about/form.aspx $>$
Online ordering: http://www.ntis.gov

This document was printed on recycled paper. 


\section{ANSI/ASHRAE/IES Standard 90.1-2013 Preliminary Determination: Quantitative Analysis}

$\begin{array}{ll}\text { M Halverson } & \text { R Athalye } \\ \text { M Rosenberg } & \text { Y Xie } \\ \text { W Wang } & \text { R Hart } \\ \text { J Zhang } & \text { S Goel } \\ \text { V Mendon } & \end{array}$

March 2014

Prepared for

the U.S. Department of Energy

under Contract DE-AC05-76RL01830

Pacific Northwest National Laboratory

Richland, Washington 99352 



\section{Executive Summary}

Section 304(b) of the Energy Conservation and Production Act (ECPA), as amended, requires the Secretary of Energy to make a determination each time a revised version of ASHRAE Standard 90.1 is published with respect to whether the revised standard would improve energy efficiency in commercial buildings. When the U.S. Department of Energy (DOE) issues an affirmative determination on Standard 90.1, states are statutorily required to certify within two years that they have reviewed and updated the commercial provisions of their building energy code, with respect to energy efficiency, to meet or exceed the revised standard.

To meet these statutory requirements, the DOE Building Energy Codes Program (BECP) and Pacific Northwest National Laboratory (PNNL) conduct two types of analysis in a determination of energy savings for a revised Standard 90.1.:

- Qualitative Analysis: This is a detailed textual analysis that identifies all the changes made to the previous edition of Standard 90.1 and categorizes the changes as having a positive, negative, or neutral impact on energy efficiency in commercial buildings. In the qualitative analysis, no attempt is made to estimate a numerical impact using whole building simulation. Three steps are typically undertaken in the qualitative analysis: identify all changes made to Standard 90.1, characterize the impact of each change on the energy efficiency of Standard 90.1, and identify those changes that can be incorporated into the subsequent quantitative analysis.

- Quantitative Analysis: This analysis uses the results of the qualitative analysis to identify which changes should be incorporated into the building simulation models to estimate the energy impact resulting from the changes to Standard 90.1.

This report provides a preliminary quantitative analysis to assess whether buildings constructed according to the requirements of ANSI/ASHRAE/IES Standard 90.1-2013 would result in improved energy efficiency in commercial buildings. The preliminary analysis considered each of the 110 addenda to Standard 90.1-2010 that were included in Standard 90.1-2013. PNNL reviewed all addenda included by ASHRAE in creating Standard 90.1-2013 from Standard 90.1-2010, and considered their combined impact on a suite of prototype building models across all U.S. climate zones. Most addenda were deemed to have little quantifiable impact on building efficiency for the purpose of DOE's preliminary determination. However, out of the 110 total addenda, 30 were identified as having a measureable and quantifiable impact.

The present analysis builds on previous work by PNNL to assess the energy performance of recent editions of Standard 90.1. ${ }^{1}$ A suite of 240 computer energy simulations for prototype buildings complying with Standard 90.1-2010 was developed, a combination of 16 prototype buildings in all15 U.S. climate zones. These prototypes were then modified in accordance with the 30 addenda with quantifiable impacts on energy efficiency to create a second suite of corresponding building simulations reflecting the same buildings complying with Standard 90.1-2013. The building simulations were conducted using the

\footnotetext{
${ }^{1}$ Thornton et al. 2011. Achieving 30\% Goal: Energy and Cost Saving Analysis of ASHRAE/IES Standard 90.12010. Pacific Northwest National Laboratory, Richland, Washington. Available at http://www.energycodes.gov/publications/research/documents/codes/PNNL-20405.pdf.
} 
DOE EnergyPlus Version $8.0^{1}$ building simulation software. The resulting energy use from the complete suite of 480 simulation runs was then converted to energy use intensity (EUI, or energy use per unit floor area) metrics (site EUI, primary EUI), and energy cost intensity (ECI) results for each simulation. For each edition of the standard, these EUIs and ECIs were then aggregated to a national basis for each prototype using weighting factors based on construction floor area developed for each of the 15 U.S. climate zones using commercial construction data (Jarnagin and Bandyopadhyay 2010). When compared, the resulting weighted EUIs indicated that each of the 16 prototype buildings used less energy under Standard 90.1-2013 than under Standard 90.1-2010 on a national basis when considering site energy, primary energy, or energy cost. The EUIs were also aggregated across building types to a national commercial building basis using the same weighting data.

On a national basis, the preliminary quantitative analysis estimated a floor-space-weighted national average reduction in new building energy consumption of $8.5 \%$ for source energy and $7.6 \%$ when considering site energy. An 8.7\% savings in energy cost, based on national average commercial energy costs for electricity and natural gas, was also estimated. National savings results by building type are shown in Figure E-1 and Tables E1, E2, and E3.

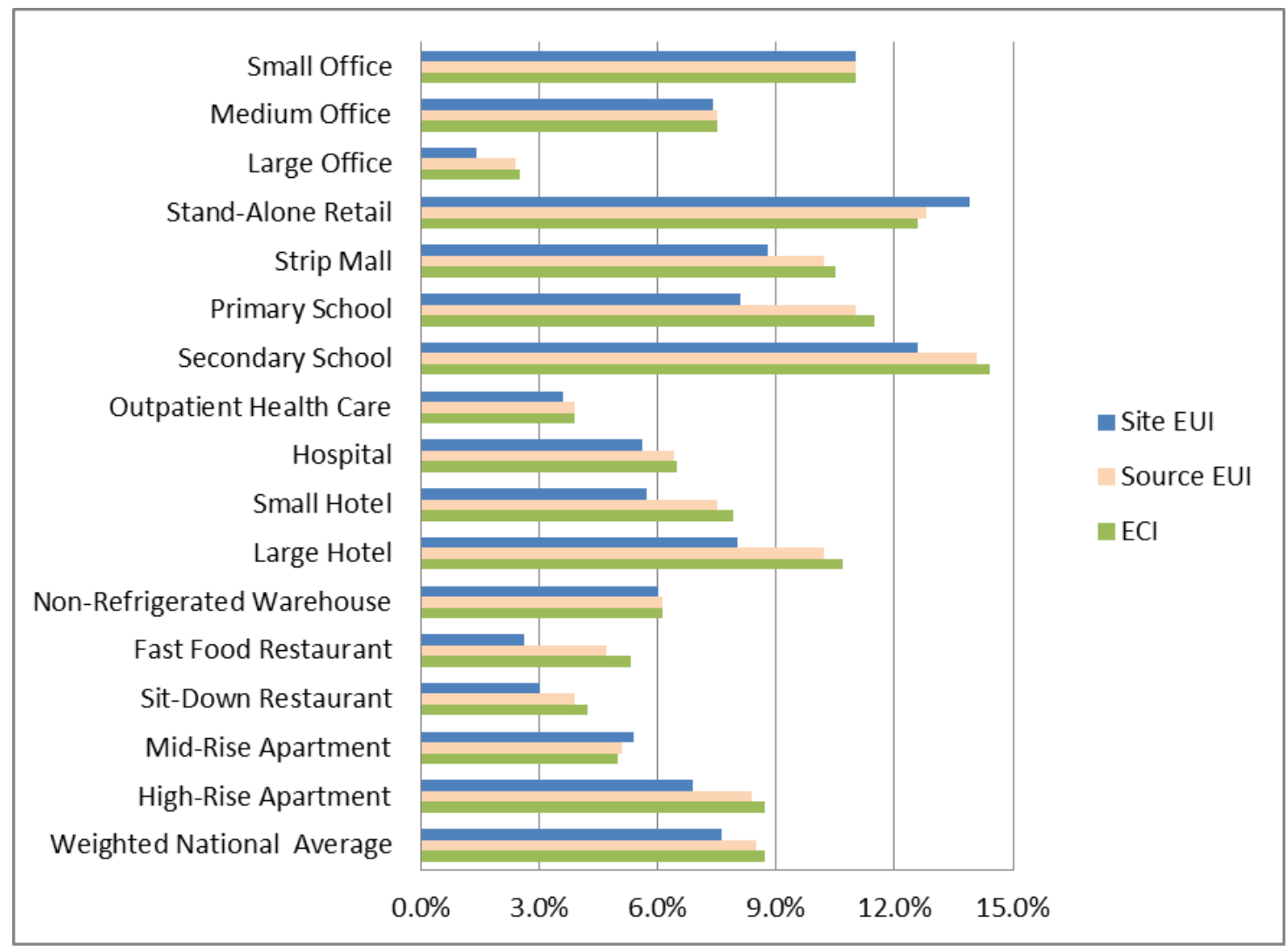

Figure E.1. Percentage Savings by Building Type from 90.1-2010 to 90.1-2013

${ }^{1}$ DOE. 2013. Energy Plus Energy Simulation Software, Version 8.0. U.S. Department of Energy, Washington, D.C. Available at http://apps1.eere.energy.gov/buildings/EnergyPlus/. 
Table E.1. Estimated Energy Use Intensity by Building Type - Standard 90.1-2010

\begin{tabular}{|c|c|c|c|c|c|}
\hline \multirow[b]{2}{*}{$\begin{array}{l}\text { Building } \\
\text { Type }\end{array}$} & \multirow[b]{2}{*}{ Prototype building } & \multirow{2}{*}{$\begin{array}{c}\text { Building } \\
\text { Type Floor } \\
\text { Area Weight } \\
(\%)\end{array}$} & \multicolumn{3}{|c|}{ Whole Building EUI Data for Building Population } \\
\hline & & & $\begin{array}{c}\text { Site EUI } \\
\left(\mathrm{kBtu} / \mathrm{ft}^{2}-\mathrm{yr}\right)\end{array}$ & $\begin{array}{l}\text { Source EUI } \\
\left(\mathrm{kBtu} / \mathrm{ft}^{2}-\mathrm{yr}\right)\end{array}$ & $\begin{array}{c}\text { ECI } \\
\left(\$ / \mathrm{ft}^{2}-\mathrm{yr}\right)\end{array}$ \\
\hline \multirow[t]{3}{*}{ Office } & Small Office & 5.61 & 33.0 & 100.4 & $\$ 0.99$ \\
\hline & Medium Office & 6.05 & 36.8 & 105.9 & $\$ 1.03$ \\
\hline & Large Office & 3.33 & 71.9 & 210.7 & $\$ 2.06$ \\
\hline \multirow[t]{2}{*}{ Retail } & Stand-Alone Retail & 15.25 & 53.4 & 142.9 & $\$ 1.38$ \\
\hline & Strip Mall & 5.67 & 60.4 & 164.1 & $\$ 1.58$ \\
\hline \multirow[t]{2}{*}{ Education } & Primary School & 4.99 & 59.0 & 151.1 & $\$ 1.44$ \\
\hline & Secondary School & 10.36 & 47.7 & 130.3 & $\$ 1.26$ \\
\hline \multirow[t]{2}{*}{ Healthcare } & Outpatient Health Care & 4.37 & 120.0 & 324.3 & $\$ 3.13$ \\
\hline & Hospital & 3.45 & 131.0 & 321.1 & $\$ 3.04$ \\
\hline \multirow[t]{2}{*}{ Lodging } & Small Hotel & 1.72 & 63.6 & 148.8 & $\$ 1.40$ \\
\hline & Large Hotel & 4.95 & 96.7 & 217.7 & $\$ 2.03$ \\
\hline Warehouse & Non-Refrigerated Warehouse & 16.72 & 18.2 & 43.2 & $\$ 0.41$ \\
\hline \multirow{2}{*}{$\begin{array}{l}\text { Food } \\
\text { Service }\end{array}$} & Fast-Food Restaurant & 0.59 & 591.5 & 1051.7 & $\$ 9.27$ \\
\hline & Sit-Down Restaurant & 0.66 & 383.9 & 742.7 & $\$ 6.69$ \\
\hline \multirow[t]{2}{*}{ Apartment } & Mid-Rise Apartment & 7.32 & 46.3 & 131.4 & $\$ 1.28$ \\
\hline & High-Rise Apartment & 8.97 & 50.4 & 124.9 & $\$ 1.19$ \\
\hline National & & 100 & 58.5 & 148.9 & $\$ 1.42$ \\
\hline
\end{tabular}


Table E.2. Estimated Energy Use Intensity by Building Type - Standard 90.1-2013

\begin{tabular}{|c|c|c|c|c|c|}
\hline \multirow[b]{2}{*}{$\begin{array}{l}\text { Building } \\
\text { Type }\end{array}$} & \multirow[b]{2}{*}{ Prototype building } & \multirow{2}{*}{$\begin{array}{c}\text { Building } \\
\text { Type Floor } \\
\text { Area Weight } \\
(\%)\end{array}$} & \multicolumn{3}{|c|}{ Whole Building EUI Data for Building Population } \\
\hline & & & $\begin{array}{c}\text { Site EUI } \\
\left(\mathrm{kBtu} / \mathrm{ft}^{2}-\mathrm{yr}\right)\end{array}$ & $\begin{array}{l}\text { Source EUI } \\
\left(\mathrm{kBtu} / \mathrm{ft}^{2}-\mathrm{yr}\right)\end{array}$ & $\begin{array}{c}\text { ECI } \\
\left(\$ / \mathrm{ft}^{2}-\mathrm{yr}\right)\end{array}$ \\
\hline \multirow[t]{3}{*}{ Office } & Small Office & 5.61 & 29.4 & 89.3 & $\$ 0.88$ \\
\hline & Medium Office & 6.05 & 34.1 & 97.9 & $\$ 0.95$ \\
\hline & Large Office & 3.33 & 70.8 & 205.8 & $\$ 2.01$ \\
\hline \multirow[t]{2}{*}{ Retail } & Stand-Alone Retail & 15.25 & 45.9 & 124.6 & $\$ 1.20$ \\
\hline & Strip Mall & 5.67 & 55.1 & 147.3 & $\$ 1.42$ \\
\hline \multirow[t]{2}{*}{ Education } & Primary School & 4.99 & 54.2 & 134.4 & $\$ 1.28$ \\
\hline & Secondary School & 10.36 & 41.7 & 111.9 & $\$ 1.08$ \\
\hline \multirow[t]{2}{*}{ Healthcare } & Outpatient Health Care & 4.37 & 115.8 & 311.8 & $\$ 3.00$ \\
\hline & Hospital & 3.45 & 123.7 & 300.7 & $\$ 2.85$ \\
\hline \multirow[t]{2}{*}{ Lodging } & Small Hotel & 1.72 & 60.0 & 137.6 & $\$ 1.29$ \\
\hline & Large Hotel & 4.95 & 89.0 & 195.4 & $\$ 1.81$ \\
\hline Warehouse & $\begin{array}{l}\text { Non-Refrigerated } \\
\text { Warehouse }\end{array}$ & 16.72 & 17.1 & 40.6 & $\$ 0.38$ \\
\hline \multirow{2}{*}{$\begin{array}{l}\text { Food } \\
\text { Service }\end{array}$} & Fast-Food Restaurant & 0.59 & 576.4 & 1001.9 & $\$ 8.78$ \\
\hline & Sit-Down Restaurant & 0.66 & 372.5 & 713.5 & $\$ 6.41$ \\
\hline \multirow[t]{2}{*}{ Apartment } & Mid-Rise Apartment & 7.32 & 43.9 & 124.8 & $\$ 1.21$ \\
\hline & High-Rise Apartment & 8.97 & 46.9 & 114.4 & $\$ 1.08$ \\
\hline National & & 100 & 54.1 & 136.2 & $\$ 1.30$ \\
\hline
\end{tabular}


Table E.3. Estimated Percent Energy Savings between 2010 and 2013 Editions of Standard 90.1 - by Building Type

\begin{tabular}{|c|c|c|c|c|c|}
\hline \multirow[b]{2}{*}{ Building Type } & \multirow[b]{2}{*}{ Prototype building } & \multirow{2}{*}{$\begin{array}{l}\text { Building Type } \\
\text { Floor Area } \\
\text { Weight } \\
\text { (\%) }\end{array}$} & \multicolumn{3}{|c|}{$\begin{array}{c}\text { Percent Savings in Whole Building } \\
\text { Energy Use Intensity } \\
\text { (\%) }\end{array}$} \\
\hline & & & Site EUI & Source EUI & ECI \\
\hline \multirow[t]{3}{*}{ Office } & Small Office & 5.61 & 11.0 & 11.0 & 11.0 \\
\hline & Medium Office & 6.05 & 7.4 & 7.5 & 7.5 \\
\hline & Large Office & 3.33 & 1.4 & 2.4 & 2.5 \\
\hline \multirow[t]{2}{*}{ Retail } & Stand-Alone Retail & 15.25 & 13.9 & 12.8 & 12.6 \\
\hline & Strip Mall & 5.67 & 8.8 & 10.2 & 10.5 \\
\hline \multirow[t]{2}{*}{ Education } & Primary School & 4.99 & 8.1 & 11.0 & 11.5 \\
\hline & Secondary School & 10.36 & 12.6 & 14.1 & 14.4 \\
\hline \multirow[t]{2}{*}{ Healthcare } & Outpatient Health Care & 4.37 & 3.6 & 3.9 & 3.9 \\
\hline & Hospital & 3.45 & 5.6 & 6.4 & 6.5 \\
\hline \multirow[t]{2}{*}{ Lodging } & Small Hotel & 1.72 & 5.7 & 7.5 & 7.9 \\
\hline & Large Hotel & 4.95 & 8.0 & 10.2 & 10.7 \\
\hline Warehouse & Non-Refrigerated Warehouse & 16.72 & 6.0 & 6.1 & 6.1 \\
\hline \multirow[t]{2}{*}{ Food Service } & Fast Food Restaurant & 0.59 & 2.6 & 4.7 & 5.3 \\
\hline & Sit-Down Restaurant & 0.66 & 3.0 & 3.9 & 4.2 \\
\hline \multirow[t]{2}{*}{ Apartment } & Mid-Rise Apartment & 7.32 & 5.4 & 5.1 & 5.0 \\
\hline & High-Rise Apartment & 8.97 & 6.9 & 8.4 & 8.7 \\
\hline National & & 100 & 7.6 & 8.5 & 8.7 \\
\hline
\end{tabular}





\section{Acronyms and Abbreviations}

\begin{tabular}{|c|c|}
\hline AEDG & Advanced Energy Design Guide \\
\hline AEO & Annual Energy Outlook \\
\hline AFUE & annual fuel utilization efficiency \\
\hline AHRI & Air-Conditioning, Heating, and Refrigeration Institute \\
\hline AHU & air handling unit \\
\hline AMCA & Air Movement and Control Association \\
\hline ANSI & American National Standards Institute \\
\hline ASHRAE & American Society of Heating, Refrigerating, and Air-Conditioning Engineers \\
\hline bhp & brake horsepower \\
\hline BECP & Building Energy Codes Program \\
\hline Btu & British thermal unit(s) \\
\hline $\mathrm{Btu} / \mathrm{h}$ & British thermal unit(s) per hour \\
\hline $\mathrm{Btu} / \mathrm{kWh}$ & British thermal unit per kilowatt-hour \\
\hline CBECS & Commercial Building Energy Consumption Survey \\
\hline COP & coefficient of performance \\
\hline CRRC & Cool Roof Rating Council \\
\hline $\mathrm{CZ}$ & climate zone \\
\hline DCV & demand-controlled ventilation \\
\hline DDC & direct digital control(s) \\
\hline DOE & U.S. Department of Energy \\
\hline DX & direct expansion \\
\hline $\mathrm{E}_{\mathrm{c}}$ & combustion efficiency \\
\hline EC & electronically commutated \\
\hline ECB & energy cost budget \\
\hline ECI & energy cost intensity \\
\hline ECPA & Energy Conservation and Production Act \\
\hline EER & energy efficiency ratio \\
\hline EIA & Energy Information Administration \\
\hline EMS & energy management system \\
\hline EPAct & Energy Policy Act \\
\hline EPCA & Energy Policy and Conservation Act \\
\hline ER & emergency room \\
\hline ERV & energy recovery ventilator \\
\hline $\mathrm{E}_{\mathrm{t}}$ & thermal efficiency \\
\hline EUI & energy use intensity \\
\hline hp & horsepower \\
\hline
\end{tabular}


HSPF

HVAC

ICU

IEAD

IEER

IES

kBtu

$\mathrm{kWh}$

LABS

LPD

MAT

$\mathrm{MBH}$

NC3

NEMA

NFRC

OR

PATRMS

PBA

PBAplus

PLR

PNNL

PSC

PTAC

PTHP

$\mathrm{RH}$

SAT

SEER

SHGC

SPVAC

SPVHP

VAV

VT

w.c. heating seasonal performance factor

heating, ventilation, and air-conditioning

intensive care unit

insulation entirely above deck

integrated energy efficiency ratio

Illuminating Engineering Society of North America

thousand British thermal unit(s)

kilowatt hour(s)

laboratories

lighting power density

mixed air temperature

thousand Btu per hour

New Commercial Construction Characteristics database

National Electrical Manufacturers Association

National Fenestration Rating Council

operating room

patient rooms

principal building activity

detailed principal building activity

part load ratio

Pacific Northwest National Laboratory

permanent-split capacitor

packaged terminal air conditioner

packaged terminal heat pump

relative humidity

supply air temperature

seasonal energy efficiency ratio

solar heat gain coefficient

single package vertical air conditioners

single package vertical heat pumps

variable air volume

visible transmittance

water column 


\section{Contents}

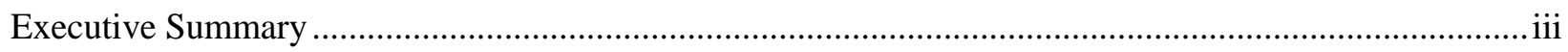

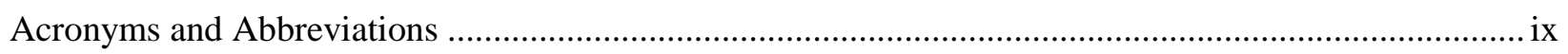

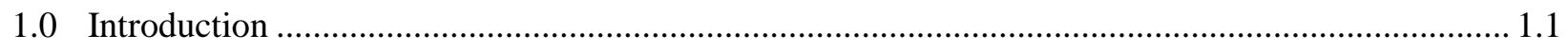

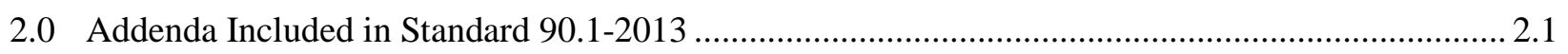

3.0 Prototype Buildings and Simulation Methodology ................................................................ 3.1

3.1 Building Types and Model Prototypes ................................................................................ 3.1

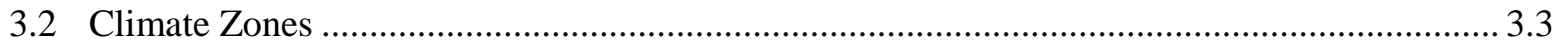

3.3 Development of Weighting Factors and National Savings Estimates .................................... 3.5

4.0 Inclusion of Addenda in the Quantitative Analysis ..................................................................... 4.1

5.0 Modeling of Specific Addenda .............................................................................................. 5.1

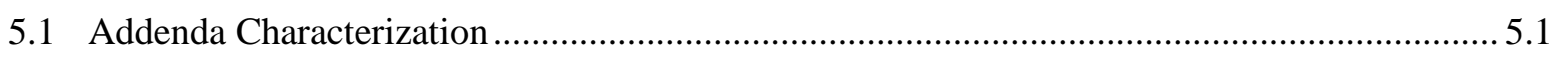

5.2 Addenda Implementation in Modeling............................................................................ 5.2

5.2 .1 Building Envelope............................................................................................... 5.2

5.2.2 Heating, Ventilating, and Air-Conditioning........................................................... 5.5

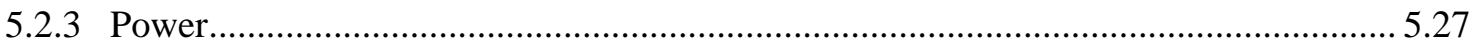

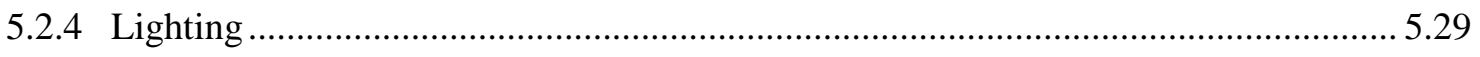

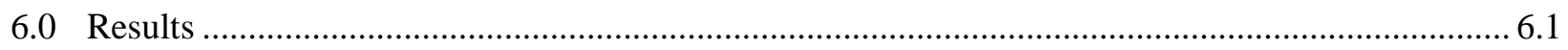

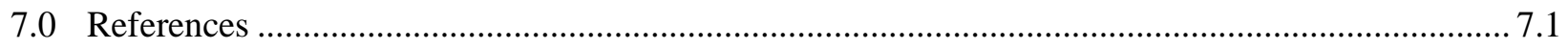

Appendix A . Addenda Processed for ANSI/ASHRAE/IES Standard 90.1-2013 .................................. A.1

Appendix B . Addenda Included in Quantitative Analysis and their Impact on Prototype

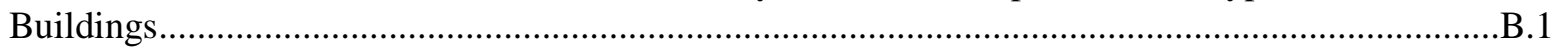

Appendix C . Comparison of Building Envelope Requirements in Standard 90.1-2010 and

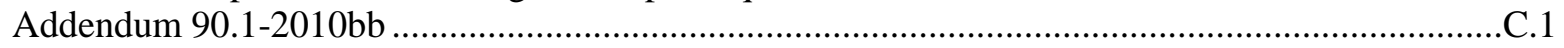

Appendix D . Impact of the DOE Determination on State and Local Government............................... D.1

\section{Tables}

Table E.1. Estimated Energy Use Intensity by Building Type - Standard 90.1-2010 ...............................

Table E.2. Estimated Energy Use Intensity by Building Type - Standard 90.1-2013 ...............................vi

Table E.3. Estimated Percent Energy Savings between 2010 and 2013 Editions of Standard 90.1

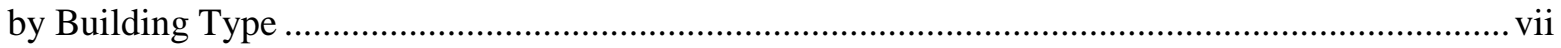

Table 3.1. ASHRAE Commercial Prototype Building Models ............................................................ 3.2

Table 3.2. Relative Construction Volume Weights for 16 Prototype buildings by Climate Zone............ 3.6

Table 5.1. Addenda with Quantified Energy Impacts.............................................................................. 5.2

Table 5.2. New SHGC Values Meeting Addendum 90.1-2010bw Fenestration Orientation

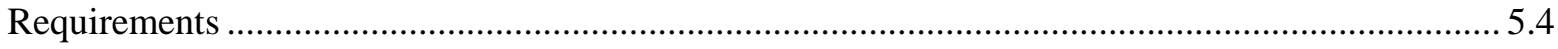


Table 5.3. Typical number of Commercial Refrigerators and Freezers in Prototype Models

Table 5.4. Summary of Energy Use Limits for Commercial Refrigerators and Freezers in

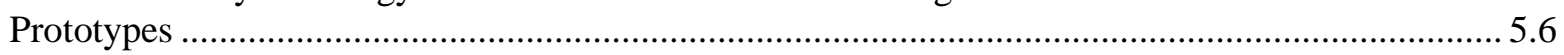

Table 5.5. Impacted Equipment and Efficiency Changes Required by Addendum 90.1-2010h .............. 5.7

Table 5.6. Prototype buildings Affected by Addendum 90.1-2010aj ................................................. 5.9

Table 5.7. Baseline and Advanced Fan Assumptions for Different Fan Systems ................................ 5.10

Table 5.8. Boiler Turndown Required by Addendum 90.1-2010am ................................................... 5.10

Table 5.9. Prototype Building Properties and Assumptions for Modeling Door Switches.................... 5.17

Table 5.10. Unitary HVAC Equipment Efficiency (<65,000 Btu/h) ................................................ 5.18

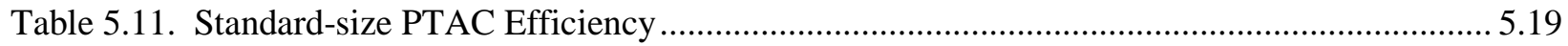

Table 5.12. New ERV Requirements for Ventilation Systems Operating Less than 8000 Hours

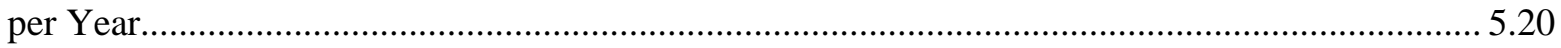

Table 5.13 ERV Requirements for Ventilation Systems Operating Greater than 8,000 Hours per

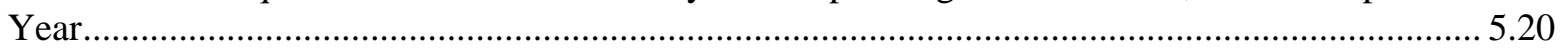

Table 5.14. Systems in Prototype building Models Requiring DDC and Setback Controls in

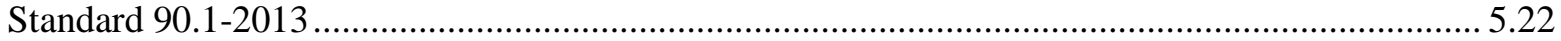

Table 5.15. Efficiency in COP for Chillers....................................................................................... 5.24

Table 5.16. Boiler Efficiency Requirements in Addendum 90.1-2010cz ............................................ 5.25

Table 5.17. Area Fractions for Space Types Added by Addendum 90.1-2010bf .................................. 5.28

Table 5.18. Factors Used to Calculate Reduction Fraction for Equipment Schedule............................ 5.28

Table 5.19. Reduction Factors for Baseline and Advanced Models ................................................... 5.29

Table 5.20. Fraction of Lighting Power Controlled by Daylighting Sensors in Zones in Prototype

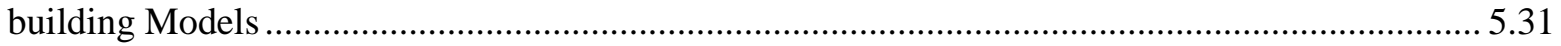

Table 5.21. Fraction of Each Perimeter Zone under Daylighting Control in Office Prototype

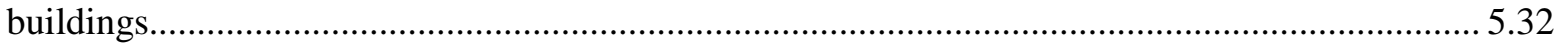

Table 5.22. Combined Impact of Addenda 90.1-2010bh, 90.1-2010cr, 90.1-2010dj, and 90.12010dl on Spaces Affected in Simulation Analysis..................................................................... 5.34

Table 5.23. Lighting Control Reduction Fraction for Space Types ..................................................... 5.36

Table 5.24. Impact of Addendum 90.1-2010co on Prototypes .......................................................... 5.37

Table 6.1. Estimated Energy Use Intensity by Building Type - Standard 90.1-2010 ........................... 6.1

Table 6.2. Estimated Energy Use Intensity by Building Type - Standard 90.1-2013 ........................... 6.2

Table 6.3. Estimated Percent Energy Savings between 2010 and 2013 Editions of Standard 90.1

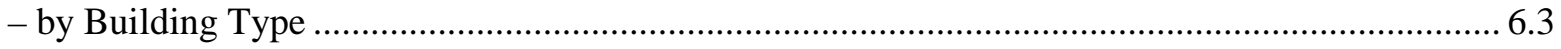




\section{Figures}

Figure E.1. Percentage Savings by Building Type from 90.1-2010 to 2013.........................iv

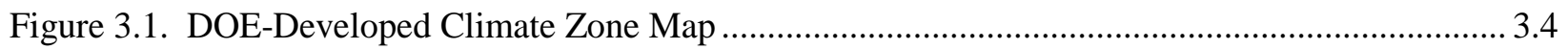

Figure 5.1. Addenda by Category and Quantity ............................................................................... 5.1

Figure 5.2. Heating Setpoints for Vestibule Zone in the Standalone Retail Prototype Building.............. 5.5

Figure 5.3. Example of Optimum Start Control Operation for a Warm Morning ................................ 5.23

Figure 6.1. Percentage Savings by Building Type from 90.1-2010 to 90.1-2013 ................................... 6.4 


\subsection{Introduction}

Title III of the Energy Policy and Conservation Act, as amended (EPCA), establishes requirements for the Building Energy Efficiency Standards Program (42 U.S.C. 6831 et seq.). Section 304(b), as amended, of EPCA provides that whenever the ANSI/ASHRAE/IESNA ${ }^{1}$ 90.1-1989 (Standard 90.1-1989 or 1989 edition), or any successor to that code, is revised, the Secretary must make a determination, not later than 12 months after such revision, whether the revised code would improve energy efficiency in commercial buildings and must publish notice of such determination in the Federal Register (42 U.S.C. 6833 (b)(2)(A)). The Secretary may determine that the revision of Standard 90.1-1989, or any successor thereof, improves the level of energy efficiency in commercial buildings. If so, then not later than 2 years after the date of the publication of such affirmative determination, each State is required to certify that it has reviewed and updated the provisions of its commercial building code regarding energy efficiency with respect to the revised or successor code (42 U.S.C. 6833(b)(2)(B)(i)). The State must include in its certification a demonstration that the provisions of its commercial building code, regarding energy efficiency, meet or exceed the revised standard (42 U.S.C. 6833(b)(2)(B)(i)).

If the Secretary makes a determination that the revised standard will not improve energy efficiency in commercial buildings, State commercial codes shall meet or exceed the last revised standard for which the Secretary has made a positive determination (42 U.S.C. 6833(b)(2)(B)(ii)). EPCA also requires the Secretary to permit extensions of the deadlines for the State certification if a State can demonstrate that it has made a good faith effort to comply with the requirements of Section 304(c) of EPCA and that it has made significant progress in doing so (42 U.S.C. 6833(c)).

On October 9, 2011, DOE issued a final positive determination of energy savings for Standard 90.12010, which concluded that Standard 90.1-2010 would achieve greater energy efficiency in buildings subject to the code, than Standard 90.1-2007. (76 FR 64904). Consequently, DOE has determined that Standard 90.1-2010 represents the baseline to which Standard 90.1-2013 requirements are compared for the purpose of a determination of energy savings for Standard 90.1-2013.To meet these statutory requirements, the DOE Building Energy Codes Program (BECP) and Pacific Northwest National Laboratory (PNNL) conduct two types of analysis in a determination of energy savings for a revised Standard $90.1^{2}$ :

- Qualitative Analysis: This is a detailed textual analysis that identifies all the changes made to the previous edition of Standard 90.1 and categorizes the changes as having a positive, negative, or neutral impact on energy efficiency in commercial buildings. In the qualitative analysis, no attempt is made to estimate a numerical impact using whole building simulation. Three steps are typically undertaken in the qualitative analysis: identify all changes made to Standard 90.1, characterize the impact of each change on the energy efficiency of Standard 90.1, and identify those changes that can be incorporated into the subsequent quantitative analysis.

- Quantitative Analysis: This analysis uses the results of the qualitative analysis to identify which changes should be incorporated into the building simulation models to estimate the energy impact resulting from the changes to Standard 90.1.

\footnotetext{
${ }^{1}$ American National Standards Institute/American Society of Heating, Refrigerating, and Air Conditioning Engineers/Illuminating Engineering Society of North America

${ }^{2}$ Standard 90.1-2010 Determination available at http://www.energycodes.gov/regulations/determinations
} 
In support of the U.S. Department of Energy's (DOE's) preliminary determination of energy savings of ANSI/ASHRAE/IES ${ }^{1}$ Standard 90.1-2013 (referred to as ASHRAE Standard 90.1-2013, Standard 90.1-2013, 90.1-2013, or 2013 edition) (ASHRAE 2013b), Pacific Northwest National Laboratory (PNNL) prepared this preliminary quantitative assessment of the relative energy use for commercial buildings designed to meet requirements found in Standard 90.1-2013 compared to meeting requirements found in ANSI/ASHRAE/IES Standard 90.1-2010 (referred to as ASHRAE Standard 90.1-2010, Standard 90.1-2010, 90.1-2010, or 2010 edition) (ASHRAE 2010b).

This evaluation is carried out using computer simulations of prototype buildings constructed to Standard 90.1-2010 and Standard 90.1-2013 across the range of U.S. climates. Each prototype building used in the simulation analysis was first developed as a computer model in accordance with design and construction requirements found in Standard 90.1-2010. Changes to the building model, consistent with addenda published to Standard 90.1-2010 in the development of Standard 90.1-2013, are made to reflect the building as it would be constructed under the requirements of Standard 90.1-2013. The set of Standard 90.1-2010 and Standard 90.1-2013 buildings are simulated, and energy use statistics are extracted from each building model in the form of annual energy use by energy type. The annual energy use is then converted to energy use intensity (EUI) figures expressed in annual energy use per square foot. Using weighting factors by building type and geographic area developed using the past 5 years of construction data, these energy use results are then aggregated to national levels for each revision of Standard 90.1. DOE relies upon these data and analysis to assess whether an affirmative determination can be made for Standard 90.1-2013.

The ensuing sections of this document describe:

- determination process,

- characterization of the addenda to be modeled for Standard 90.1-2013,

- characterization of the building models,

- simulation methodology,

- use of building construction weights to aggregate results from simulations across building types and locations into national results,

- translation of the addenda into modeling inputs used in the computer simulations, and

- results of the analysis with regard to the overall EUI for buildings under both standards and the energy and energy cost savings of Standard 90.1-2013 over Standard 90.1-2010.

Review Under the Information Quality Act

This report is being disseminated by the Department of Energy. As such, the document was prepared in compliance with Section 515 of the Treasury and General Government Appropriations Act for Fiscal Year 2001 (Public Law 106-554) and information quality guidelines issued by the Department of

\footnotetext{
${ }^{1}$ American National Standards Institute/American Society of Heating, Refrigerating, and Air Conditioning Engineers/Illuminating Engineering Society of North America
} 
Energy. Though this report does not constitute “influential” information, as that term is defined in DOE's information quality guidelines or the Office of Management and Budget's Information Quality Bulletin for Peer Review (Bulletin), the current report builds upon methods of analysis that have been subjected to peer review and public dissemination. In addition, this work has been subject to internal peer review and will be subject to external peer review through the public comment process as part of DOE's Preliminary Determination for Standard 90.1-2013. 


\subsection{Addenda Included in Standard 90.1-2013}

PNNL prepared a qualitative assessment of the addenda to Standard 90.1-2010 that were included in Standard 90.1-2013 in support of a preliminary assessment of energy savings (Halverson et al. 2014). Standard 90.1-2013 incorporates Standard 90.1-2010 and all approved addenda. Appendix A lists all 110 addenda processed by ASHRAE for inclusion in Standard 90.1-2013. The addenda included in Standard 90.1-2013 may also be found in the published supplements to Standard 90.1-2010 on the ASHRAE website (ASHRAE 2012, ASHRAE 2013a).

The list of addenda in Appendix A of this report is taken from Appendix F to Standard 90.1-2013. Appendix A lists each addendum and describes the way in which the text is affected by the change, as well as ASHRAE, IES, and ANSI approval dates. Appendix A is a copy of Appendix F to Standard 90.12013 with minor edits to define some of the acronyms used in Appendix F and to make the format of the descriptions the same. The description of addendum 90.1-2010j was also modified in this report as it was a repeat of the description of addendum 90.1-2010k. The section affected by addendum 90.1-2010bo was also modified to indicate that this addendum is associated with the Service Water Heating section and not the Heating, Ventilating, and Air-Conditioning section.

Note that the table numbers called out in Appendix A refer to Standard 90.1-2010. In Standard 90.12013, tables have been renumbered from a format of "Table (Section Number) Letter" to "(Table Section Number)-Number.” Thus, for example, Table 6.8.1A in Standard 90.1-2010 is now Table 6.8.1-1 in Standard 90.1-2013. Notes have been added to the discussion throughout this report to show both the original Standard 90.1-2010 table numbers and the Standard 90.1-2013 table numbers.

ASHRAE Standard 90.1-2013 includes addenda that:

- are purely editorial or update references to other documents,

- update prescriptive design and construction requirements for the envelope, lighting, mechanical, power, and other equipment sections of the standard,

- update the performance path option to compliance (the energy cost budget and performance rating method sections of Standard 90.1 [Appendix G]), or

- affect informative appendix material that is provided in Standard 90.1-2013 but is not part of the design and construction requirements of the standard.

For the quantitative analysis, PNNL includes in the analysis only those addenda that modified the prescriptive and mandatory requirements of Standard 90.1. In specific circumstances, particularly with regard to requirements for certain heating, ventilation, and air-conditioning (HVAC) equipment, addenda to Standard 90.1-2010 reflect changes to national manufacturing standards previously developed by DOE or enacted independently through federal legislation. Because the energy savings that are attributable to these national manufacturing standards would accrue no matter what edition of Standard 90.1 is complied with and regardless of whether they are reflected in the text of the standards, PNNL has not incorporated these as changes contributing to energy savings for the purpose of the determination. 


\subsection{Prototype Buildings and Simulation Methodology}

The purpose of the preliminary quantitative analysis described here is to provide DOE with an evaluation of the relative energy efficiency of ASHRAE Standard 90.1-2010 and Standard 90.1-2013 when taken as a whole. To the degree that it can be considered representative of all commercial building construction, the preliminary analysis estimates the impact of the change in standards on commercial building energy efficiency. The quantitative comparison of energy codes is based on whole building energy simulation of buildings whose characteristics match either Standard 90.1-2010 or Standard 90.12013. It is not feasible to simulate all possible permutations of building design. Further, data are simply not available to correctly weigh each possible permutation in each U.S. climate zone as a fraction of the national building construction mix. Hence, the quantitative analysis focuses on the use of prototype buildings that reflect a representative mix of typical construction practices.

The present analysis builds on previous work conducted by PNNL to assess the energy performance of the three most recent editions of Standard 90.1 in (Thornton et al. 2011), referred to here as Analysis of 90.1-2010. The individual building models for each climate are modified as needed to correctly reflect the prescriptive requirements for Standard 90.1-2010 as required for each climate zone. In addition, for each of these Standard 90.1-2010 compliant building models, a second, corresponding building with the same basic design and use patterns, but which reflects the prescriptive requirements of Standard 90.12013, is developed. This process is completed by reviewing each addendum; first establishing whether that addendum would affect a given prototype building (based on the assumptions and descriptions of the prototype building components) and in which climates.

Each of the 480 building models (16 prototypes, 15 climate locations, and two standards) is simulated using EnergyPlus Version 8.0 (DOE 2013), and the resulting energy use is extracted by energy type and by end use. The energy use data is then aggregated by energy type and, using the floor space for each prototype, converted to EUI metrics for each energy type by prototype building by climate and standard edition.

\subsection{Building Types and Model Prototypes}

Sixteen prototype buildings are shown in Table 3.1 and used in the preliminary quantitative analysis. Each prototype building model is defined as characteristic of a certain class of buildings, mostly corresponding to a classification scheme established in the 2003 DOE/Energy Information Administration (EIA) Commercial Building Energy Consumption Survey (CBECS) (EIA 2003). CBECS categorizes commercial buildings using the two variables "variable principal building activity" (PBA) and "detailed principal building activity” (PBAplus) for more specific activities, separating the commercial sector into 29 PBA categories and 51 subcategories. PNNL relied heavily on these classifications in determining the buildings to be represented by the set of prototype building models. By mapping CBECS observations to each prototype building, PNNL also used the CBECS building characteristics data to develop prototypes that could best typify the building stock.

Multi-family housing buildings are not included in CBECS but are covered by Standard 90.1, if more than three stories high. Consequently, PNNL developed mid-rise and high-rise multi-family prototype building to add to the original prototype buildings identified through the review of CBECS. The 
characteristics of the mid-rise and high-rise multi-family buildings were developed from data in a separate study by PNNL (Gowri et al. 2007).

Details on the development of all the prototype buildings that are used in this analysis may be found in the technical support document for the Analysis of 90.1-2010 (Thornton et al. 2011). The prototype models described in that report have since been modified as described in the document Enhancements to ASHRAE Standard 90.1 Prototype Building Models (PNNL 2014). This document is available at https://www.energycodes.gov/development/commercial/90.1_models.

Table 3.1. ASHRAE Commercial Prototype Building Models

\begin{tabular}{lcc}
\hline Building Type & Prototype \\
\hline Office & Small Office & $\begin{array}{c}\text { Floor Area } \\
\left(\mathrm{ft}^{2}\right)\end{array}$ \\
\hline Retail & Medium Office & 5,502 \\
& Large Office & 53,628 \\
\hline Education & Stand-Alone Retail & 498,588 \\
\hline Healthcare & Strip Mall & 24,692 \\
\hline Lodging & Primary School & 22,500 \\
\hline Warehouse & Secondary School & 73,959 \\
\hline Food Service & Outpatient Health Care & 210,887 \\
\hline Apartment & Hospital & 240,946 \\
\hline & Small Hotel & 43,202 \\
\hline
\end{tabular}

In the case of office buildings, one of the largest PBA categories in terms of floor area out of the total stock, PNNL determined that the wide variation in building design and equipment use made determining a "typical" office design difficult. Consequently, PNNL developed three sizes and form factors characteristic of small, medium, and large office buildings to reflect the wide variation in office building design. Similarly, retail, education, healthcare, lodging, food service, and apartments have two representative prototypes each.

To keep the building set manageable, the basic form factor and equipment selection for each prototype building was developed to be most typical of construction on a national basis. Regional variations in form factor, size, or design differences such as equipment selection are not represented in the group of prototype buildings.

The 16 prototypes used in the preliminary quantitative analysis together reflect approximately $80 \%$ of the total square footage of commercial construction, including multi-family buildings more than three stories tall, covered under ASHRAE Standard 90.1 (Jarnagin and Bandyopadhyay 2010). 


\subsection{Climate Zones}

Standardized climate zones originally developed by DOE are used for the preliminary determination analysis. These climate zones have since been adopted by the International Energy Code Council as well as ASHRAE for both residential and commercial building applications. The common set of climate zones includes eight thermal zones covering the entire United States, as shown in Figure 3.1 (Briggs et al. 2003). Climate zones are categorized from 1 to 8 , with increasing heating degree days and decreasing cooling degree days. These thermal climate zones may be mapped to other climate locations for international use. Most thermal climate zones are further divided into moist (A), dry (B), and marine (C) regions. For this analysis, a specific climate location (city) is selected as a representative of each climate zone. A set of 15 cities is used that represents the 15 climate zones identified in Standard 90.1 that exist in the United States. Two other climate zones are identified by ASHRAE but are not included because the climate subzones they represent do not exist in the U.S. Riyadh, Saudi Arabia represents climate zone 1B (very hot, dry) and Vancouver B.C., Canada represents climate zone 5C (cool, marine).

The 15 cities representing the climate zones are:

- 1A: Miami, Florida (very hot, humid)

- 2A: Houston, Texas (hot, humid)

- 2B: Phoenix, Arizona (hot, dry)

- 3A: Memphis, Tennessee (warm, humid)

- 3B: El Paso, Texas (warm, dry)

- 3C: San Francisco, California (warm, marine)

- 4A: Baltimore, Maryland (mixed, humid)

- 4B: Albuquerque, New Mexico (mixed, dry)
- 4C: Salem, Oregon (mixed, marine)

- 5A: Chicago, Illinois (cool, humid)

- 5B: Boise, Idaho (cool, dry)

- 6A: Burlington, Vermont (cold, humid)

- 6B: Helena, Montana (cold, dry)

- 7: Duluth, Minnesota (very cold)

- 8: Fairbanks, Alaska (subarctic) 


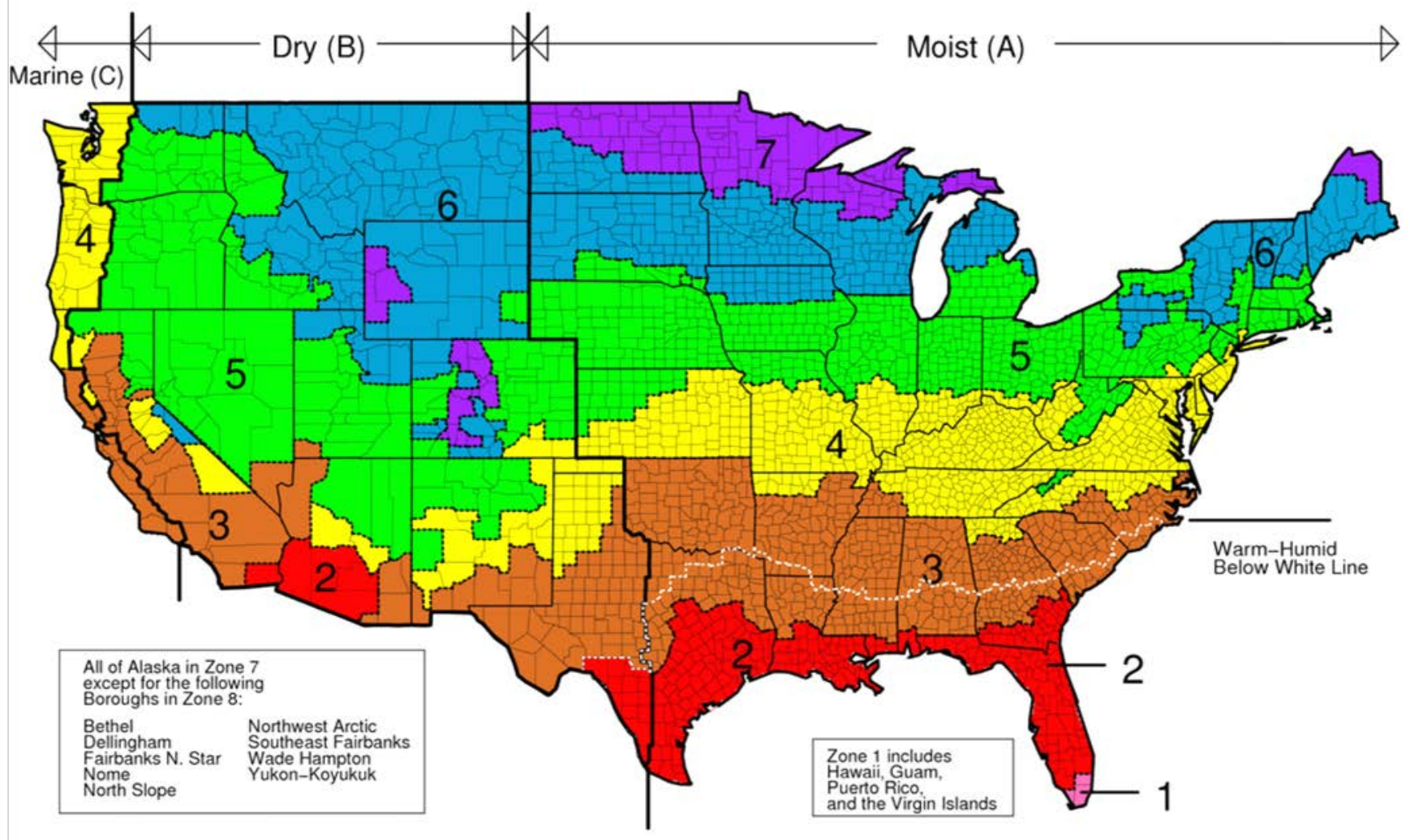

Figure 3.1. DOE-Developed Climate Zone Map 


\subsection{Development of Weighting Factors and National Savings Estimates}

Weighting factors were developed based on 5 years' of construction data purchased from McGraw Hill's construction data set. Development of the weighting factors is discussed in a PNNL report (Jarnagin and Bandyopadhyay 2010), which details weighting factors for 16 prototype buildings, including the high-rise apartment commercial prototype building. Table 3.2 lists the resulting weighting factors by climate and by prototype building in the preliminary determination.

PNNL developed estimates of the new construction floor space that correspond to each prototype/climate zone combination. These data are used to develop the relative fractions of new construction floor space represented by prototype building and within the 15 climate zones. Using the energy use index (EUI) statistics from each building simulation and the corresponding relative fractions of new construction floor space, PNNL developed floor-space-weighted national EUI statistics by energy type for each building type and standard level. PNNL then added these energy-specific EUI estimates to obtain the national site energy EUI by building type and standard level. PNNL also applied national data for average energy prices and average primary energy conversion rates to the energy-specific EUI data to obtain estimates of national primary energy EUI and national energy cost intensity (ECI), again by building type and by standard level. PNNL examined the national results by prototype building to determine which building types would show reduced energy use under Standard 90.1-2013.

Finally, PNNL weighted the EUI and ECI statistics by building type to arrive at national site EUI, primary energy EUI, and ECI values for buildings constructed under both editions of Standard 90.1. The approach taken is not comprehensive for all buildings. The analysis assesses the relative energy impact of the standard by simulating prototypical examples of buildings of various types reflected in the overall building population. It is recognized that some specific requirements of the standard will not be amenable to simulation within the scope of this analysis. For most of these requirements, any differences in requirements will suggest an obvious stringency change between the standards, and this has been explored in the qualitative analysis done in parallel to this quantitative assessment (Halverson et al. 2014). 
Table 3.2. Relative Construction Volume Weights for 16 Prototype buildings by Climate Zone

\begin{tabular}{|c|c|c|c|c|c|c|c|c|c|c|c|c|c|c|c|c|}
\hline Building Type & 1 & $2 \mathrm{~A}$ & 2B & $3 \mathrm{~A}$ & 3B & $3 C$ & $4 \mathrm{~A}$ & $4 \mathrm{~B}$ & $4 \mathrm{C}$ & $5 \mathrm{~A}$ & $5 B$ & $6 \mathrm{~A}$ & $6 \mathrm{~B}$ & 7 & 8 & $\begin{array}{c}\text { Weights } \\
\text { by Bldg } \\
\text { Type }\end{array}$ \\
\hline Large office & 0.102 & 0.326 & 0.061 & 0.445 & 0.285 & 0.117 & 1.132 & 0.000 & 0.154 & 0.442 & 0.121 & 0.133 & 0.000 & 0.011 & 0.000 & 3.33 \\
\hline Medium office & 0.129 & 0.813 & 0.292 & 0.766 & 0.715 & 0.136 & 1.190 & 0.036 & 0.196 & 1.060 & 0.342 & 0.298 & 0.035 & 0.033 & 0.007 & 6.05 \\
\hline Small office & 0.084 & 1.064 & 0.289 & 0.963 & 0.475 & 0.078 & 0.936 & 0.047 & 0.123 & 0.920 & 0.322 & 0.241 & 0.030 & 0.032 & 0.005 & 5.61 \\
\hline Standalone retail & 0.224 & 2.220 & 0.507 & 2.386 & 1.250 & 0.191 & 2.545 & 0.119 & 0.428 & 3.429 & 0.792 & 0.948 & 0.091 & 0.109 & 0.014 & 15.25 \\
\hline Strip mall retail & 0.137 & 0.991 & 0.254 & 1.021 & 0.626 & 0.103 & 1.008 & 0.023 & 0.107 & 1.023 & 0.201 & 0.153 & 0.016 & 0.007 & 0.001 & 5.67 \\
\hline Primary school & 0.064 & 0.933 & 0.164 & 0.944 & 0.446 & 0.048 & 0.895 & 0.030 & 0.094 & 0.920 & 0.224 & 0.168 & 0.037 & 0.023 & 0.003 & 4.99 \\
\hline Secondary school & 0.160 & 1.523 & 0.230 & 1.893 & 0.819 & 0.109 & 2.013 & 0.063 & 0.243 & 2.282 & 0.438 & 0.415 & 0.086 & 0.075 & 0.012 & 10.36 \\
\hline Hospital & 0.040 & 0.479 & 0.096 & 0.468 & 0.273 & 0.039 & 0.615 & 0.022 & 0.106 & 0.812 & 0.218 & 0.221 & 0.024 & 0.034 & 0.001 & 3.45 \\
\hline $\begin{array}{l}\text { Outpatient } \\
\text { health care }\end{array}$ & 0.037 & 0.567 & 0.134 & 0.581 & 0.275 & 0.061 & 0.818 & 0.023 & 0.181 & 1.058 & 0.218 & 0.342 & 0.033 & 0.039 & 0.002 & 4.37 \\
\hline $\begin{array}{l}\text { Full-service } \\
\text { restaurant }\end{array}$ & 0.009 & 0.106 & 0.025 & 0.111 & 0.047 & 0.006 & 0.127 & 0.006 & 0.010 & 0.143 & 0.031 & 0.031 & 0.004 & 0.004 & 0.000 & 0.66 \\
\hline $\begin{array}{l}\text { Quick-service } \\
\text { restaurant }\end{array}$ & 0.008 & 0.092 & 0.020 & 0.102 & 0.063 & 0.007 & 0.089 & 0.005 & 0.014 & 0.128 & 0.026 & 0.025 & 0.003 & 0.004 & 0.000 & 0.59 \\
\hline Large hotel & 0.109 & 0.621 & 0.125 & 0.635 & 0.793 & 0.106 & 0.958 & 0.037 & 0.123 & 0.919 & 0.200 & 0.227 & 0.058 & 0.038 & 0.004 & 4.95 \\
\hline Small hotel & 0.010 & 0.288 & 0.030 & 0.268 & 0.114 & 0.022 & 0.315 & 0.020 & 0.039 & 0.365 & 0.089 & 0.107 & 0.031 & 0.020 & 0.004 & 1.72 \\
\hline Warehouse & 0.349 & 2.590 & 0.580 & 2.966 & 2.298 & 0.154 & 2.446 & 0.068 & 0.435 & 3.580 & 0.688 & 0.466 & 0.049 & 0.043 & 0.002 & 16.72 \\
\hline $\begin{array}{l}\text { High-rise } \\
\text { apartment }\end{array}$ & 1.521 & 1.512 & 0.076 & 0.652 & 0.741 & 0.173 & 2.506 & 0.000 & 0.358 & 1.163 & 0.115 & 0.125 & 0.016 & 0.008 & 0.000 & 8.97 \\
\hline $\begin{array}{l}\text { Mid-rise } \\
\text { apartment }\end{array}$ & 0.257 & 1.094 & 0.093 & 0.825 & 0.862 & 0.260 & 1.694 & 0.022 & 0.371 & 1.122 & 0.318 & 0.313 & 0.056 & 0.032 & 0.000 & 7.32 \\
\hline Weights by Zone & 3.24 & 15.22 & 2.98 & 15.03 & 10.08 & 1.61 & 19.29 & 0.52 & 2.98 & 19.37 & 4.34 & 4.21 & 0.57 & 0.51 & 0.06 & 100.00 \\
\hline
\end{tabular}




\subsection{Inclusion of Addenda in the Quantitative Analysis}

PNNL examined each of the 110 addenda included in Standard 90.1-2013 and identified 57 of those as having a direct impact on energy efficiency and 53 that did not. Of those 57 addenda that had a direct impact on energy efficiency, 30 could be quantified using the simulation methodology for the preliminary quantitative analysis. The most common reason why an addendum with energy efficiency impacts was not included in the quantitative analysis was because the class of equipment or the particular requirements impacted by the addendum was not represented in the prototype buildings. Examples of this include addendum 90.1-2010bp - efficiency improvements for evaporative condensers with ammonia refrigerant, addendum 90.1-2010o - air leakage requirements for glazed sectional garage doors, and addendum 90.12010dq - sizing requirements for pipes greater than 24 inches in diameter. Other reasons for not including energy savings addenda were if they applied only to retrofit situations (e.g., addendum 90.12010bg - retrofit storm window efficiency) or if they enhanced quality assurance (e.g., addendum 90.12010dw - economizer high limit requirements for improved accuracy).

As discussed in Section 2.0, Standard 90.1 contains requirements for specific types of equipment, many of which are related to minimum federal efficiency standards. In some instances, a revised edition of Standard 90.1 will adopt a federal efficiency standard. Because that mandated equipment efficiency will be enforced as a manufacturing standard regardless of whether it is represented in Standard 90.1, the inclusion of the requirement in the ASHRAE standard is assumed to have no real energy impact due to the ASHRAE update. To address this issue, energy savings is not accounted for PNNL's quantitative analysis methodology for equipment efficiency improvements mandated by federal equipment efficiency standards. This avoids attributing energy savings in the quantitative analysis that would occur in new building construction regardless of the use of Standard 90.1, and it prevents an incorrect biasing of the quantitative analysis toward positive energy savings that would have occurred, and is accounted for, through federally mandated equipment efficiency improvements. Excluding energy savings for these addenda in the quantitative analysis is consistent with the approach used in previous DOE determinations. 


\subsection{Modeling of Specific Addenda}

This section details the modeling of the 30 addenda to Standard 90.1-2010 simulated for the quantitative analysis. Where individual addenda modify the same section of Standard 90.1, these addenda are discussed together.

\subsection{Addenda Characterization}

Figure 5.1 shows the number of addenda without energy impact, addenda with energy impact that are quantified, and addenda with energy impact that are not quantified. For the addenda with quantified savings, the figure shows the number of addenda associated with each chapter of Standard 90.1-2010. There are no addenda associated with Chapter 7, Service Water Heating, or with Chapter 10, Other Equipment that have quantified energy impact.

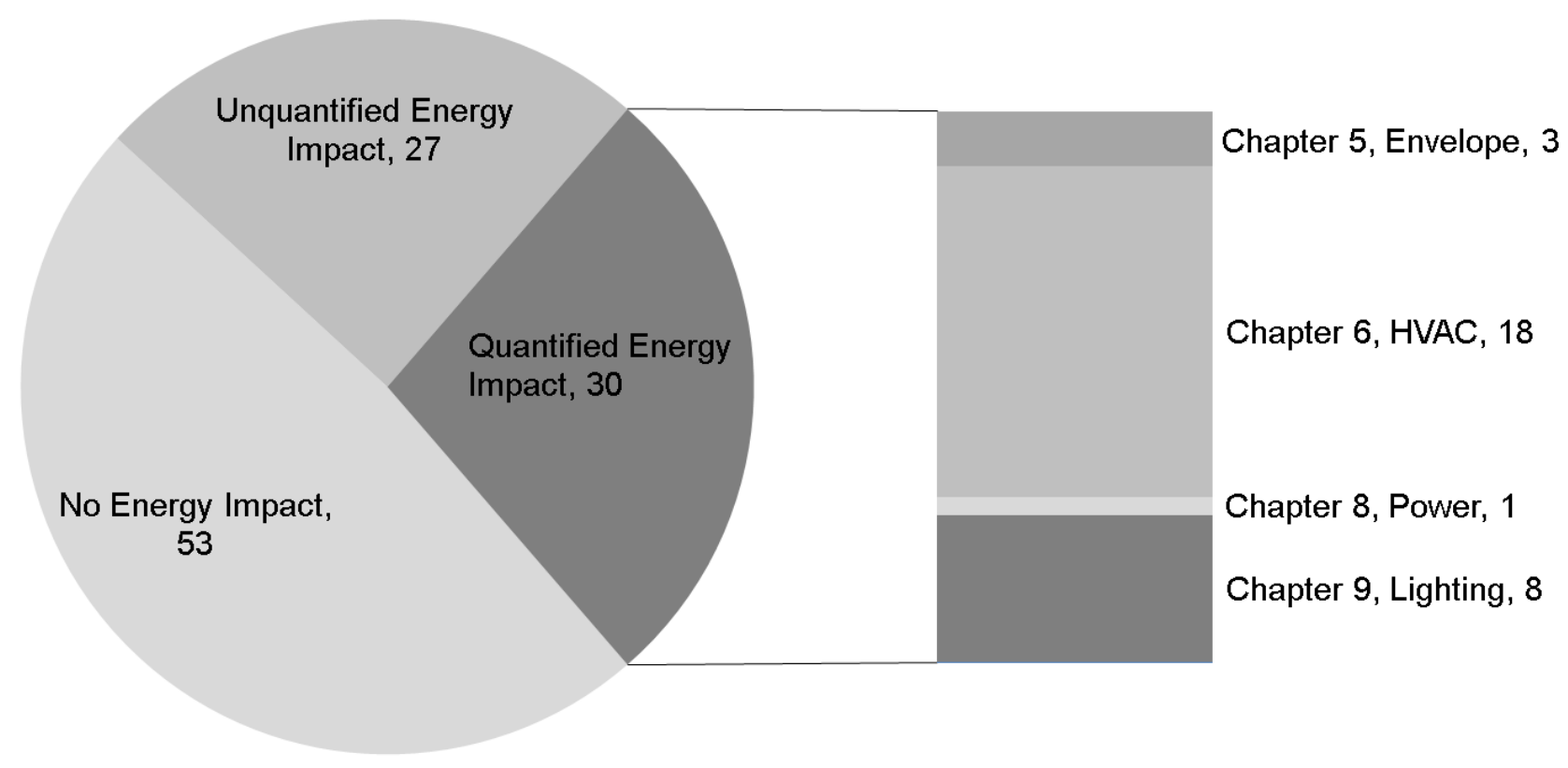

Figure 5.1. Addenda by Category and Quantity

Table 5.1 lists addenda that have an energy impact on the prototype buildings and have been captured in the analysis. Appendix B provides additional details about these addenda. Addenda listed in Appendix B are in a sorted hierarchy: (1) by the relevant Standard 90.1 chapter, and (2) sequential by alphabetical letter name of the addenda with two letter designations following single letter designations (e.g., " $\mathrm{t}$ " before “aa”). Addenda that affect more than one chapter in Standard 90.1, for example, those changing the building envelope and lighting controls for daylighting, are sorted into the Standard 90.1 chapter that is primarily responsible for the energy savings. Appendix B also identifies which prototype building is impacted by each of the quantified addenda. 
Table 5.1. Addenda with Quantified Energy Impacts

\begin{tabular}{clcl} 
Addendum & Description & Addendum & Description \\
\hline h & Water-to-air heat pump efficiency & bk & Increased PTAC efficiency \\
af & Heat rejection flow turndown & bs & Reduce threshold for DCV \\
aj & Small motor efficiency & bt & Reduces threshold for ERV \\
am & Boiler turndown requirements & bw & Orientation SHGC tradeoff \\
aq & Fan control and DX staging & by & Improved lighting controls \\
as & Humidification and pre-heat control & ca & Vestibule heating controls \\
au & Fan power credit adjustments & cb & Night setback and optimum start \\
ay & Enhances daylighting requirements & ch & Chiller efficiency \\
az & Cooling tower efficiency & co & Building area LPD update \\
ba & HVAC setback when doors are open & cr & Space-by-space lighting power update \\
bb & Comprehensive envelope upgrade & cy & Energy recovery for 24/7 occupancies \\
bc & Enhances daylighting requirements & di & Limits humidity controls \\
\hline bf & Automatic receptacle controls & Adj & $\begin{array}{l}\text { Aditional lighting power for } \\
\text { electrical/mechanical rooms }\end{array}$ \\
bh & Space-by-space lighting power & dl & Increases lighting power for guest rooms \\
bi & $\begin{array}{l}\text { Small heat pump and air conditioner } \\
\text { efficiency }\end{array}$ & dv & Chiller/boiler isolation \\
\hline & & &
\end{tabular}

\subsection{Addenda Implementation in Modeling}

The procedures for implementing the addenda into the Standard 90.1-2010 and 90.1-2013 prototype models include identifying the changes to the prototypes required by each addendum, developing model inputs to simulate those changes, applying those changes to the prototype models, running the simulations, and extracting and post-processing the results. This section explains the addenda and their impact on energy savings, the modeling strategies, and the development of the simulation inputs for EnergyPlus. Descriptions include identifying the change introduced by the addendum, the prototypes affected by the change, and a high-level summary of how the change was implemented in the prototype models. The terms "baseline" and "advanced" are used in some cases to describe the implementation of the addenda. The baseline is Standard 90.1-2010 and the advanced case is Standard 90.1-2013.

\subsubsection{Building Envelope}

\subsubsection{Addendum 90.1-2010bb: Opaque Envelope and Fenestration Performance}

Addendum 90.1-2010bb makes extensive changes to the opaque envelope and fenestration requirements in Chapter 5 of Standard 90.1-2010. It also introduces new requirements and makes editorial changes to the standard. The following list describes the changes from addendum 90.1-2010bb that have an impact on the energy consumption of buildings: 
1. Tables 5.5-1 through 5.5-8, the tables of prescriptive criteria for the building envelope, are updated. For opaque elements, minimum insulation levels are increased for most assemblies in most climate zones. For vertical fenestration, the U-factor requirements are more stringent for most framing types in most climate zones.

2. The fenestration framing types are changed from Standard 90.1-2010 to include non-metal framing, fixed metal framing, operable metal framing, and entrance door metal framing.

3. A minimum visible transmittance to solar heat gain coefficient ratio (VT/SHGC) is introduced in a new section, 5.5.4.6, to enhance daylighting while minimizing solar gain.

4. An exception is added to allow the skylight area to be increased to $6 \%$ where skylights are designed and utilized as part of a daylighting scheme. In Section 5.5.4.3, an exception is added to allow the skylight U-factor to be increased where skylights are designed and utilized as part of a daylighting scheme.

5. In Section 5.5.4.4, an exception is added that allows the SHGC criteria for vertical fenestration that faces north to be modified to account for the reduced solar heat gain on the north side of buildings in northern latitudes.

All the prototype buildings are impacted by the changes from addendum 90.1-2010bb. The change in opaque envelope and fenestration assembly requirements are captured in the prototype models, as is the new requirement for minimum VT/SHGC ratio. Other requirements having an energy impact are either optional (added for designed flexibility) or are not represented in the prototype buildings (for example, insulation requirements of heated slab-on-grade floors). A side-by-side comparison between Standard 90.1-2010 and addendum 90.1-2010bb opaque envelope and fenestration requirements is shown in Appendix $\mathrm{C}$ of this report.

To model the changes in wall and roof insulation requirements, U-factor requirements from addendum 90.1-2010bb are used to calculate the R-value of the insulation layer in the construction assembly, which is built using the assembly descriptions from Appendix A of Standard 90.1-2013. For the slab-on-grade assembly, the R-value insulation requirements are modeled directly using the slab preprocessor in EnergyPlus.

The fenestration requirements are determined by weighting the U-factor of different framing types for each prototype building model. The weighted U-factor together with the SHGC (SHGC requirements are the same for all framing types) and VT from prescriptive tables is used to find a matching assembly in the EnergyPlus fenestration library that complies with the requirements. The framing type weights are taken from the Analysis of 90.1-2010 (Thornton et al. 2011). The fixed metal framing and operable metal framing types introduced by addendum 90.1-2010bb use the same weights as those used in 90.1-2010 for curtain wall/storefront metal framing and all other metal framing, respectively.

\subsubsection{Addendum 90.1-2010bw: Fenestration Orientation}

Addendum 90.1-2010bw modifies the fenestration orientation requirements in Section 5.5.4.5 of Standard 90.1-2010. The new requirements allow compliance through one of two methods:

1. by making each of the west- and east-oriented fenestration area less than or equal to a quarter of the total building fenestration area, or, 
2. by making each of the product of west- and east-oriented fenestration area and SHGC less than or equal to a quarter of the product of the total building fenestration area and the SHGC criteria established in Tables 5.5-1 through 5.5-8.

Buildings in climate zone 8 are exempt from these requirements. The addendum introduces a new exception, exception (e), for buildings where, if the window-to-wall ratio of the east or west facade is less than $20 \%$, the requirement is considered to be met if the SHGC is reduced by $10 \%$ over the prescribed value for that facade.

To model the Standard 90.1-2010 fenestration orientation requirements, prototype models were rotated by 90 degrees (Small Hotel and Hospital) because SHGC trade-off was not allowed. Addendum 90.1-2010bw allows trading-off the SHGC with the fenestration area, and this path is most likely to be used by designers for compliance. This is the path chosen for modeling the requirements. Rotated prototype models that were modeled to meet 90.1-2010 requirements are used to check whether the new requirements are met (the Standard 90.1-2010 models are the starting point for the Standard 90.1-2013 models). For those prototype buildings that do not meet the simpler area requirements of addendum 90.12010bw, the SHGC trade-off equation is used to calculate a new SHGC for the west- or east-oriented fenestration that would meet the requirements.

There are four prototypes that do not meet the fenestration area requirement: Hospital, Quick-service Restaurant, Full-service Restaurant, and Warehouse. For these prototypes, the SHGCs required for compliance are calculated separately for east- and west-oriented fenestration. The calculated SHGCs are applied only to the west- and east-oriented fenestration of the impacted prototypes. The office space in the Warehouse prototype causes non-compliance, but it is ignored because the fenestration area is very small. For the Hospital prototype, the east-oriented fenestration area is less than $20 \%$ of the gross wall area, allowing exception (e) in the addendum to be used. Table 5.2 shows the new SHGC values calculated for the east- and west-oriented fenestration by climate zone (CZ).

Table 5.2. New SHGC Values Meeting Addendum 90.1-2010bw Fenestration Orientation Requirements

\begin{tabular}{lccccccccc}
\hline & \multicolumn{3}{c}{ Hospital } & \multicolumn{3}{c}{ Quick-service Restaurant } & \multicolumn{3}{c}{ Full-service Restaurant } \\
\cline { 2 - 9 } \multicolumn{1}{c}{ SHGC } & CZ 1-3 & CZ 4-6 & CZ 7 & CZ 1-3 & CZ 4-6 & CZ 7 & CZ 1-3 & CZ 4-6 & CZ 7 \\
\hline $\begin{array}{l}\text { 90.1-2013 Prescriptive } \\
\text { SHGC }\end{array}$ & 0.25 & 0.4 & 0.45 & 0.25 & 0.4 & 0.45 & 0.25 & 0.4 & 0.45 \\
Calculated East SHGC & 0.23 & 0.36 & 0.41 & 0.25 & 0.40 & 0.45 & 0.21 & 0.34 & 0.38 \\
Calculated West SHGC & - & - & - & 0.25 & 0.40 & 0.45 & 0.21 & 0.34 & 0.38 \\
\hline
\end{tabular}

\subsubsection{Addendum 90.1-2010ca: Vestibule Heating}

Addendum 90.1-2010ca adds two requirements for heated vestibules to Section 6.4.3.9 in Standard 90.1-2013. Section 6.4.3.9 is a new section resulting from the renumbering of sections in Section 6.4 of Standard 90.1-2013. The new vestibule heating requirements are discussed here because vestibules are an integral part of the envelope requirements in Chapter 5 of Standard 90.1. Addendum 90.1-2010ca requires heated vestibules to have controls to limit the heating setpoint to a maximum of $60^{\circ} \mathrm{F}$ and the vestibule heating system is required to include automatic controls configured to shut off the heating system when the outdoor air temperature is above $45^{\circ} \mathrm{F}$. Vestibules without heating systems or the ones heated by transfer air are exempted from meeting these requirements. 
Addendum 90.1-2010ca only impacts the Standalone Retail prototype building, which has a designated thermal zone serving the purpose of a vestibule, heated using a unit heater. The unit heater is fitted with a gas heating coil and follows the same thermostat setpoint and schedule as the rest of the building.

The requirements of addendum 90.1-2010ca are implemented using a two-step approach: (1) a new thermostat schedule is created for the vestibule zone, such that the heating setpoint is limited to a maximum of $60^{\circ} \mathrm{F}$, and (2) an energy management system (EMS) routine is created to shut off the unit heater heating coil and fan when the outdoor air temperature is above $45^{\circ} \mathrm{F}$. The EMS in EnergyPlus is a user-accessible programming functionality that can adjust parameters during program simulation. Figure 5.2 shows the original and the new thermostat heating setpoint schedule for the vestibule zone.

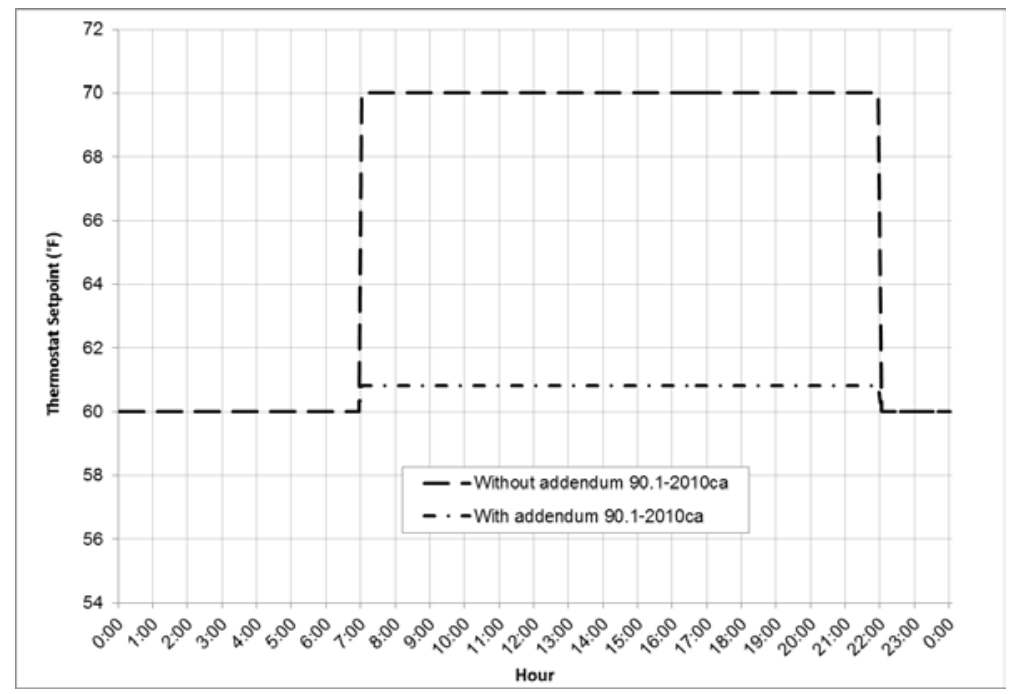

Figure 5.2. Heating Setpoints for Vestibule Zone in the Standalone Retail Prototype Building

\subsubsection{Heating, Ventilating, and Air-Conditioning}

\subsubsection{Addendum 90.1-2010g: Reach-in Refrigerators and Freezer Equipment}

DOE has defined maximum energy consumption requirements for selected commercial refrigerators and freezers that went into effect on 1/1/2010. Additional requirements for commercial refrigeration equipment have also been defined and approved per 10 CFR part 431 and went into effect on 1/1/2012. Addendum 90.1-2010g adds these requirements through two new tables in Chapter 6 (Tables 6.8.1-12 and 6.8.1-13) of Standard 90.1. Among the equipment listed in the two tables, commercial reach-in refrigerators with solid doors and commercial reach-in freezers with solid doors are modeled in prototype buildings with commercial kitchens: Quick-service Restaurant, Full-service Restaurant, Hospital, Large Hotel, Primary School, and Secondary School. Navigant (2009) provided a summary of typical sizes and numbers of the applicable equipment in the prototype buildings. Table 5.3 shows the typical sizes and numbers of commercial freezers and refrigerators in the prototype buildings. 
Table 5.3. Typical number of Commercial Refrigerators and Freezers in Prototype Models

\begin{tabular}{cccc}
\hline Prototype & Building Type & $\begin{array}{c}\text { Number of commercial } \\
\text { freezers with solid doors } \\
\left.\text { (typical volume } \mathrm{V}=24 \mathrm{ft}^{3}\right)\end{array}$ & $\begin{array}{c}\text { Number of commercial } \\
\text { refrigerators with solid } \\
\text { doors (typical volume } \\
\mathrm{V=48} \mathrm{ft}^{3} \text { ) }\end{array}$ \\
\hline Quick-service Restaurant & Food Service & 1 & 2 \\
\hline Full-service Restaurant & Food Service & 1 & 2 \\
Hospital & Health Care & 2 & 3 \\
Large Hotel & Lodging & 1 & 1 \\
\hline Primary School & Education & 2 & 2 \\
\hline Secondary School & Education & 2 & 2 \\
\hline
\end{tabular}

Table 6.8.1-12 in addendum 90.1-2010g defines the energy use limits in $\mathrm{kWh} /$ day as a function of the volume $(\mathrm{V})$ in $\mathrm{ft}^{3}$. These limits are converted to input power and are modeled as a plug load with a constant operation schedule in EnergyPlus. To develop baseline inputs for the prototype models, the California Title 20 requirement (CEC 2008), effective 3/1/2003, is used to calculate the energy use limits without addendum 90.1-2010g. Table 5.4 shows the energy use limits used to calculate the input power of commercial refrigerators and freezers for the baseline and advanced models. For the Standard 90.12013 determination analysis, both the 90.1-2010 and 90.1-2013 models include the impact of addendum 90.1-2010g because it is a federally mandated requirement and there is no credit to Standard 90.1-2013 from the requirement.

Table 5.4. Summary of Energy Use Limits for Commercial Refrigerators and Freezers in Prototypes

\begin{tabular}{lcc}
\hline \multicolumn{1}{c}{ Equipment } & $\begin{array}{c}\text { Energy Use Limits Before } \\
\text { Addendum 90.1-2010g } \\
(\mathrm{kWh} / \text { day })\end{array}$ & $\begin{array}{c}\text { Energy Use Limits After } \\
\text { Addendum 90.1-2010g } \\
(\mathrm{kWh} / \text { day })\end{array}$ \\
\hline Reach-in refrigerators with solid doors & $0.125 \mathrm{~V}+4.22$ & $0.10 \mathrm{~V}+2.04$ \\
Reach-in freezers with solid doors & $0.398 \mathrm{~V}+2.83$ & $0.40 \mathrm{~V}+1.38$ \\
\hline
\end{tabular}

\subsubsection{Addendum 90.1-2010h: Water to Air Heat Pump Efficiency}

Addendum 90.1-2010h improves the minimum energy efficiency standards for water-to-air heat pumps (water loop, ground water, and ground loop) listed in Table 6.8.1B of Standard 90.1-2010 (now Table 6.8.1-2 of Standard 90.1-2013).

Table 5.5 shows the minimum energy efficiency ratio (EER) and coefficient of performance (COP) requirements for water-to-air heat pump as required by Standard 90.1-2010 (before addendum 90.12010h) and by addendum 90.1-2010h. 
Table 5.5. Impacted Equipment and Efficiency Changes Required by Addendum 90.1-2010h

\begin{tabular}{|c|c|c|c|c|}
\hline \multirow[b]{2}{*}{ Equipment Type } & \multirow[b]{2}{*}{ Size Category } & \multirow[b]{2}{*}{ Rating Condition } & \multicolumn{2}{|c|}{ Minimum Efficiency } \\
\hline & & & $90.1-2010$ & $\begin{array}{c}\text { Addendum 90.- } \\
\text { 2010h }\end{array}$ \\
\hline \multirow{3}{*}{$\begin{array}{l}\text { Water to Air: Water } \\
\text { Loop (cooling } \\
\text { mode) }\end{array}$} & $<17,000 \mathrm{Btu} / \mathrm{h}$ & $86^{\circ} \mathrm{F}$ entering water & $11.2 \mathrm{EER}$ & $12.2 \mathrm{EER}$ \\
\hline & $\begin{array}{c}\geq 17,000 \mathrm{Btu} / \mathrm{h} \text { and } \\
<65,000 \mathrm{Btu} / \mathrm{h}\end{array}$ & $86^{\circ} \mathrm{F}$ entering water & 12.0 EER & 13.0 EER \\
\hline & $\begin{array}{c}\geq 65,000 \mathrm{Btu} / \mathrm{h} \text { and } \\
<135,000 \mathrm{Btu} / \mathrm{h}\end{array}$ & $86^{\circ} \mathrm{F}$ entering water & 12.0 EER & 13.0 EER \\
\hline $\begin{array}{l}\text { Water to Air: } \\
\text { Ground Water } \\
\text { (cooling mode) }\end{array}$ & $<135,000 \mathrm{Btu} / \mathrm{h}$ & $59^{\circ} \mathrm{F}$ entering water & 16.2 EER & 18.0 EER \\
\hline $\begin{array}{l}\text { Brine to Air: } \\
\text { Ground Loop } \\
\text { (cooling mode) }\end{array}$ & $<135,000 \mathrm{Btu} / \mathrm{h}$ & $77^{\circ} \mathrm{F}$ entering fluid & 13.4 EER & 14.1 EER \\
\hline $\begin{array}{l}\text { Water to Air: Water } \\
\text { Loop (heating } \\
\text { mode) }\end{array}$ & $\begin{array}{c}<135,000 \mathrm{Btu} / \mathrm{h} \\
\text { (cooling capacity) }\end{array}$ & $68^{\circ} \mathrm{F}$ entering water & $4.2 \mathrm{COP}$ & $4.3 \mathrm{COP}$ \\
\hline $\begin{array}{l}\text { Water to Air: } \\
\text { Ground Water } \\
\text { (heating mode) }\end{array}$ & $\begin{array}{c}<135,000 \mathrm{Btu} / \mathrm{h} \\
\text { (cooling capacity) }\end{array}$ & $50^{\circ} \mathrm{F}$ entering water & $3.6 \mathrm{COP}$ & 3.7 COP \\
\hline $\begin{array}{l}\text { Brine to Air: } \\
\text { Ground Loop } \\
\text { (heating mode) }\end{array}$ & $\begin{array}{c}<135,000 \mathrm{Btu} / \mathrm{h} \\
\text { (cooling capacity) }\end{array}$ & $32^{\circ} \mathrm{F}$ entering fluid & $3.1 \mathrm{COP}$ & $3.2 \mathrm{COP}$ \\
\hline
\end{tabular}

Of the 16 prototype buildings, only the High-rise Apartment Building uses water-loop heat pumps. The other two water-to-air heat pumps (ground water and ground loop) are not used in any of the 16 prototype buildings. Therefore, High-rise Apartment Building is the only building type affected by addendum 90.1-2010h.

For each building model in each climate zone simulated, the heat pumps are sized using the design day sizing analysis, and the efficiency of the heat pump is determined for the model based on the design capacity and the required efficiency from each version of Standard 90.1. The conversion of efficiency from EER and COP to EnergyPlus inputs is documented in the Analysis of 90.1-2010 (Thornton et al. 2011).

\subsubsection{Addendum 90.1-2010af: Heat Rejection Equipment}

Addendum 90.1-2010af includes two major changes to Standard 90.1-2010: fan control for multi-cell heat rejection equipment (Section 6.5.5.2) and open-circuit cooling tower flow turndown (Section 6.5.5.4). The addendum requires that the maximum number of fans operate in a multi-cell heat rejection equipment installation to minimize energy. It is more energy efficient to operate all fans in tandem at the same (lower) fan speed than to have an on/off or sequenced fan operation (operating a select number of cells at full speed to meet load). Using more cells also increases heat transfer area and more heat can be rejected with less airflow and fan speed.

The fan control requirement applies to air cooled chillers that have fans 7.5 horsepower (hp) or larger. A review of the largest chiller required for either the large hotel or the secondary school shows that a typical fan is in the $3 \mathrm{hp}$ to $5 \mathrm{hp}$ range, so would not trigger the fan control requirement. 
The tower flow turndown requirement states that open-circuit cooling towers used on water-cooled chiller systems that are configured with multiple or variable speed condenser water pumps shall be designed so that all open circuit cooling tower cells can be run in parallel with the larger of either the flow that is produced by the smallest pump at its minimum expected flow rate, or $50 \%$ of the design flow for each cell.

The Large Office and Hospital are the two prototype buildings using open-circuit cooling towers. For these two prototype buildings, the model has two variable-speed cooling towers. Each tower has one dedicated condenser water pump and two cells. Because the two cooling towers are equally sized, the two condenser water pumps have the same design flow rate. Before implementing addendum 90.12010af, the number of operating cooling towers and condenser water pumps corresponded to the number of operating chillers. When one chiller was operating, one cooling tower was operating and the corresponding condenser water pump was also operating. When both chillers were running, both cooling towers and both condenser water pumps were running.

Addendum 90.1-2010af requires that the maximum number of fans operate to minimize fan energy. This means that when one chiller is running, all four cell fans in the two cooling towers shall be operating unless the fan in one cooling tower already runs at its minimum speed. Running two towers implies that the condenser water flow will be reduced by $50 \%$ for each cell in comparison with running one tower.

Major elements of the strategy for modeling addendum 90.1-2010af include the following:

1. Change the cell control strategy for variable speed cooling towers in EnergyPlus from "minimum cells" to "maximum cells."

2. For each time step, find the number of operating chillers.

3. If one chiller is running and the current airflow ratio is greater than the minimum, run the two towers in parallel. Use the EnergyPlus EMS to halve the airflow ratio, which is then used to calculate the fan power according to the cubic power law. The EMS control is necessary because EnergyPlus native control algorithms cannot run both towers in parallel while delivering the condenser water flow just for one chiller if there are two chillers in the plant.

4. If two chillers are running or the current airflow is at the minimum when one chiller is running, the EMS routine will not override the tower fan curve input and output.

\subsubsection{Addendum 90.1-2010aj: Fractional HP Motors}

Addendum 90.1-2010aj adds a new Section 6.5.3.5 to Standard 90.1-2010 and requires motors from 1/12 horsepower (hp) to under $1 \mathrm{hp}$ to be electronically commutated (EC) motors or have a minimum efficiency of 70\%. The intention is to replace standard permanent-split capacitor (PSC) motors having efficiencies in the range of $15 \%$ to $65 \%$ with more-efficient EC motors. The intended applications are toilet exhaust fans, small kitchen exhaust fans, series fan-powered variable air volume (VAV) boxes, and fan-coil units. The following motors are exempted under addendum 90.1-2010aj: motors in airstream where only heating is provided, motors in packaged equipment, poly-phase small motors, and capacitorstart capacitor-run and capacitor-start induction-run motors that are covered by Table 10.8-4 and Table 10.8-5 in Standard 90.1-2013. 
In the prototype building models, this addendum will apply to fan-coil units, exhaust fans, kitchen exhaust fans, and elevator fans. Of the 16 prototype buildings, only the Small Office, Standalone Retail, and Strip Mall prototypes have no impact from addendum 90.1-2010aj. Table 5.6 provides details on the prototype buildings and fans to which this addendum applies.

Table 5.6. Prototype buildings Affected by Addendum 90.1-2010aj

\begin{tabular}{lcccc}
\hline Prototype Building & Fan-Coil Unit & Exhaust Fan & Kitchen Exhaust fan & Elevator Fan \\
\hline Highrise Apartment & & & & Yes \\
Midrise Apartment & & & Yes & Yes \\
Hospital & Yes & Yes & Yes & Yes \\
Large Hotel & & & Yes \\
Small Hotel & & & Yes \\
Large Office & & & Yes \\
Medium Office & Yes & Yes & Yes \\
Outpatient Healthcare & & Yes & Yes & \\
Quick Service Restaurant & & Yes & Yes & \\
Full Service Restaurant & & Yes & & Yes \\
Primary School & Yes & & \\
Secondary School & & & & \\
\hline
\end{tabular}

To determine the motors whose efficiency must be changed, a set of criteria is established based on motor size. From a review of catalogs, motors in the smallest fans are selected from standard fractional horsepower motor sizes even if the required brake horsepower (bhp) is much lower. Therefore, maximum bhp is set at $90 \%$ of $3 / 4 \mathrm{hp}$ or $560 \mathrm{~W}$ (above $90 \%$ of 3/4 hp, a $1 \mathrm{hp}$ or larger motor would be used) and minimum bhp is set at $25 \%$ of $1 / 12 \mathrm{hp}$, or $14 \mathrm{~W}$. Motors between the minimum and maximum bhp are considered to be applicable to the requirements of addendum 90.1-2010aj.

To implement the requirements of addendum 90.1-2010aj, motor efficiency is changed. Before applying this change, fan properties in different prototypes were reviewed and unified for consistent application across prototypes. This baseline change is documented in Enhancements to ASHRAE Standard 90.1 Prototype Building Models (PNNL 2014). As part of this change, the fan mechanical efficiency is set to 55\%, and the baseline or PSC motor efficiency is set to $29 \%$. To capture the impact of addendum 90.1-2010aj, the advanced or EC motor efficiency is set to $70 \%$.

For Standard 90.1-2010 models, the baseline motor efficiency is used, whereas for Standard 90.12013 models, the advanced motor efficiency is used. Table 5.7 summarizes the baseline and advanced fan properties for the fan systems affected by addendum 90.1-2010aj. 
Table 5.7. Baseline and Advanced Fan Assumptions for Different Fan Systems

\begin{tabular}{|c|c|c|c|c|c|c|c|}
\hline \multirow{2}{*}{$\begin{array}{c}\text { Type of } \\
\text { Fan System }\end{array}$} & $\begin{array}{c}\text { Static } \\
\text { Pressure, } \\
\text { in. w.c. }\end{array}$ & $\begin{array}{l}\text { Fan Mech. } \\
\text { Efficiency }\end{array}$ & $\begin{array}{c}\text { Motor } \\
\text { Efficiency }\end{array}$ & $\begin{array}{l}\text { Total Fan } \\
\text { Efficiency }\end{array}$ & $\begin{array}{c}\text { Motor } \\
\text { Efficiency }\end{array}$ & $\begin{array}{l}\text { Total Fan } \\
\text { Efficiency }\end{array}$ & \multirow{2}{*}{$\begin{array}{c}\text { Modeling } \\
\text { Approach in } \\
\text { EnergyPlus }\end{array}$} \\
\hline & All & All & \multicolumn{2}{|c|}{ Baseline } & \multicolumn{2}{|c|}{ Advanced } & \\
\hline $\begin{array}{l}\text { Fan-Coil } \\
\text { Units }\end{array}$ & 1.088 & $55 \%$ & $29 \%$ & $16 \%$ & $70 \%$ & $39 \%$ & $\begin{array}{l}\text { Modeled as fan } \\
\text { system }\end{array}$ \\
\hline $\begin{array}{l}\text { Exhaust } \\
\text { Fans }\end{array}$ & 0.500 & $55 \%$ & $29 \%$ & $16 \%$ & $70 \%$ & $39 \%$ & $\begin{array}{l}\text { Modeled as fan } \\
\text { system }\end{array}$ \\
\hline $\begin{array}{l}\text { Kitchen } \\
\text { Fans }\end{array}$ & 0.500 & $55 \%$ & $29 \%$ & $16 \%$ & $70 \%$ & $39 \%$ & $\begin{array}{l}\text { Modeled as } \\
\text { plug load }\end{array}$ \\
\hline $\begin{array}{l}\text { Elevator } \\
\text { Exhaust }\end{array}$ & 0.4480 & $55 \%$ & $29 \%$ & $16 \%$ & $70 \%$ & $39 \%$ & $\begin{array}{l}\text { Modeled as } \\
\text { plug load }\end{array}$ \\
\hline
\end{tabular}

\subsubsection{Addendum 90.1-2010am: Boiler Turndown}

Addendum 90.1-2010am adds a new Section, 6.5.4.6 to Standard 90.1-2013, and requires that boiler systems with design input of at least 1,000,000 Btu/h comply with a turndown ratio as specified in Table 6.5.4.6. Table 5.8 shows the boiler turndown requirements of addendum 90.1-2010am.

Table 5.8. Boiler Turndown Required by Addendum 90.1-2010am

\begin{tabular}{lc}
\hline \multicolumn{1}{c}{$\begin{array}{c}\text { Boiler System Design Input } \\
\text { (Btu/h) }\end{array}$} & $\begin{array}{c}\text { Minimum } \\
\text { Turndown Ratio }\end{array}$ \\
\hline$\geq 1,000,000$ and less than or equal to $5,000,000$ & 3 to 1 \\
$>5,000,000$ and less than or equal to $10,000,000$ & 4 to 1 \\
$>10,000,000$ & 5 to 1 \\
\hline
\end{tabular}

The following prototype buildings use boilers that may be affected by the turndown requirements: Large Office, Hospital, Primary School, Secondary School, Large Hotel, High-rise Apartment, and Outpatient Healthcare.

The baseline control type for the prototype models is assumed to be single-stage capacity control (PNNL 2014). Compared with the single-stage capacity control, modulating boiler capacity as required by addendum 90.1-2010am will improve the boiler performance at part-load conditions. Part-load curves are developed for single-stage capacity control and modulating capacity control (PNNL 2014).

The following steps describe the logic in implementing the requirements of addendum 90.1-2010am into the baseline and advanced models:

1. For the baseline models, the following part load efficiency curve is used:

$$
\text { Single Stage Curve }=0.907+0.320 * P L R-0.420 * P L R^{2}+0.193 * P L R^{3}
$$

2. For the advanced models, boiler systems with input capacity $<1,000 \mathrm{MBH}$ use the single stage curve, whereas boiler systems with input capacity >1,000 MBH, use the following curve:

$$
\text { ModCurve }=0.975+0.305 * \mathrm{PLR}-0.527 * \mathrm{PLR}^{2}+0.249 * \mathrm{PLR}^{3}
$$


3. When the part load ratio (PLR) is below the minimum turndown ratio, the curve output will be calculated by

$$
\text { Curve }_{\mathrm{PLR}}=\frac{\mathrm{PLR}}{\mathrm{PLR}+2 \%} * \frac{\mathrm{Ec} \min }{\mathrm{Et}}
$$

4. Step 3 applies to both baseline and advanced models.

\subsubsection{Addendum 90.1-2010aq: Staged Cooling and Economizer Integration}

Addendum 90.1-2010aq introduced several new requirements related to direct expansion (DX) cooling capacity control, air economizer integration and fan airflow control to Chapter 6, and modified the requirements in both the mandatory requirements (Section 6.4) and the prescriptive requirements (Section 6.5) of Standard 90.1-2010. The requirements of addendum 90.1-2010aq (effective 1/1/2016) can be summarized as follows:

1. For DX units $\geq 65,000 \mathrm{Btu} / \mathrm{h}$ that control cooling capacity directly based on space temperature (usually serving a single zone), a minimum of two stages of mechanical cooling capacity is required. DX units $\geq 65,000$ and $<240,000 \mathrm{Btu} / \mathrm{h}$ that modulate airflow shall have three stages of cooling with minimum compressor displacement $\leq 35 \%$ while DX units $\geq 240,000 \mathrm{Btu} / \mathrm{h}$ that modulate airflow shall have four stages of cooling with minimum compressor displacement $\leq 25 \%$

2. For DX units that control cooling capacity directly based on space temperature (usually serving a single zone), a minimum of two stages of fan control is required. Low or minimum speed is not allowed to exceed $66 \%$ of full speed.

3. DX cooling capacity control is required to be interlocked with air economizer controls such that $100 \%$ outdoor air can be supplied when mechanical cooling is on and outdoor airflow is only reduced after the discharge air temperature has dropped below $45^{\circ} \mathrm{F}$.

A new method of simulating economizer operation is introduced to improve the modeling of partial economizer operation and to capture the difference in partial economizer operation between single-stage cooling and two-stage cooling as required by addendum 90.1-2010aq. This new method is described in Enhancements to ASHRAE Standard 90.1 Prototype Building Models (PNNL 2014).

\section{Modeling Cooling Capacity Control}

The following prototype building models use packaged single-zone DX cooling units: Standalone Retail, Strip Mall, Quick-service Restaurant, Full-service Restaurant, Primary School, Secondary School, Small Hotel, and Warehouse. Except for the single-zone systems in Small Hotel and Warehouse buildings, the cooling capacity of DX units found in the prototypes is larger than 65,000 Btu/h in most climate zones. DX units larger than 65,000 Btu/h have been installed with two-stage compressors for a long period in the market. Therefore, it is assumed that all packaged single-zone DX cooling units in Standard 90.1-2010 models and 90.1-2013 models, except those Small Hotel and Warehouse, have twostage compressors. DX cooling in these prototypes is modeled using the two-stage cooling object (Coil:Cooling:DX:TwoSpeed) in EnergyPlus. For Standard 90.1-2010 and 90.1-2013 models, the lowstage capacity is assigned to be half the high-stage capacity. 
Improved economizer integration is a source of savings from staged cooling. When the cooling capacity thresholds for requiring staged cooling are exceeded in Standard 90.1-2010 and 90.1-2013 models, economizer operation is modified to represent increased economizer effectiveness. The fraction of time spent by the system in each mode-full economizer, partial economizer, and full mechanical cooling - is used to calculate an average economizer effectiveness for a given time step. Economizer effectiveness is adjusted by changing the maximum outside air schedule that controls the amount of outside air available at a time step. Economizer effectiveness calculations are described in greater detail in Enhancements to ASHRAE Standard 90.1 Prototype Building Models (PNNL 2014).

Packaged DX cooling units for multiple zones are used in the following prototype models: Medium Office, Primary School, and Outpatient Healthcare. These units are currently modeled as two-stage DX cooling for discharge air temperature control. Based on addendum 90.1-2010aq, the number of cooling stages is required to be increased to three for those units with cooling capacity in between 65,000 and $240,000 \mathrm{Btu} / \mathrm{h}$ and increased to four for those units with cooling capacity more than 240,000 Btu/h. In EnergyPlus, the multi-speed DX cooling object (Coil:Cooling:DX:Multispeed) cannot be used to model unitary air conditioners. In addition, the cooling capacity cannot be overridden with EMS control. Although it might be possible to consider the impact via the part-load performance curve, the challenge is the lack of data to support the curve development. Therefore, the impact of reduced compressor cycling for packaged VAV units is not captured.

\section{Modeling Fan Airflow Control}

For packaged DX cooling units serving single zones, the threshold of cooling capacity is reduced from $110,000 \mathrm{Btu} / \mathrm{h}$ to $65,000 \mathrm{Btu} / \mathrm{h}$ for fan speed control by addendum $90.1-2010 \mathrm{aq}$. Previously, while modeling the requirements for single-zone VAV in Standard 90.1-2010, a workaround was used to emulate single-zone VAV control. Because this workaround could not capture the required fan speed control very well, the EMS is used to capture the impact of fan speed control. Using the EMS, the percentage of time for different operation modes (ventilation, economizing, first-stage DX cooling, and second-stage DX cooling) is calculated.

In each time step, the compressor speed ratio is used to determine the percentage of time when the compressor runs at its rated speed. The DX coil runtime fraction is then used to determine the percentage of time in ventilation mode and economizing mode. The logic works as follows:

1. If the compressor speed ratio is greater than 0 , the percentage of first-stage DX cooling is equal to 1 minus compressor speed ratio.

2. If the compressor speed ratio is equal to 0 , the DX cooling coil runtime fraction is the percentage of time for first-stage DX cooling.

3. Next, if the DX coil runtime fraction is greater than 0 , the percentage of time for ventilation mode is equal to 1 minus DX coil runtime fraction.

4. If the DX coil runtime fraction is equal to 0 , the unit is in either ventilation mode or economizing mode for the whole time step. 
5. To differentiate between ventilation and economizing mode, the current outdoor airflow is compared to the minimum. If it is higher than minimum, the unit is in the economizing mode; otherwise, it is in the ventilation mode.

Addendum 90.1-2010aq also requires that units with air economizer shall have a minimum of two speeds of fan control during economizer operation. The fan speed control in economizing mode intends to avoid using excess fan energy when outside air is cold enough to provide cooling at partial air flow. In the model, the desired discharge air temperature is calculated to meet the space load assuming the fan runs at its low speed. If the outdoor air temperature is lower than the desired discharge air temperature, the fan is assumed to run at its low speed; otherwise, the fan runs at its high speed.

There are no changes on airflow control from this addendum for packaged VAV systems. Therefore, prototype buildings with packaged VAV systems (Medium Office, Primary School, and Outpatient Healthcare) do not have model changes on supply fan airflow control.

\section{Implementation of Addendum 90.1-2010aq in Prototype building Models}

As described earlier, the EMS is used to implement improved economizer effectiveness with twostage cooling and fan-speed control. The applicable HVAC systems in each model are checked to determine the cooling capacity and whether the capacity thresholds are exceeded. Depending on the capacity, each system is assigned single-stage or two-stage operation. The economizer effectiveness and fan speed are calculated by the EMS routines for each time-step.

\subsubsection{Addendum 90.1-2010ar: Refrigeration Equipment}

Addendum 90.1-2010ar expands the scope of Standard 90.1 to cover requirements for refrigeration equipment including walk-in coolers and freezers and refrigeration systems. The new requirements for walk-in coolers and freezers have been defined and legislated as the national manufacturing standard and described in 10 Code of Federal Regulations (CFR) 431.306. They are added to Standard 90.1 in a new Section, 6.4.5. The requirements are for walk-ins cover doors, insulation, evaporator fan motor, lighting, anti-sweat heater, condenser fan motor, and their controls. The requirements for refrigeration systems include fan-powered condenser controls and a minimum saturated condensing temperature setpoint.

Six prototype buildings with commercial kitchens are affected by addendum 90.1-2010ar: Quickservice Restaurant, Full Service Restaurant, Hospital, Large Hotel, Primary School, and Secondary School. Because the walk-in coolers and freezers in these prototype buildings are assumed to be packaged and without remote compressors and condensers, the refrigeration system requirements of addendum 90.1-2010ar do not apply to these prototype buildings.

Navigant (2009) developed characteristics of baseline walk-in coolers and freezers while evaluating potential energy savings from the equipment. It is found that the baseline characteristics either meet or exceed most requirements in addendum 90.1-2010ar except the evaporator fan motor and the lighting requirements. To capture these new requirements, the evaporator fan motors in baseline models are assumed to be shaded pole motors ( $1 / 20 \mathrm{hp}$ ) for walk-in coolers and shaded pole motors (1/40 hp) for walk-in freezers with a motor efficiency of $20 \%$. The motors are changed to EC motors in the advanced models with a motor efficiency of $70 \%$. The average efficiencies of shaded pole and EC motors are 
determined by surveying typical efficiencies listed in manufacturer catalogs. The differences in efficiency are reflected in the fan power inputs in EnergyPlus.

Light sources with a minimum efficacy of 40 lumens per Watt are assumed to be in the baseline walkins, although this minimum efficacy is required by addendum 90.1-2010ar. The impact of the lighting control requirement is modeled as a $10 \%$ reduction in the hourly lighting schedule in the advanced models. This simulates the energy saving benefits from an occupancy sensor based lighting control.

Both the EC fan motor efficiency and lighting schedule reduction are applied to the Standard 90.12010 models because addendum 90.1-2010ar introduces federally mandated requirements that do not provide credit to Standard 90.1-2013.

\subsubsection{Addendum 90.1-2010as: Humidification System Requirements}

Addendum 90.1-2010as makes changes to Sections 6.5.2.4.1, 6.5.2.4.2, 6.5.2.4.3 and 6.5.2.5 of Standard 90.1-2010. The requirements in Sections 6.5.2.4.1 and 6.5.2.4.2 already exist in 90.1-2010; they are marked as changes because their location in Section 6.5 is changed. Sections 6.5.2.4.3 and 6.5.2.5 are new requirements. Section 6.5.2.4.3 requires a minimum of R-0.5 insulation on humidifier steam dispersion assemblies. Section 6.5.2.5 requires preheat coils to stop operation during cooling or economizing. Modeling approaches to the two sections are discussed below.

\section{Impact of Insulation on Humidifier Steam Dispersion Assembly}

The insulation requirement on humidifier steam dispersion assembly affects those air systems with humidifiers. These systems occur in the Hospital (VAV_ER, VAV_OR, VAV_ICU, VAV_PATRMS, VAV_LABS), Outpatient Healthcare (AHU-1), and Large Office (AirLoop Datacenter Basement) prototype buildings.

Assuming the humidifier is of electric steam type, the impact of added insulation is modeled by adding an electric heating coil to the affected air handling units (AHUs). When the humidifier is on, the electric coil is on. The coil outputs differ between the baseline and the advanced case to capture the impact of insulation on the steam dispersion assembly. In the baseline, the coil output causes the supply air temperature rise of $2.58^{\circ} \mathrm{F}$ (PNNL 2014). In the advanced case with humidifier insulation, the coil output causes the supply air temperature rise of $0.65^{\circ} \mathrm{F}$ (Wasner and Lundgreen, 2007).

\section{Impact of Preheat Coil Control}

Section 6.5.2.5 intends to avoid uncontrolled heat transfer from the preheat coil to the bypass air when AHUs are in cooling mode, including economizing mode. This heat transfer can occur on face and bypass coils even when the face dampers are completely closed. The requirements have an impact on systems in the Hospital (VAV_ER, VAV_OR, VAV_ICU, VAV_PATRMS, VAV_LABS) and Outpatient Healthcare (AHU-1) prototype buildings. To capture the impact of steam preheat coil control, a hot water coil is added to the affected AHUs.

In the baseline case, the hot water coil is on when the outdoor air temperature is below $50^{\circ} \mathrm{F}$ regardless of whether the AHU is in cooling or heating mode. When the hot water coil is on, it has a heating output of $8.5 \mathrm{Btu} / \mathrm{h}$ per cooling cfm for the operating room AHU and $3.0 \mathrm{Btu} / \mathrm{h}$ per cooling cfm 
for other medical area AHUs (PNNL 2014). In the advanced case, the hot water coil is only on when the outdoor air temperature is below $50^{\circ} \mathrm{F}$ and the AHU is in heating mode. The supply air temperature rise is calculated from the heating output and the airflow rate.

\section{Implementation Approach}

In EnergyPlus, heating coils located in the AHUs are controlled to a predefined temperature setpoint. This means that the heating output normally varies to satisfy the controlled temperature setpoint. This control method does not meet the requirement of modeling a constant heating output for a given system. The EMS is used to achieve the control strategy described above. When the added heating coil is on, the controlled temperature setpoint is reset based on the inlet node temperature and the air temperature rise.

\subsubsection{Addendum 90.1-2010au: Fan Power Limitation Adjustment Credits}

Addendum 90.1-2010au adds deductions to pressure drop credits specified in Table 6.5.3.1B of Standard 90.1-2010 (now Table 6.5.3.1-2 in Standard 90.1-2013), used to calculate the fan power limits for a system. The deductions apply to systems without any central heating or cooling device. Systems without a central cooling device are required to deduct 0.6 inches water column (in. w.c.) from the allowed fan pressure drop, systems without a central heating device are required to deduct 0.3 in. w.c. from the allowed fan pressure drop, and systems with a central electric resistance heating element are required to deduct 0.2 in. w.c. from the allowed fan pressure drop. Another requirement allows an adjustment for sound attenuation for fans in systems serving spaces with background noise criteria requirements, although this change does not affect the prototype building models.

All prototype buildings have central cooling coils but none of them have central electric resistance coils. Therefore, the new requirements only impact those prototype buildings without central heating coils. This applies to multi-zone VAV systems: Hospital, Large Hotel, Large Office, Medium Office, Outpatient Healthcare, Primary School, and Secondary School located in warm climates. To determine the systems that must take the fan pressure deduction, additional calculations are required. A central heating device is needed only when the mixed air temperature (MAT) is below the supply air temperature (SAT) setpoint at design conditions.

Assuming a return air temperature of $75^{\circ} \mathrm{F}$ and a supply air temperature of $55^{\circ} \mathrm{F}$, and using the heating design outdoor air temperature for each climate location, the critical outdoor air fraction at which mixed air temperature would be equal to the supply air temperature setpoint is calculated. If the modeled outdoor air fraction — calculated based on multi-zone ventilation and dynamic ventilation reset requirements - is larger than the critical outdoor air fraction calculated earlier, the MAT would be lower than the SAT and a heating coil is required. Accordingly, when a central heating coil is required, the fan pressure drop is reduced by 0.3 in. w.c. in the advanced models.

\subsubsection{Addendum 90.1-2010az: Cooling Tower Efficiency}

Addendum 90.1-2010az increases the minimum efficiency of open circuit axial fan cooling towers from 38.2 to $40.2 \mathrm{gpm} / \mathrm{hp}$ at rated conditions. Additionally, a note " $\mathrm{f}$ " is added to Table 6.8.1G (now Table 6.8.1-7 in Standard 90.1-2013) clarifying that the required minimum efficiency rating for all types of cooling towers applies to models with options and accessories that affect the thermal performance of the whole unit, and not just the base model. 
The addendum applies to the Hospital and Large Office prototype buildings that use water cooled chillers. The impact of footnote " $\mathrm{f}$ " to Table 6.8.1G (now Table 6.8.1-7 in Standard 90.1-2013) cannot be captured because the cooling towers in prototype building models do not account for add-ons that may impact the efficiency of the whole unit. The impact of addendum 90.1-2010az is captured by converting the efficiency (gpm/hp) to fan power based on the design flow rate and inputting the fan power into EnergyPlus.

\subsubsection{Addendum 90.1-2010ba: Door Switches}

Addendum 90.1-2010ba adds a new Section, 6.5.10, to Standard 90.1-2010 and requires doors opening to the outside, which do not close automatically, to have switches that connect to the HVAC system, such that the HVAC system is put into deep setback $\left(55^{\circ} \mathrm{F}\right.$ for heating and $90^{\circ} \mathrm{F}$ for cooling) automatically 5 minutes after the door is opened. Doors in spaces that are not being heated or cooled as well as loading dock doors are exempted. Operable doors, such as those that open to balconies in apartments and hotel guestrooms that are operated by the occupants for fresh air, are the types of doors targeted by the addendum. The addendum attempts to reduce the HVAC energy spent in satisfying the unintentional infiltration load from operable doors.

Apartments in the two apartment prototypes and guestrooms in the two hotel prototypes are likely to have doors opening to the outside that do not have automatic closing devices. To capture the impact of this addendum, several unknowns needed to be resolved:

1. the fraction of apartments and guestrooms in prototype buildings that have operable doors,

2. ambient conditions when doors are likely to be open,

3. the probability of operable doors being operated during favorable conditions,

4. the time for which doors stay open after conditions become unfavorable,

5. the time of day when doors may be open, and,

6. the fraction of door area that is open to the outdoor conditions.

The New Commercial Construction Characteristics (NC3) database ${ }^{1}$ (Richman et al. 2008) is used to determine the fraction of spaces with operable doors in the two apartment and the two hotel prototypes. The fractions are based on a review of groups of building plans. Of the plans reviewed for mid-rise apartment buildings, not all buildings had operable doors and balconies. Similarly, not all the guestrooms in a group of reviewed hotels had operable doors to the outside. To simulate savings from this addendum the following assumptions are made:

1. Assume that outdoor conditions are considered favorable between outdoor temperatures of $60^{\circ} \mathrm{F}$ and $80^{\circ} \mathrm{F}$.

2. Assume one-third of operable doors are opened when conditions are favorable.

\footnotetext{
${ }^{1}$ NC3 is a database developed by Pacific Northwest National Laboratory based on building characteristics taken from McGraw Hill commercial building plans submitted for bidding. The database includes over 160 buildings.
} 
3. Assume doors stay open for 1 hour after conditions become unfavorable.

4. Assume doors are allowed to be open only from 6 a.m. to 10 p.m. After 10 p.m., doors are unlikely to be operated.

5. Assume area of door opening is on average $25 \%$ of fully open. The doors are assumed to be 7 feet tall and 6 feet wide, a common sliding door dimension.

6. Assume doors are closed when the indoor temperature falls below $66^{\circ} \mathrm{F}$ or rises above $78^{\circ} \mathrm{F}$.

In the baseline models, the HVAC system continues to operate normally after the doors have been opened. In the advanced models, the thermostat is set back to $55^{\circ} \mathrm{F}$ for heating and $90^{\circ} \mathrm{F}$ for cooling 5 minutes after the door is opened. Table 5.9 summarizes the assumptions used in modeling addendum 90.1-2010ba.

Table 5.9. Prototype Building Properties and Assumptions for Modeling Door Switches

\begin{tabular}{|c|c|c|c|c|}
\hline \multirow[b]{2}{*}{ Assumptions } & \multicolumn{4}{|c|}{ Prototype Buildings } \\
\hline & $\begin{array}{l}\text { High-rise } \\
\text { Apartment }\end{array}$ & $\begin{array}{c}\text { Mid-rise } \\
\text { Apartment }\end{array}$ & Small Hotel & Large Hotel \\
\hline Number of buildings in the NC3 Database & 3 & 4 & 8 & 18 \\
\hline Fraction of operable doors in living areas & $36.7 \%$ & $11.6 \%$ & $0.7 \%$ & $9.6 \%$ \\
\hline $\begin{array}{l}\text { Fraction of doors operated when conditions are } \\
\text { favorable }\end{array}$ & 0.33 & 0.33 & 0.33 & 0.33 \\
\hline Fraction of door area that is open & $25 \%$ & $25 \%$ & $25 \%$ & $25 \%$ \\
\hline Operable door dimension & $7 \mathrm{ft} \times 6 \mathrm{ft}$ & $7 \mathrm{ft} \times 6 \mathrm{ft}$ & $7 \mathrm{ft} \times 6 \mathrm{ft}$ & $7 \mathrm{ft} \times 6 \mathrm{ft}$ \\
\hline Operable door opening area $\left(\mathrm{ft}^{2}\right)$ & 1.27 & 0.40 & 0.02 & 0.22 \\
\hline Operable door availability & $\begin{array}{l}6 \text { a.m. to } \\
10 \text { p.m. }\end{array}$ & $\begin{array}{l}6 \text { a.m. to } \\
10 \text { p.m. }\end{array}$ & $\begin{array}{l}6 \text { a.m. to } \\
10 \text { p.m. }\end{array}$ & $\begin{array}{l}6 \text { a.m. to } \\
10 \text { p.m. }\end{array}$ \\
\hline Building height (ft) & 100 & 40 & 38 & 63 \\
\hline Height difference (ft) & 50 & 20 & 19 & 31.5 \\
\hline Min indoor temp $\left({ }^{\circ} \mathrm{F}\right)$ & 66 & 66 & 66 & 66 \\
\hline Max indoor temp ( $\left.{ }^{\circ} \mathrm{F}\right)$ & 78 & 78 & 78 & 78 \\
\hline Min outdoor temp $\left({ }^{\circ} \mathrm{F}\right)$ & 60 & 60 & 60 & 60 \\
\hline Max outdoor temp $\left({ }^{\circ} \mathrm{F}\right)$ & 80 & 80 & 80 & 80 \\
\hline $\begin{array}{l}\text { Fraction of living spaces in prototypes that are } \\
\text { occupied }\end{array}$ & $100 \%$ & $100 \%$ & $65 \%$ & $65 \%$ \\
\hline
\end{tabular}

The ZoneVentilation:WindandStackOpenArea object in EnergyPlus is used to control infiltration from the operable door. This object allows the opening area to be defined and indoor and outdoor temperature limits to be established for the operation of the door, and takes into account the effect of wind and stack on the infiltration through the opening. The EMS is used to detect whether the door is open. If the door has been open for one time-step (the time-step for all models is longer than 5 minutes), the thermostat setback is enabled by changing the thermostat schedule.

\subsubsection{Addendum 90.1-2010bi: Air Conditioner and Heat Pump Efficiency}

Section 6.4.1.1 in Standard 90.1-2010 and its related tables include mandatory minimum efficiency values for HVAC equipment. Table 6.8.1A in Standard 90.1-2010 (now Table 6.8.1-1 in Standard 90.12013) applies to unitary air conditioners and condensing units and Table 6.8.1B (now Table 6.8.1-2 in Standard 90.1-2013) applies to unitary and applied heat pumps. Minimum efficiency values are provided 
for equipment with different cooling capacities and different manufacturing time periods. Addendum 90.1-2010bi increases the efficiency values for unitary air conditioners and heat pumps under 65,000 Btu/h cooling capacity manufactured on or after January 1, 2015. Table 5.10 shows the Standard 90.12010 values and the amended values from addendum 90.1-2010bi for this size equipment manufactured on or after January 1, 2015. Values not shown in the table remain the same as in Standard 90.1-2010.

Table 5.10. Unitary HVAC Equipment Efficiency ( $<65,000 \mathrm{Btu} / \mathrm{h})$

\begin{tabular}{|c|c|c|c|c|c|}
\hline Equipment Type & Size Category & $\begin{array}{c}\text { Heating } \\
\text { Section } \\
\text { Type } \\
\end{array}$ & $\begin{array}{c}\text { Subcategory or } \\
\text { Rating } \\
\text { Condition } \\
\end{array}$ & $\begin{array}{c}90.1-2010 \\
\text { Minimum } \\
\text { Efficiency } \\
\text { Before } \\
1 / 1 / 2015^{(a)}\end{array}$ & $\begin{array}{c}\text { Addendum 90.1- } \\
\text { 2010bi Minimum } \\
\text { Efficiency } \\
\text { As of } 1 / 1 / 2015\end{array}$ \\
\hline \multirow{2}{*}{$\begin{array}{l}\text { Air Conditioners, } \\
\text { Air-Cooled }\end{array}$} & \multirow[t]{2}{*}{$<65,000 \mathrm{Btu} / \mathrm{h}$} & \multirow[t]{2}{*}{ All } & Split System & 13.0 SEER & 13.0 SEER \\
\hline & & & Single Package & 13.0 SEER & 14.0 SEER \\
\hline \multirow{2}{*}{$\begin{array}{l}\text { Heat Pumps, Air- } \\
\text { Cooled (cooling } \\
\text { mode) }\end{array}$} & \multirow[t]{2}{*}{$<65,000 \mathrm{Btu} / \mathrm{h}$} & \multirow[t]{2}{*}{ All } & Split System & 13.0 SEER & 13.0 SEER \\
\hline & & & Single Package & 13.0 SEER & 14.0 SEER \\
\hline \multirow{2}{*}{$\begin{array}{l}\text { Heat Pumps, Air- } \\
\text { Cooled (heating } \\
\text { mode) }\end{array}$} & \multirow{2}{*}{$\begin{array}{c}<65,000 \mathrm{Btu} / \mathrm{h} \\
\text { (cooling capacity) }\end{array}$} & \multirow[t]{2}{*}{ All } & Split System & 7.7 HSPF & $8.2 \mathrm{HSPF}$ \\
\hline & & & Single Package & 7.7 HSPF & 8.0 HSPF \\
\hline
\end{tabular}

(a) HSPF is heating seasonal performance factor; SEER is seasonal energy efficiency ratio.

The changes are implemented in the advanced models by modifying a script routine that extracts the equipment cooling capacity and assigns the corresponding equipment efficiency based on that capacity. For the advanced models, higher efficiency values are applied for the applicable unit type and capacity. This affects the HVAC units in prototype buildings with unitary HVAC equipment, including the Small Office, Medium Office, Standalone Retail, Strip Mall, Primary School, Outpatient Healthcare, Small Hotel, Warehouse, Quick-service Restaurant, Full-service Restaurant, and Mid-rise Apartment. Only those systems with air conditioners and heat pumps having capacities smaller than $65,000 \mathrm{Btu} / \mathrm{h}$ are affected.

\subsubsection{Addendum 90.1-2010bk: PTAC Cooling Efficiency}

The current federal minimum cooling efficiency levels for standard-size packaged terminal air conditioners (PTACs) established by DOE rulemaking are lower than those for packaged terminal heat pumps (PTHPs). These requirements came into effect on October 8, 2012. Addendum 90.1-2010bk modifies Table 6.8.1D (now Table 6.8.1-4 in Standard 90.1-2013) by raising the minimum cooling efficiency requirements for standard-size PTACs manufactured on or after January 1, 2015, to the same level as the PTHPs.

Table 5.11 shows the change in PTAC efficiency required as per addendum 90.1-2010bk. 
Table 5.11. Standard-size PTAC Efficiency

\begin{tabular}{llcc}
\hline Equipment Type & Size Category & $\begin{array}{c}\text { Minimum Efficiency } \\
\text { Effective before 1/1/2015 }\end{array}$ & $\begin{array}{c}\text { Minimum Efficiency } \\
\text { Effective as of 1/1/2015 }\end{array}$ \\
\hline $\begin{array}{l}\text { PTAC } \\
\text { (cooling mode) }\end{array}$ & All Capacities & $13.8-(0.3 \times$ Cap/1000) EER & $14.0-(0.3 \times$ Cap/1000) EER \\
\hline
\end{tabular}

The addendum only applies to the Small Hotel prototype building, which has guestrooms and corridors served by PTACs. The addendum is modeled by assigning the higher efficiency level to the advanced models. The calculation of EnergyPlus COP from EER is shown in the Analysis of 90.1-2010 (Thornton et al. 2011).

\subsubsection{Addendum 90.1-10bs: Demand Controlled Ventilation}

Demand controlled ventilation (DCV) requirements were first introduced in Standard 90.1-2004. Since then, DCV requirements have become more stringent mainly by reducing the design occupancy threshold at which the requirements are triggered. Addendum 90.1-2010bs reduces the threshold at which DCV is required from $>40$ to $>25$ people per $1000 \mathrm{ft}^{2}$ and also lowers the minimum system outdoor air threshold from 1200 to $750 \mathrm{cfm}$. Due to the renumbering of sections in Section 6.4, the DCV requirements now appear in Section 6.4.3.8.

The impact of this addendum is captured by first identifying prototype buildings with spaces that have design occupancy of more than 25 people per $1000 \mathrm{ft}^{2}$ and meeting other DCV requirements. Spaces meeting all the DCV requirements and the lower design occupancy threshold are identified in Large Hotel, Primary School, and Secondary School prototype buildings.

For the Primary and Secondary School prototypes, DCV controllers are implemented for the classroom pods, which previously did not require them. For the Large Hotel prototype, DCV controller has been implemented for the multi-zone VAV system, but new spaces are added to the controller as part of the new requirements. DCV is implemented in EnergyPlus by using a mechanical controller to control turn down of the outdoor air intake (based on occupancy) in spaces required to have DCV. Only the people component of the total outdoor air intake is allowed to be reduced by the DCV controller. Even though DCV controls are added to new spaces, DCV will be enabled only if it is required for the particular prototype building model in a given climate zone.

DCV is not required in the presence of an energy recovery ventilator (ERV). A preliminary simulation is conducted to determine whether ERV is required for each prototype building model. After the final ERV and DCV assignments are made and the system layout is finalized, the final sizing and annual runs are conducted.

\subsubsection{Addendum 90.1-2010bt and Addendum 90.1-2010cy: Energy Recovery Ventilation}

Table 6.5.6.1 in Standard 90.1-2010 specified energy recovery requirements as a function of percent outdoor air and design supply fan airflow. The requirements were for systems with outdoor air ventilation ratios above $30 \%$. Many buildings operate with ventilation ratios below $30 \%$. Addendum 90.1-2010bt establishes energy recovery for outdoor ventilation rates above $10 \%$ in climate zones $1 \mathrm{~A}, 2 \mathrm{~A}$, 3A, 4A, 5A, 6A, 6B, 7, and 8. Additionally, the requirements for zones 3B, 3C, 4B, 4C, and 5B for 
systems with outdoor ventilation rates above $70 \%$ are removed because it was determined that energy recovery would not be cost-effective for ventilation systems that do not operate continuously.

Addendum 90.1-2010cy separates the energy recovery requirements for ventilation systems operating less than 8,000 hours per year and more than 8,000 hours per year in two tables: Table 6.5.6.1-1 and 6.5.6.1-2 of Standard 90.1-2013. Table 6.5.6.1-1 carries the requirements introduced by addendum 90.12010bt, whereas Table 6.5.6.1-2 includes requirements for ventilation systems running more than 8,000 hours per year, enabling the requirements that were removed by addendum 90.1-2010bt to be reintroduced together with the new requirements.

Table 5.12 and Table 5.13 show the requirements introduced by addendum 90.1-2010bt and addendum 90.1-2010cy. Blank cells in Table 5.12 indicate that the requirement did not change from Standard 90.1-2010.

Table 5.12. New ERV Requirements for Ventilation Systems Operating Less than 8000 Hours per Year

\begin{tabular}{|c|c|c|c|c|}
\hline \multirow{3}{*}{ Climate Zone } & \multicolumn{4}{|c|}{ \% Outdoor Air at Full Design Airflow Rate } \\
\hline & $\begin{array}{c}\geq 10 \% \\
\text { and } \\
<20 \%\end{array}$ & $\begin{array}{c}\geq 20 \% \\
\text { and } \\
<30 \%\end{array}$ & $\begin{array}{c}\geq 70 \% \\
\text { and } \\
<80 \%\end{array}$ & $\geq 80 \%$ \\
\hline & \multicolumn{4}{|c|}{$\begin{array}{c}\text { Design Supply Fan Airflow Rate } \\
\text { (cfm) }\end{array}$} \\
\hline $3 B, 3 C, 4 B, 4 C, 5 B$ & NR & NR & NR & NR \\
\hline $1 \mathrm{~B}, 2 \mathrm{~B}, 5 \mathrm{C}$ & NR & NR & & \\
\hline $6 \mathrm{~B}$ & $\geq 28,000$ & $\geq 26,500$ & & \\
\hline 1A, 2A, 3A, 4A, 5A, 6A & $\geq 26,000$ & $\geq 16,000$ & & \\
\hline 7,8 & $\geq 4500$ & $\geq 4000$ & & \\
\hline
\end{tabular}

Table 5.13 ERV Requirements for Ventilation Systems Operating Greater than 8,000 Hours per Year

\begin{tabular}{|c|c|c|c|c|c|c|c|c|}
\hline \multirow{3}{*}{ Climate Zone } & \multicolumn{8}{|c|}{ \% Outdoor Air at Full Design Airflow Rate } \\
\hline & $\begin{array}{c}\geq 10 \% \\
\text { and } \\
<20 \%\end{array}$ & $\begin{array}{c}\geq 20 \% \\
\text { and } \\
<30 \%\end{array}$ & $\begin{array}{c}\geq 30 \% \\
\text { and } \\
<40 \%\end{array}$ & $\begin{array}{c}\geq 40 \% \\
\text { and } \\
<50 \%\end{array}$ & $\begin{array}{c}\geq 50 \% \\
\text { and } \\
<60 \%\end{array}$ & $\begin{array}{c}\geq 60 \% \\
\text { and } \\
<70 \%\end{array}$ & $\begin{array}{c}\geq 70 \% \\
\text { and } \\
<80 \%\end{array}$ & $\geq 80 \%$ \\
\hline & \multicolumn{8}{|c|}{$\begin{array}{c}\text { Design Supply Fan Airflow Rate } \\
\text { (cfm) }\end{array}$} \\
\hline $3 \mathrm{C}$ & NR & NR & NR & NR & NR & NR & NR & NR \\
\hline 1B, 2B, 3B, 4C, 5C & NR & $\geq 19500$ & $\geq 9000$ & $\geq 5000$ & $\geq 4000$ & $\geq 3000$ & $\geq 1500$ & $>0$ \\
\hline $1 \mathrm{~A}, 2 \mathrm{~A}, 3 \mathrm{~A}, 4 \mathrm{~B}, 5 \mathrm{~B}$ & $\geq 2500$ & $\geq 2000$ & $\geq 1000$ & $\geq 500$ & $>0$ & $>0$ & $>0$ & $>0$ \\
\hline $4 \mathrm{~A}, 5 \mathrm{~A}, 6 \mathrm{~A}, 6 \mathrm{~B}, 7,8$ & $>0$ & $>0$ & $>0$ & $>0$ & $>0$ & $>0$ & $>0$ & $>0$ \\
\hline
\end{tabular}

ERV requirements are not applied to the two apartment prototypes or the Small Hotel prototype even though they meet the trigger for the requirement because ERVs are not available for these small systems. Based on the system sizing information from the EnergyPlus simulation, each air system of the other 13 prototype buildings in each climate location is checked to determine whether energy recovery is applicable. Other energy recovery modeling details have been described previously in the Analysis of 90.1-2010 (Thornton et al. 2011). 


\subsubsection{Addendum 90.1-2010cb: Optimum Start}

Addendum 90.1-2010cb introduces several changes to the setback control (Section 6.4.3.3.2) and optimum start control requirements (Section 6.4.3.3.3) in Standard 90.1-2010. New setback control requirements include the following: heating and cooling setback is required in all climate zones, heating setback is required to be at least $10^{\circ} \mathrm{F}$ below occupied heating setpoint, cooling setback is required to be at least $5^{\circ} \mathrm{F}$ above occupied cooling setpoint, and radiant heating systems are required to have a setback of at least $4^{\circ} \mathrm{F}$ below occupied heating setpoint. New optimum start control requirements include the following: removal of the 10,000 cfm threshold, requiring optimum start for only those systems with direct digital control (DDC) and setback control requirements, and requiring the control algorithm to be a function of outside air temperature and of floor temperature for radiant floor systems.

Because optimum start is now required for systems with DDC instead of for systems with a minimum of 10,000 cfm of design supply air, all systems in all prototype buildings are reexamined to determine whether DDC would be required for the system. Another addendum, 90.1-2010aa, introduced new requirements that clearly spelled out the situations in which DDC is required. This addendum was assumed to not have an energy impact because DDC by itself is assumed to not save energy in the models. The requirements of addendum $90.1-2010 \mathrm{cb}$ do interact with the requirements of addendum 90.1-2010aa when considering savings from 90.1-2010cb.

Addendum 90.1-2010aa adds a new Section, 6.4.3.10, to Standard 90.1-2010 for DDC with three parts: 1) DDC applications that require DDC for three new building situations and five existing building situations; 2) new requirements for DDC controls to have four capabilities-monitor zone and system demand for five parameters, transfer zone and system demand information to appropriate controllers, automatically detect those zones and systems that may be excessively driving the reset logic and generate an alarm to the system operator, and allow operator to remove zones from the reset algorithm (addendum 90.1 2010s also required the last two items for VAV static pressure reset-placing these requirements in a mandatory DDC section expands their scope to all resets, including chilled water and supply air); and 3) a requirement for DDC trending and graphically displaying input and output. With the clarity added for when DDC is required, it is possible to determine systems in the prototype models that are required to have DDC.

Table 5.14 lists systems in prototype building models required to have DDC controls per addendum 90.1-2010aa. These systems are not required to run continuously. Only packaged single-zone systems in the Standalone Retail prototype require DDC due to the requirements of addendum 90.1-2010aa; all other systems would have required DDC to operate and are assumed to have DDC in all models. 
Table 5.14. Systems in Prototype building Models Requiring DDC and Setback Controls in Standard 90.1-2013

\begin{tabular}{ll}
\hline Prototypes with DDC & Systems with Setback Controls and DDC \\
\hline Highrise Apartment & AirLoop Office DXAC Heat Pump \\
Hospital & None \\
Large Hotel & None \\
Large Office & CAV_BAS, VAV_BOT WITH REHEAT, VAV_mid WITH REHEAT, \\
& VAV_top WITH REHEAT \\
Medium Office & All systems \\
Outpatient Healthcare & All systems \\
Standalone Retail & All systems \\
Primary School & All systems \\
Secondary School & All systems \\
\hline
\end{tabular}

The new setback control requirements are captured as follows:

1. Heating and cooling setback are expanded to all climate zones. In Standard 90.1-2010 models, heating setback was exempt in climate zone 1 and cooling setback was required only in climate zones 1b, 2b, and 3b. Setback controls are applied only to systems that do not run continuously.

2. Optimum start controls are applied to those systems in Standard 90.1-2013 prototype building models that are required to have DDC and have setback controls regardless of system airflow. In the baseline models, standard optimum start control is applied only if the design fan airflow rate is higher than $10,000 \mathrm{cfm}$. The standard optimum start control does not include the effect of outside air temperature on the system start time.

3. For Standard 90.1-2013, the optimum start control algorithm is modified to include outside air temperature in calculating how the control is operated. The EMS within EnergyPlus is used to detect the outside air temperature. Based on the outside air temperature, the time at which the system should turn on to reach the occupied setpoint is determined. If the system is required to start 2 hours prior to the occupied thermostat setpoint, then the thermostat setpoint goes through two steps. If the system is required to start only 1 hour prior to the occupied setpoint, then the thermostat setpoint goes through just one step. In real buildings, optimum start controls could be based on a learning algorithm that starts the building optimally given the outdoor air temperature, space temperature, and the time before occupied setpoint. Figure 5.3 shows an example of how the optimum start control functions on a warm morning. The control operation is fully described in Enhancements to ASHRAE Standard 90.1 Prototype Building Models (PNNL 2014). 


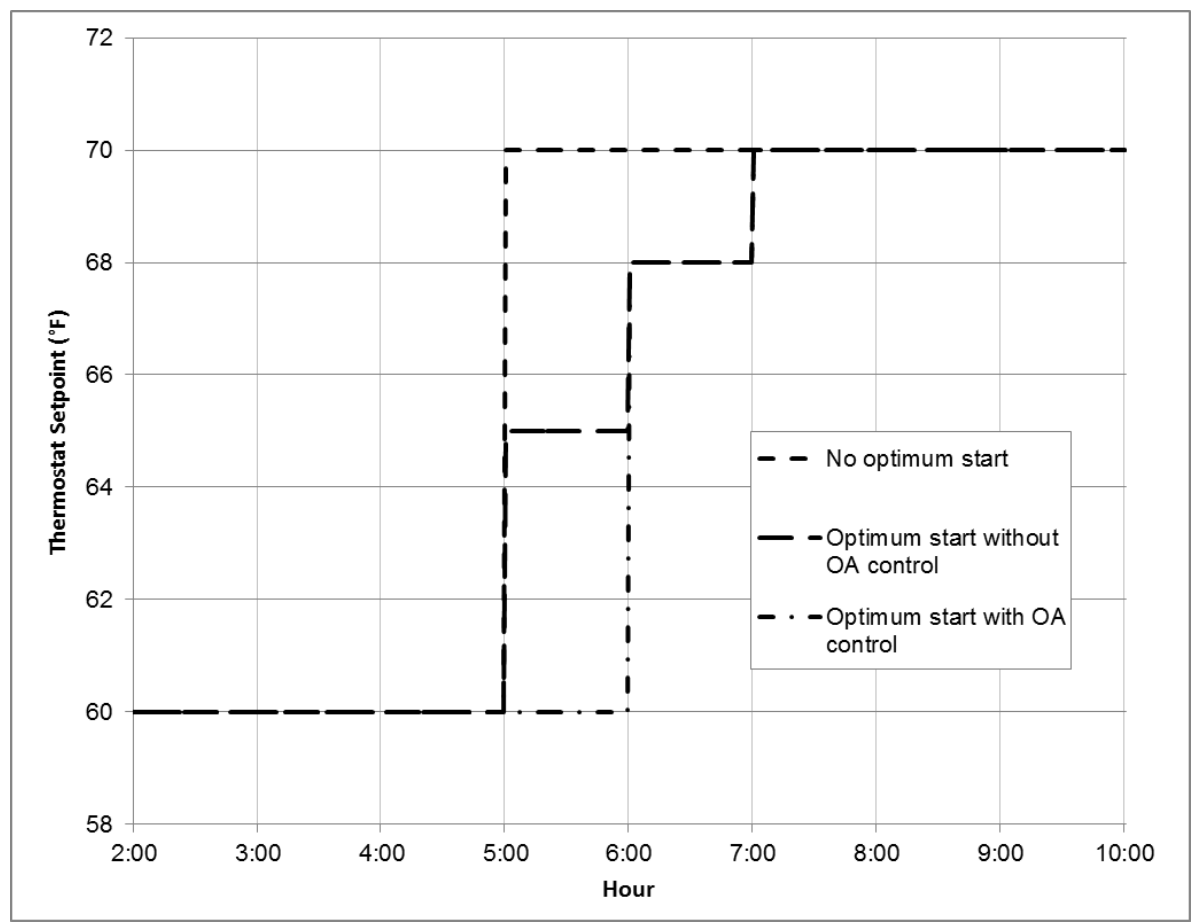

Figure 5.3. Example of Optimum Start Control Operation for a Warm Morning

\subsubsection{Addendum 90.1-10ch: Chiller Efficiency}

Addendum 90.1-2010ch changes the minimum efficiency requirements for air- and water-cooled chillers in Table 6.8.1C of Standard 90.1-2010 (now Table 6.8.1-3 of Standard 90.1-2013). Table 5.15 shows the minimum efficiency requirements, in terms of COP, for water-cooled positive displacement chillers, water-cooled centrifugal chillers, and air-cooled chillers. 
Table 5.15. Efficiency in COP for Chillers

\begin{tabular}{|c|c|c|c|c|c|c|c|c|}
\hline \multirow[b]{3}{*}{$\begin{array}{l}\text { Size } \\
\text { (tons) }\end{array}$} & \multicolumn{4}{|c|}{ Standard 90.1-2010 } & \multicolumn{4}{|c|}{ Addendum 90.1-2010ch } \\
\hline & \multicolumn{2}{|c|}{ Path A } & \multicolumn{2}{|c|}{ Path B } & \multicolumn{2}{|c|}{ Path A } & \multicolumn{2}{|c|}{ Path B } \\
\hline & $\begin{array}{c}\text { Full } \\
\text { Load }\end{array}$ & $\begin{array}{c}\text { Part } \\
\text { Load }\end{array}$ & $\begin{array}{c}\text { Full } \\
\text { Load }\end{array}$ & $\begin{array}{l}\text { Part } \\
\text { Load }\end{array}$ & $\begin{array}{c}\text { Full } \\
\text { Load }\end{array}$ & $\begin{array}{c}\text { Part } \\
\text { Load }\end{array}$ & $\begin{array}{c}\text { Full } \\
\text { Load }\end{array}$ & $\begin{array}{l}\text { Part } \\
\text { Load }\end{array}$ \\
\hline \multicolumn{9}{|c|}{ Water-cooled Positive Displacement Chillers } \\
\hline$<75$ & 4.51 & 5.58 & 4.39 & 5.86 & 4.69 & 5.86 & 4.51 & 7.03 \\
\hline $75-150$ & 4.54 & 5.72 & 4.45 & 6 & 4.88 & 6.28 & 4.69 & 7.18 \\
\hline $150-300$ & 5.17 & 6.06 & 4.9 & 6.51 & 5.33 & 6.51 & 5.17 & 7.99 \\
\hline $300-600$ & 5.67 & 6.51 & 5.5 & 7.18 & 5.76 & 6.76 & 5.63 & 8.58 \\
\hline$>300$ & 5.67 & 6.51 & 5.5 & 7.18 & 6.28 & 7.03 & 6.01 & 9.25 \\
\hline \multicolumn{9}{|c|}{ Water-cooled Centrifugal Chillers } \\
\hline$<150$ & 5.55 & 5.9 & 5.5 & 7.81 & 5.76 & 6.39 & 5.06 & 7.99 \\
\hline $150-300$ & 5.55 & 5.9 & 5.5 & 7.81 & 5.76 & 6.39 & 5.54 & 8.79 \\
\hline $300-400$ & 6.1 & 6.4 & 5.86 & 8.79 & 6.28 & 6.76 & 5.91 & 9.02 \\
\hline $400-600$ & 6.1 & 6.4 & 5.86 & 8.79 & 6.28 & 7.03 & 6.01 & 9.25 \\
\hline$>600$ & 6.17 & 6.52 & 5.96 & 8.79 & 6.28 & 7.03 & 6.01 & 9.25 \\
\hline \multicolumn{9}{|c|}{ Air-cooled Chillers } \\
\hline$<150$ & 2.8 & 3.66 & NA & NA & 2.96 & 4.01 & 2.84 & 4.63 \\
\hline $150-300$ & 2.8 & 3.74 & NA & NA & 2.96 & 4.1 & 2.84 & 4.72 \\
\hline
\end{tabular}

This addendum involves both full-load and part-load efficiency changes. Because of the lack of reliable performance curves used to model part-load efficiency, only the impact of full-load efficiency changes is captured. This is the same approach used previously for addendum $90.1-2007 \mathrm{~m}$ when modeling the Standard 90.1-2010 requirements in the Analysis of 90.1-2010 (Thornton et al. 2011).

The Secondary School and Large Hotel prototypes use air-cooled chillers, while the Hospital and Large Office prototypes use water-cooled chillers. Path A is followed for all four prototype buildings. The full-load efficiency changes are implemented through the sizing routine by changing the capacity thresholds and corresponding efficiency levels.

\subsubsection{Addendum 90.1-2010cz: Residential-size Boiler Efficiency}

Addendum 90.1-2010cz increases the minimum efficiency for boilers with capacities less than 300,000 Btu/h by updating Table 6.8.1F in Standard 90.1-2010 (now Table 6.8.1-6 in Standard 90.12013). This increase in efficiency reflects the minimum federally mandated equipment efficiency for these types of boilers. Efficiency improvements in terms of annual fuel utilization efficiency (AFUE), combustion efficiency, or thermal efficiency are seen for gas-fired and oil-fired boilers with capacities less than 300,000 Btu/h. Boilers of this size are typically found in residential building applications. Table 5.16 shows the boiler efficiency requirements modified by addendum 90.1-2010cz. 
Table 5.16. Boiler Efficiency Requirements in Addendum 90.1-2010cz

\begin{tabular}{|c|c|c|c|c|c|}
\hline \multirow[b]{2}{*}{$\begin{array}{l}\text { Equipment } \\
\text { Type }\end{array}$} & \multirow[b]{2}{*}{ Subcategory } & \multirow[b]{2}{*}{ Size Category (Input) } & \multirow{2}{*}{$\begin{array}{c}\text { Minimum } \\
\text { Efficiency Before } \\
\text { Addendum } 90.1- \\
2010 \mathrm{cz} \\
\text { As of } 3 / 2 / 2010\end{array}$} & \multicolumn{2}{|c|}{$\begin{array}{c}\text { Minimum Efficiency After } \\
\text { Addendum 90.1-2010cz }\end{array}$} \\
\hline & & & & $\begin{array}{c}\text { After } \\
\text { Addendum } \\
\text { 90.1-2010cz }\end{array}$ & $\begin{array}{c}\text { As of } \\
3 / 2 / 2020\end{array}$ \\
\hline \multirow{6}{*}{$\begin{array}{l}\text { Boilers, Hot } \\
\text { Water }\end{array}$} & \multirow[t]{3}{*}{ Gas Fired } & $<300,000 \mathrm{Btu} / \mathrm{h}$ & $80 \%$ AFUE & $82 \%$ AFUE & $82 \%$ AFUE \\
\hline & & $\begin{array}{l}\geq 300,000 \mathrm{Btu} / \mathrm{h} \text { and } \\
<2,500,000 \mathrm{Btu} / \mathrm{h}\end{array}$ & $80 \% \mathrm{Et}$ & $80 \%$ Et & $80 \% \mathrm{Et}$ \\
\hline & & $>2,500,000 \mathrm{Btu} / \mathrm{h}$ & $82 \%$ Ec & $82 \%$ Ec & $82 \%$ Ec \\
\hline & \multirow[t]{3}{*}{ Oil Fired } & $<300,000 \mathrm{Btu} / \mathrm{h}$ & $80 \%$ AFUE & 84\% AFUE & 84\% AFUE \\
\hline & & $\begin{array}{l}\geq 300,000 \mathrm{Btu} / \mathrm{h} \text { and } \\
<2,500,000 \mathrm{Btu} / \mathrm{h}\end{array}$ & $82 \%$ Et & $82 \%$ Et & $82 \% \mathrm{Et}$ \\
\hline & & $>2,500,000 \mathrm{Btu} / \mathrm{h}$ & $84 \%$ Ec & $84 \%$ Ec & $84 \%$ Ec \\
\hline \multirow{8}{*}{$\begin{array}{l}\text { Boilers, } \\
\text { Steam }\end{array}$} & Gas Fired & $<300,000 \mathrm{Btu} / \mathrm{h}$ & $75 \%$ AFUE & $80 \%$ AFUE & $80 \%$ AFUE \\
\hline & \multirow{2}{*}{$\begin{array}{l}\text { Gas-Fired all, } \\
\text { except Natural } \\
\text { Draft }\end{array}$} & $\begin{array}{l}\geq 300,000 \mathrm{Btu} / \mathrm{h} \text { and } \\
<2,500,000 \mathrm{Btu} / \mathrm{h}\end{array}$ & $79 \% \mathrm{Et}$ & $79 \% \mathrm{Et}$ & $79 \% \mathrm{Et}$ \\
\hline & & $>2,500,000 \mathrm{Btu} / \mathrm{h}$ & $79 \% \mathrm{Et}$ & $79 \% \mathrm{Et}$ & $79 \% \mathrm{Et}$ \\
\hline & \multirow[t]{2}{*}{$\begin{array}{l}\text { Gas Fired- } \\
\text { Natural Draft }\end{array}$} & $\begin{array}{l}\geq 300,000 \mathrm{Btu} / \mathrm{h} \text { and } \\
<2,500,000 \mathrm{Btu} / \mathrm{h}\end{array}$ & $77 \% \mathrm{Et}$ & $77 \% \mathrm{Et}$ & $79 \% \mathrm{Et}$ \\
\hline & & $>2,500,000 \mathrm{Btu} / \mathrm{h}$ & $77 \% \mathrm{Et}$ & $77 \% \mathrm{Et}$ & $79 \% \mathrm{Et}$ \\
\hline & \multirow[t]{3}{*}{ Oil Fired } & $<300,000 \mathrm{Btu} / \mathrm{h}$ & 80\% AFUE & $82 \%$ AFUE & $82 \%$ AFUE \\
\hline & & $\begin{array}{l}\geq 300,000 \mathrm{Btu} / \mathrm{h} \text { and } \\
<2,500,000 \mathrm{Btu} / \mathrm{h}\end{array}$ & $81 \%$ Et & $81 \%$ Et & $81 \% \mathrm{Et}$ \\
\hline & & $>2,500,000 \mathrm{Btu} / \mathrm{h}$ & $81 \% \mathrm{Et}$ & $81 \% \mathrm{Et}$ & $81 \% \mathrm{Et}$ \\
\hline
\end{tabular}

The following prototypes use gas-fired hot water boilers: Large Office, Primary School, Secondary School, Outpatient Healthcare, Hospital, and Large Hotel. There are no oil-fired or steam boilers in any of the prototype buildings. Only the Outpatient Healthcare prototype building has boilers smaller than 300,000 Btu/h.

The efficiency of gas-fired hot water boilers smaller than 300,000 Btu/h is increased from $80 \%$ AFUE to $82 \%$ AFUE by addendum 90.1-2010cz. To capture this impact, the efficiency must be expressed in terms of thermal efficiency for inputting into EnergyPlus. AFUE is similar to SEER and represents average annual efficiency. To calculate the thermal efficiency from AFUE, jacket losses must be subtracted. Jacket losses of up to $0.75 \%$ are allowed for furnaces smaller than $225,000 \mathrm{Btu} / \mathrm{h}$. This assumption is used for boilers smaller than $300,000 \mathrm{Btu} / \mathrm{h}$. Thus, the updated thermal efficiency as per addendum $90.1-2010 \mathrm{cz}$ is calculated to be $81.25 \%$.

The new efficiency is input using the sizing routine that detects the size of the boiler after the sizing run is complete, and provides the appropriate efficiency for the annual run. Note that the higher boiler efficiency is applied to the Standard 90.1-2013 models as well as the Standard 90.1-2010 models because addendum 90.1-2010cz introduces federally mandated requirements that do not provide credit to Standard 90.1-2013.

\subsubsection{Addendum 90.1-2010di: Humidity Controls}

Addendum 90.1-2010di modifies Section 6.4.3.7 in Standard 90.1-2010 (now Section 6.4.3.6 in Standard 90.1-2013) by prohibiting the use of fossil fuel and electricity for humidification above $30 \%$ 
relative humidity (RH) and dehumidification below $60 \% \mathrm{RH}$, except in special circumstances. A deadband of at least $10 \%$ is required when a specific humidity level needs to be maintained for special spaces. Addendum 90.1-2010di also modifies Section 6.5.2.3 in Standard 90.1-2010 by requiring at least 75\% of the annual energy used for reheat to be from recovered or site-generated solar energy when specific humidity levels are set and dehumidification control is needed. Other systems that dehumidify and reheat but do not maintain specific humidity levels are required to have $90 \%$ of the annual energy used for reheat to be recovered or sourced from site-generated solar energy.

In prototype building models, humidity control is required in the Hospital and Outpatient Healthcare prototype buildings and also in systems serving the data center zones in the Large Office prototype building. The changes in Section 6.5.2.3 due to addendum 90.1-2010di do not have an impact because exception (a) to Section 6.5.2.3 allows reheating if the airflow is supplied to meet ventilation requirement, and this is true for the particular prototype building models.

The changes to Section 6.4.3.7 from addendum 90.1-2010di affect all air systems with humidity control in the Hospital and Outpatient Healthcare prototype buildings. The air system for the data center in the Large Office prototype is not affected because it serves only one zone that already has a setpoint of $30 \%$ RH for humidification.

To implement the changes from addendum 90.1-2010di, two changes are applied:

1. The lower humidification limit is set to $30 \% \mathrm{RH}$ for the advanced models, except for the ICU zone in the Hospital prototype, where it is set to $35 \%$ RH considering that some of the zones under the ICU system are for burn units with $40 \% \mathrm{RH}$ requirement. For the baseline models, the lower humidification limit is left at $40 \% \mathrm{RH}$.

2. For advanced models, the AHU's humidity control strategy is changed to the warmest zone for humidification and the coldest zone for dehumidification. In baseline models, the humidity control strategy continues to be based on pre-defined critical zones.

\subsubsection{Addendum 90.1-2010dv: Chiller/Boiler Fluid Flow Isolation}

Addendum 90.1-2010dv modifies Section 6.5.4.2 of Standard 90.1-2010 to clarify that when multiple chillers or boilers are used, fluid flow through the chillers or boilers that are not operating should be automatically shut off. Addendum 90.1-2010dv also requires that when pumps are used to serve multiple chillers or boilers, the number of pumps shall be equal to the number of chillers or boilers and the pumps will be cycled on and off with the chiller or boiler they serve.

The Hospital and Large Office prototypes are each modeled with two chillers. Other prototypes having chillers or boilers are modeled with only a single piece of equipment. A single constant speed pump serves the two chillers in both the 90.1-2010 Hospital and Large Office prototypes. To model the requirements of addendum 90.1-2010dv, two constant speed pumps (one for each chiller) are used in the advanced models. The pumps cycle on and off with the operation of the chiller they are serving, thus meeting both the requirements of addendum 90.1-2010dv. 


\subsubsection{Power}

\subsubsection{Addendum 90.1-2010bf: Automatic Receptacle Control}

Addendum 90.1-2010bf adds to the requirements previously established by addenda 90.1-2007bs and 90.1-2007cs. This addendum modifies Section 8.4.2 of Standard 90.1-2010 and adds more spaces to the requirement: conference rooms, print/copy rooms, break rooms, and classrooms other than computer classrooms. Open offices required receptacle controls in Standard 90.1-2010, and appear to have been taken off the list of spaces in this addendum; however, the new requirement requires control of individual workstations, which are interpreted as workstations in open offices.

There are other changes made by addendum 90.1-201bf to the original requirement. Independent controls are required for every 5,000 $\mathrm{ft}^{2}$ instead of 25,000 $\mathrm{ft}^{2}$ in Standard 90.1-2010 and manual override lasting for 2 hours is allowed. Receptacles are required to be uniformly distributed throughout the space and permanently labeled to visually differentiate the controlled receptacles. These additions are intended to improve compliance and increase energy savings, but compliance rate improvements are not captured in the prototype building models. Occupancy-controlled turn-off is required to turn off power to the receptacle within 20 minutes, instead of 30 minutes in Standard 90.1-2010. Definitive data for the difference in energy savings between a 30- and 20-minute turn off could not be found in the literature and the potential energy savings from this change are not captured in the prototype building models.

The following prototype buildings include spaces that are affected by the new receptacle control requirements: Large Hotel, Small Hotel, Hospital, Medium Office, Large Office, Small Office, Standalone Retail, Full-service Restaurant, Primary School, Secondary School, Outpatient Healthcare, and Warehouse.

Because occupancy sensors are required by lighting control requirements in the new spaces added by addendum 90.1-2010bf, it is assumed that the same occupancy sensors would be used to meet the receptacle control requirement. The addition of new spaces to the receptacle control requirement is captured by following the steps below:

1. The area of each space type in each prototype is determined using the NC3 database. Table 5.17 shows the area fractions for spaces added by addendum 90.1-201bf.

2. The time each space type is unoccupied during normally occupied hours is found. Table 5.18 shows the unoccupied fraction during regularly occupied hours. This fraction is the ratio of the time a space is unoccupied during regular hours. For example, a classroom may be unoccupied during lunch time (12 noon to 1 p.m.), which is within the regular business hours (8 a.m. to 5 p.m.).

3. The fraction of plug-in equipment that is likely to be plugged into a controlled receptacle in each space type is calculated. Table 5.18 shows the fraction of equipment that could be turned off using occupancy sensors. For example, computer monitors could be turned off, but the computers are likely to be plugged into uncontrolled receptacles. The equipment makeup from the Advanced Energy Design Guides is used to determine the equipment that can be unplugged. A diversity factor is added to account for equipment that could be turned off but is not plugged into a controlled receptacle.

The factors and area fractions are combined to produce two reduction fractions, one for occupied periods and another for unoccupied periods, which will be applied to the occupied and unoccupied periods in the 
equipment schedule for that space. The two factors for the baseline and advanced models are shown in Table 5.19.

Table 5.17. Area Fractions for Space Types Added by Addendum 90.1-2010bf

\begin{tabular}{|c|c|c|c|}
\hline \multirow[b]{3}{*}{ Prototype } & \multicolumn{3}{|c|}{ Space/Prototype Area Fraction } \\
\hline & & & Conference \\
\hline & Classroom & Break Room & Room \\
\hline Large Hotel & $0.60 \%$ & $3.10 \%$ & $5.20 \%$ \\
\hline Small Hotel ${ }^{(\mathrm{a})}$ & $0.00 \%$ & $100 \%$ & $100 \%$ \\
\hline Hospital & $0.25 \%$ & $1.24 \%$ & $2.16 \%$ \\
\hline Large Office & $0.38 \%$ & $0.23 \%$ & $1.55 \%$ \\
\hline Medium Office & $0.50 \%$ & $1.80 \%$ & $5.20 \%$ \\
\hline Standalone Retail & $0.40 \%$ & $1.10 \%$ & $0.10 \%$ \\
\hline Full-service Restaurant & $0.00 \%$ & $0.70 \%$ & $0.00 \%$ \\
\hline Small Office & $0.00 \%$ & $2.00 \%$ & $8.00 \%$ \\
\hline Warehouse & $0.00 \%$ & $2.00 \%$ & $8.00 \%$ \\
\hline Primary School & $48.44 \%$ & $0.13 \%$ & $0.51 \%$ \\
\hline Secondary School & $35.28 \%$ & $0.11 \%$ & $0.43 \%$ \\
\hline Outpatient HealthCare & $0.00 \%$ & $2.93 \%$ & $0.82 \%$ \\
\hline \multicolumn{4}{|c|}{$\begin{array}{l}\text { (a) Small Hotel has separate zones and equipment schedules for the break } \\
\text { room and conference room space types. These spaces are assigned } \\
100 \% \text { area fraction because the reduction fraction from receptacle } \\
\text { control will be applied only to the equipment schedules for those zones }\end{array}$} \\
\hline
\end{tabular}

Table 5.18. Factors Used to Calculate Reduction Fraction for Equipment Schedule

\begin{tabular}{lccc}
\hline Factor & Classroom & Break Room & Conference Room \\
\hline Unoccupied fraction during occupied hours & 0.32 & 0.15 & 0.33 \\
Fraction of plug loads that could be turned off & 0.55 & 0.37 & 0.45 \\
Diversity factor & 0.75 & 0.75 & 0.75 \\
\hline
\end{tabular}


Table 5.19. Reduction Factors for Baseline and Advanced Models

\begin{tabular}{|c|c|c|c|c|}
\hline \multirow[b]{2}{*}{ Prototype } & \multicolumn{2}{|c|}{ Standard 90.1-2010 } & \multicolumn{2}{|c|}{ Standard 90.1-2013 } \\
\hline & $\begin{array}{c}\text { Occupied Hours } \\
\text { Reduction } \\
\text { Fraction }\end{array}$ & $\begin{array}{l}\text { Unoccupied Hours } \\
\text { Reduction Fraction }\end{array}$ & $\begin{array}{c}\text { Occupied Hours } \\
\text { Reduction } \\
\text { Fraction }\end{array}$ & $\begin{array}{c}\text { Unoccupied } \\
\text { Hours Reduction } \\
\text { Fraction }\end{array}$ \\
\hline Large Hotel & 0.9604 & 0.7938 & 0.9524 & 0.7652 \\
\hline Small Hotel - Private Office ${ }^{(a)}$ & 0.9258 & - & 0.9258 & - \\
\hline Small Hotel - Break Room & 1.0000 & 1.0000 & 0.9584 & 0.7228 \\
\hline Small Hotel - Conference Room & 1.0000 & 1.0000 & 0.8873 & 0.6625 \\
\hline Fast Food Restaurant & 0.9989 & 0.9951 & 0.9989 & 0.9951 \\
\hline Retail Strip Mall & 0.9963 & 0.9831 & 0.9963 & 0.9831 \\
\hline High-rise Apartment & 0.9258 & 0.6625 & 0.9258 & 0.6625 \\
\hline Mid-rise Apartment & 0.9258 & 0.6625 & 0.9258 & 0.6625 \\
\hline Hospital & 0.9773 & 0.8849 & 0.9740 & 0.8732 \\
\hline Large Office & 0.9515 & 0.7444 & 0.9491 & 0.7369 \\
\hline Medium Office & 0.9604 & 0.7938 & 0.9531 & 0.7692 \\
\hline Retail Standalone & 0.9983 & 0.9919 & 0.9972 & 0.9869 \\
\hline Sit Down Restaurant & 0.9992 & 0.9963 & 0.9989 & 0.9943 \\
\hline Small Office & 0.9694 & 0.8515 & 0.9595 & 0.8190 \\
\hline Warehouse & 0.9694 & 0.8515 & 0.9595 & 0.8190 \\
\hline Primary School & 0.9952 & 0.9816 & 0.9306 & 0.7797 \\
\hline Secondary School & 0.9983 & 0.9919 & 0.9512 & 0.8446 \\
\hline Outpatient HealthCare & 0.9926 & 0.9664 & 0.9905 & 0.9555 \\
\hline
\end{tabular}

(a) The private office space in Small Hotel is a 24-hour occupied space. It does not have unoccupied hours.

\subsubsection{Lighting}

\subsubsection{Addendum 90.1-2010ay: Daylighting Requirements}

Addendum 90.1-2010ay makes several modifications to the daylighting requirements in Chapter 9 and the daylight area definitions in Chapter 3 of Standard 90.1-2010. Due to the change in format of Chapter 9, the requirements of addendum 90.1-2010ay appear in Section 9.4.1.1 and Table 9.6.1 of Standard 90.1-2013. The new requirements are summarized as follows:

1. In Standard 90.1-2010, daylighting controls were required when the primary sidelighted area was greater than $250 \mathrm{ft}^{2}$. Addendum 90.1-2010ay modifies the area threshold to a controlled power threshold, such that, daylighting controls are required when the amount of lighting power in the sidelighted area is larger than $150 \mathrm{~W}$. Daylighting controls are also required in the secondary daylight area when the controlled power is above $300 \mathrm{~W}$ in the primary and secondary daylight area. The secondary daylight area is required to be controlled independently of the primary sidelighted area.

2. Daylighting control requirements for daylight areas under skylights and roof monitors are also changed from an area threshold to a controlled power threshold of $150 \mathrm{~W}$. This change does not have an impact on the prototype models because all the toplighted spaces are already under daylighting control. The addendum requires overlapping sidelighted and toplighted areas to be controlled as toplighted areas. This was already the case in the prototype building models.

3. The daylighting controls are required to turn off the lights completely when the illuminance target is met. 
4. The addendum modified the definition of primary and secondary sidelighted areas. Instead of a fixed $2 \mathrm{ft}$ added width in Standard 90.1-2010, the sidelighted area width is defined as one-half the head height on either side of the fenestration plus the width of the fenestration.

5. The controlled power threshold requirement eliminates the need for the effective aperture exception.

6. Daylighting documentation is required to identify the luminaires in daylight areas. This is intended to help code officials determine if the daylighting control requirements have been met.

7. The definitions of terms related to daylight area (primary sidelighted area, secondary sidelighted area, daylight area under roof monitors, and daylight area under skylights) are combined in a single portion in the definitions section.

Retail spaces and spaces where the fenestration area is less than $20 \mathrm{ft}^{2}$ are exempt from sidelighting control requirements. Dwelling units are exempt from the requirements of Chapter 9 altogether. Sidelighting controls are not applied to zones in prototype building models that are classified as retail spaces (Standalone Retail, Strip Mall) or dwelling units (High-rise Apartment, Mid-rise Apartment, Small Hotel, and Large Hotel guestrooms).

\section{Calculating the Controlled Power in Spaces with Sidelighted Areas}

The primary sidelighted area and secondary sidelighted area for each space are calculated using window dimensions in those spaces. The controlled power in the sidelighted area is calculated by multiplying the sidelighted area with the Standard 90.1-2013 lighting power density (LPD) for the space. If the controlled power exceeds the threshold, daylighting controls are applied.

In Standard 90.1-2010, daylighting controls were modeled such that lights turned off completely when the illuminance target was met. While this control feature is made mandatory by addendum 90.12010ay, it was assumed that this type of control was already in practice when the daylighting control requirements were introduced in Standard 90.1-2010. Therefore, additional savings due to the off-step control requirement are not reflected in the implementation of addendum 90.1-2010ay.

Lighting in the primary and secondary sidelighted areas needs to be controlled independently. This is implemented in EnergyPlus by using two sensors per zone when secondary sidelighted areas are required to have daylighting controls. The two sensors are located at two-thirds the depth of the primary sidelighted area and two-thirds the depth of the secondary sidelighted area from the perimeter wall. Sensors are 30 inches off the floor. The fraction of lighting controlled by each sensor will depend on the ratio of lighting power in the sidelighted area controlled by the sensor to the total lighting power in the zone. Target illuminance levels are based on the recommendations from the IES Handbook (DiLaura et al. 2011).

All prototype building zones are evaluated for sidelighting controls based on the requirements of addendum 90.1-2010ay. Table 5.20 lists the prototype buildings and zones with daylighting controls and shows the fraction of lighting power that is controlled by daylighting sensors in those zones. 
Table 5.20. Fraction of Lighting Power Controlled by Daylighting Sensors in Zones in Prototype building Models

\begin{tabular}{|c|c|c|c|}
\hline Prototype building/Zone & $\begin{array}{c}\text { Fraction of Zone } \\
\text { Controlled by } \\
\text { Primary Sidelighted } \\
\text { Area Sensor } \\
\end{array}$ & $\begin{array}{c}\text { Fraction of Zone } \\
\text { Controlled by } \\
\text { Secondary } \\
\text { Sidelighted Area } \\
\text { Sensor } \\
\end{array}$ & $\begin{array}{c}\text { Target } \\
\text { Illuminance } \\
\text { (lux) }\end{array}$ \\
\hline \multicolumn{4}{|l|}{ Small Hotel } \\
\hline Front Lounge Flr1 & 0.29 & 0.29 & 300 \\
\hline MeetingRoomFlr1 & 0.28 & 0.28 & 375 \\
\hline FrontOfficeFlr1 & 0.26 & 0.26 & 375 \\
\hline LaundryRoomFlr1 & 0.26 & 0.26 & 300 \\
\hline \multicolumn{4}{|l|}{ Large Hotel } \\
\hline LobbyFlr1 & 0.07 & 0.07 & 300 \\
\hline Café & 0.39 & 0.39 & 300 \\
\hline Dining_Flr6 & 0.20 & 0.20 & 300 \\
\hline Banquet_Flr6 & 0.20 & 0.20 & 300 \\
\hline \multicolumn{4}{|l|}{ Warehouse } \\
\hline Office & 0.29 & 0.10 & 375 \\
\hline \multicolumn{4}{|l|}{ Quick-service Restaurant } \\
\hline Dining & 0.38 & 0.38 & 300 \\
\hline \multicolumn{4}{|l|}{ Full-service Restaurant } \\
\hline Dining & 0.25 & 0.25 & 300 \\
\hline \multicolumn{4}{|l|}{ Primary School } \\
\hline Corner_Class_1_Pod_1_ZN_1_FLR_1 & 0.56 & 0.20 & 500 \\
\hline Mult_Class_1_Pod_1_ZN_1_FLR_1 & 0.28 & 0.28 & 500 \\
\hline Mult_Class_2_Pod_3_ZN_1_FLR_1 & 0.28 & 0.28 & 500 \\
\hline Computer_Class_ZN_1_FLR_1 & 0.28 & 0.28 & 500 \\
\hline Lobby_ZN__1_FLR_1 & 0.28 & 0.28 & 300 \\
\hline Offices_ZN_1_FLR_1 & 0.24 & 0.18 & 375 \\
\hline Cafeteria_ZN-_-1_FLR_1 & 0.34 & 0.16 & 300 \\
\hline Library_Media_Center_ZN_1_FLR_1 & 0.26 & 0.18 & 500 \\
\hline \multicolumn{4}{|l|}{ Secondary School } \\
\hline Corner_Class_1_Pod_1_ZN_1_FLR_1 & 0.56 & 0.20 & 500 \\
\hline Mult_Class_1_Pod_1_ZN_1_FLR_1 & 0.28 & 0.28 & 500 \\
\hline Lobby_ZN_1_FLR_1 & 0.18 & 0.18 & 300 \\
\hline Offices_ZN_1_FLR_1 & 0.36 & 0.08 & 375 \\
\hline Cafeteria_ZN_1_FLR_1 & 0.21 & 0.15 & 300 \\
\hline LIBRARY_MEDIA_CENTER_ZN_1_FLR_2 & 0.21 & 0.11 & 500 \\
\hline \multicolumn{4}{|l|}{ Outpatient Healthcare } \\
\hline Floor 3 Lounge & 0.24 & 0.24 & 300 \\
\hline Floor 3 Office & 0.19 & 0.19 & 375 \\
\hline Floor 2 Office & 0.57 & 0.43 & 375 \\
\hline Floor 2 Conference & 0.67 & 0.33 & 300 \\
\hline Floor 2 Reception & 0.23 & 0.54 & 300 \\
\hline \multicolumn{4}{|l|}{ Hospital } \\
\hline Office1_Flr_5, Office3_Flr_5 & 0.56 & 0.21 & 375 \\
\hline Lobby_Records_Flr_1 & 0.08 & 0.08 & 375 \\
\hline Office2_Mult5_Flr_5 & 0.23 & 0.23 & 375 \\
\hline Office4_Mult6_Flr_5 & 0.47 & 0.47 & 375 \\
\hline Dining_Flr_5 & 0.09 & 0.09 & 300 \\
\hline
\end{tabular}

PNNL analyzed typical daylight areas in medium office buildings (Athalye et al. 2013). Findings from the analysis are used to calculate the size of the daylight areas in perimeter zones in the Medium and 
Large Office prototype buildings. Data from the Medium Office prototype is used for the Large Office prototype. For the Small Office prototype, data from NC3 database is used. In both the baseline and advanced cases, daylighting controls are required because the sidelighted areas and the controlled lighting power exceed the respective thresholds. In Standard 90.1-2010, however, daylighting controls are not required for the secondary sidelighted area. The steps for calculating the fraction of perimeter zone that is controlled by the primary sidelighted area sensor and the secondary sidelighted area sensor are shown in Table 5.21. The major assumptions are summarized as follows:

1. For medium and large office buildings, $80 \%$ of perimeter has access to daylight and has spaces that could be daylighted, out of which $40 \%$ are open offices and $60 \%$ are enclosed offices. At least $75 \%$ of enclosed spaces are larger than $170 \mathrm{ft}^{2}$ and would require daylighting controls as per addendum 90.1-2010ay (given private office LPD). There are no secondary sidelighted areas in enclosed spaces.

2. For small office buildings, $43 \%$ of the perimeter has access to daylight and has spaces that could be daylighted, out of which $66 \%$ are enclosed offices and 33\% are open offices. All the enclosed spaces are assumed to be larger than $170 \mathrm{ft}^{2}$.

Table 5.21. Fraction of Each Perimeter Zone under Daylighting Control in Office Prototype buildings

\begin{tabular}{lccc}
\hline Assumption & Small Office & Medium Office & Large Office \\
\hline $\begin{array}{l}\text { Total primary sidelighted area as a fraction of } \\
\text { perimeter Zone Area }\end{array}$ & 0.56 & 0.56 & 0.57 \\
$\begin{array}{l}\text { Total secondary sidelighted area as a fraction of } \\
\text { perimeter zone area }\end{array}$ & 0.21 & 0.44 & 0.43 \\
$\begin{array}{l}\text { Fraction of primary sidelighted area that can be } \\
\text { daylighted }\end{array}$ & 0.43 & 0.68 & 0.68 \\
$\begin{array}{l}\text { Fraction of secondary sidelighted area that can be } \\
\text { daylighted }\end{array}$ & 0.14 & 0.32 & 0.32 \\
$\begin{array}{l}\text { Fraction of perimeter zone controlled by sensor 1 } \\
\text { (primary sidelighted area) }\end{array}$ & 0.24 & 0.38 & 0.39 \\
$\begin{array}{l}\text { Fraction of perimeter zone controlled by sensor } 2 \\
\text { (secondary sidelighted area) }\end{array}$ & 0.03 & 0.14 & 0.14 \\
\hline
\end{tabular}

\subsubsection{Addendum 90.1-2010bc: Guestroom Lighting Control}

Addendum 90.1-2007aw added automatic shut off control to the bathroom lights of guestrooms in hotels. Addendum 90.1-2010bc modifies Chapter 9 and extends the automatic shut off to other lights and switched receptacles in the guestroom, except when the lights and receptacles are controlled by captive key systems. The changes from addendum 90.1-2010bc appear in Section 9.4.1.3 of Standard 90.1-2013. The implementation of addendum 90.1-2007aw assumes 10\% reduction in lighting energy in bathroom lighting (Standard 90.1-2010, Appendix G) and that the bathroom lighting contributes 31\% of the guestroom lights.

This addendum only impacts the two hotel prototypes. Using the hourly reduction fraction for guestroom lighting in the advanced case in the 50\% AEDG for Highway Lodging (Jiang et al. 2009), a new schedule for guestroom lighting is calculated. The daily weighted reduction in the lighting power using this schedule is 38\%. For Standard 90.1-2010, only the bathroom lights are assumed to be turned off (31\% of guestroom lights) but the full reduction of $38 \%$ is applied. 
Besides lighting control, addendum 90.1-2010bc also applies to the switched receptacles in guestrooms. Again, the hourly reduction fraction for guestroom equipment in advanced models from the 50\% AEDG for Highway Lodging is used to calculate the advanced schedule. This results in a daily weighted reduction of $17 \%$ in equipment energy consumption. Both lighting and receptacle control are implemented by using different schedules for the advanced and baseline models.

\subsubsection{Addenda 90.1-2010bh, 90.1-2010cr, 90.1-2010dj, and 90.1-2010dl: Lighting Power Density (Space-by-Space Method)}

Addenda 90.1-2010bh, 90.1-2010cr, 90.1-2010dj, and 90.1-2010dl impact the space-by-space method LPD table (Table 9.6.1) in Standard 90.1-2010. These four addenda are discussed together here for clarity and to show the impact on Table 9.6.1 of Standard 90.1-2010 as a whole.

Addendum 90.1-2010bh reformats and makes extensive changes to the space-by-space LPD table, Table 9.6.1, of Standard 90.1-2010, to account for the recommended light levels published in the IES Handbook (DiLaura et al. 2011). While some LPDs have increased and some have decreased, the average reduction in LPDs is approximately 6\%. New space types are added to the table and some space types are renamed for consistency.

Addendum 90.1-2010cr changes the LPD set by addendum 90.1-2010bh for corridors in hospitals, dining areas in special facilities for the visually impaired, and sales areas. Additionally, it segregates storage rooms by size and proposes a separate, higher LPD for storage rooms smaller than $50 \mathrm{ft}^{2}$.

Addendum 90.1-2010dj adds a provision for additional lighting allowance for electrical and mechanical rooms provided the additional lighting is controlled separately from the base allowance and is not used for other purposes. This allowance ensures sufficient horizontal and vertical illuminance levels for challenging configurations of electrical and mechanical rooms. The addition of this allowance brings the allowable LPD for electrical and mechanical rooms back to the same level as in Standard 90.1-2010.

Addendum 90.1-2010dl combines the guestrooms in hotels and motels into a single category and sets the guestroom LPD to $0.91 \mathrm{~W} / \mathrm{ft}^{2}$. This is higher than the LPD for motel guestrooms and lower than the LPD for hotel guestrooms specified in Standard 90.1-2010.

All prototypes, except the three office prototype buildings, use the space-by-space LPD table. Addenda 90.1-2010bh, 90.1-2010cr, 90.1-2010dj, and 90.1-2010dl affect a number of spaces in these prototypes. The collective impact of these addenda on the prototype building models is summarized in Table 5.22. 
Table 5.22. Combined Impact of Addenda 90.1-2010bh, 90.1-2010cr, 90.1-2010dj, and 90.1-2010dl on Spaces Affected in Simulation Analysis

\begin{tabular}{|c|c|c|c|}
\hline Prototype building & Zone & $\begin{array}{c}\text { Standard 90.1-2010 } \\
\text { Space-by-Space LPD } \\
\left(\mathrm{W} / \mathrm{ft}^{2}\right)\end{array}$ & $\begin{array}{c}\text { Standard 90.1-2013 } \\
\text { Space-by-Space LPD } \\
\left(\mathrm{W} / \mathrm{ft}^{2}\right)\end{array}$ \\
\hline \multirow{5}{*}{ Hospital } & Corridor & 0.89 & 0.99 \\
\hline & Operating Room & 1.89 & 2.48 \\
\hline & Nurses' Station & 0.87 & 0.71 \\
\hline & Radiology & 1.32 & 1.51 \\
\hline & Food Preparation & 0.99 & 1.21 \\
\hline \multirow[t]{3}{*}{ Large Hotel } & Mechanical room & 0.95 & 0.42 \\
\hline & Guest rooms & 1.11 & 0.91 \\
\hline & Food Preparation & 0.99 & 1.21 \\
\hline \multirow[t]{2}{*}{ Small Hotel } & Mechanical room & 0.95 & 0.42 \\
\hline & Guest rooms & 0.75 & 0.47 \\
\hline \multirow[t]{4}{*}{ Outpatient HealthCare } & Lounge & 1.07 & 0.92 \\
\hline & Nurses' Station & 0.87 & 0.71 \\
\hline & Operating Room & 1.89 & 2.48 \\
\hline & Radiology & 1.32 & 1.51 \\
\hline \multirow[t]{2}{*}{ Quick-service Restaurant } & Food Preparation & 0.99 & 1.21 \\
\hline & Dining Area & 0.89 & 0.65 \\
\hline Full-service Restaurant & Food Preparation & 0.99 & 1.21 \\
\hline Standalone Retail & Sales Area & 1.68 & 1.44 \\
\hline Strip-mall & Sales Area & 1.68 & 1.44 \\
\hline \multirow[t]{2}{*}{ Primary School } & Mechanical room & 0.95 & 0.42 \\
\hline & Food Preparation & 0.99 & 1.21 \\
\hline \multirow[t]{3}{*}{ Secondary School } & Mechanical room & 0.95 & 0.42 \\
\hline & Food Preparation & 0.99 & 1.21 \\
\hline & Audience Seating Area & 0.79 & 0.63 \\
\hline
\end{tabular}

\subsubsection{Addendum 90.1-2010by: Lighting Controls}

Addendum 90.1-2010by represents a complete overhaul of the way interior lighting control requirements are expressed in Chapter 9. In addition to a new format, addendum 90.1-2010by adds new requirements, expands some of the existing requirements to more spaces, and adds new spaces to the list of spaces in the space-by-space method table (Table 9.6.1). Changes from addendum 90.1-2010by are discussed in further detail below:

1. Format: The new format maps control requirements to individual spaces. This is done by adding columns to the existing LPD table (Table 9.6.1) for different control requirements and by defining the individual control requirements in Section 9.4.1.1. The controls requirements are split into 9 individual requirements as follows: (a) manual control, (b) restricted to manual on, (c) restricted to partial automatic on, (d) bi-level control, (e) sidelighting controls, (f) toplighting controls, (g) automatic partial off, (h) automatic full off, and (i) scheduled shutoff.

2. Manual control (a) is required in all spaces. Requirements (b) and (c) restrict the automatic turn on of lights. For most spaces, the user is allowed to pick either (b) or (c). Automatic partial off (g) requires lighting power to be turned down by 50\% within 20 minutes of all occupants leaving the space. This is a new requirement and is not optional in some spaces. Requirements (h) and (i) have been included in 90.1-2010. The daylighting control requirements, (e) and (f), are the same as in addendum 90.12010ay, just formatted into the new table. 
3. New space types: New space types have been added, and some existing space types have been expanded to differentiate spaces. For example, stairwells have been split into stairways and stairwells, to indicate the difference between a stairway inside another space and a stairwell that is used to enter or exit a building.

4. New control requirements: A new control requirement for partial automatic turn-off has been added.

5. Shorter time for automatic turn off: Lights are now required to be turned off, either partially or fully, by automatic sensors within 20 minutes, instead of 30 minutes, of occupants leaving the space.

Of all the changes introduced by addendum 90.1-2010by, only a few changes affect energy consumption and are applicable to the prototype building models. The affected space types are as follows:

1. Partial automatic turn off: corridor (other than hospital), laboratory classrooms, lobby (other than hotels and elevator lobbies), storage $\left(>1000 \mathrm{ft}^{2}\right)$, stairwell, library stacks, and warehouse.

2. Scheduled turn off: stairwell.

3. Full automatic turn off: stairwell, healthcare spaces (exam/treatment room, imaging room, physical therapy room).

All prototypes are affected by this addendum because each prototype has at least one space type that has a new control requirement. Savings assumptions exist from previous requirements for all the lighting controls. The partial auto-off controls use the same savings assumptions as those for full off controls, except for the partial auto-off, only half the installed lighting power will be turned off.

To implement the lighting control changes, the following steps are taken:

1. Spaces with new control requirements are mapped to zones in the prototype building models.

2. Savings fractions for each control type are applied to the zones. Savings fractions from each control are accumulated to come up with a reduction fraction for each zone.

3. The accumulated reduction fraction is applied to the lighting schedule for the zone. Sometimes, one lighting schedule is applied to multiple zones with different reduction fractions. In such cases, reduction fractions from different space types and control types are weighted to determine the single reduction fraction. Table 5.23 shows the savings assumptions for the affected space types and the source of the assumptions. 
Table 5.23. Lighting Control Reduction Fraction for Space Types

\begin{tabular}{|c|c|c|c|c|}
\hline Space Types & $\begin{array}{l}\text { Unoccupied } \\
\text { Fraction } \\
\text { During } \\
\text { Occupied } \\
\text { Hours } \\
\end{array}$ & $\begin{array}{c}\text { Occupied } \\
\text { Hours } \\
\text { Savings } \\
\text { Fraction - } \\
\text { Automatic } \\
\text { Partial OFF } \\
\text { (g) }\end{array}$ & $\begin{array}{l}\text { Occupied } \\
\text { Hours } \\
\text { Savings } \\
\text { Fraction - } \\
\text { Automatic } \\
\text { Full OFF } \\
\text { (h) }\end{array}$ & Source \\
\hline \multicolumn{5}{|l|}{ General Spaces } \\
\hline Corridor - other than hospital corridors & 0.7 & 0.35 & 0.7 & Thornton et al. (2011) \\
\hline Laboratory classroom & 0.32 & 0.16 & 0.32 & Same as classroom \\
\hline $\begin{array}{l}\text { Lobby - other than in hotels and } \\
\text { elevator lobbies }\end{array}$ & 0.1 & 0.05 & 0.1 & Appendix G default \\
\hline Stairwell & 0.9 & 0.45 & 0.9 & Thornton et al. (2011) \\
\hline Storage - other (greater than $1000 \mathrm{ft}^{2}$ ) & 0.48 & 0.24 & 0.48 & Thornton et al. (2011) \\
\hline \multicolumn{5}{|l|}{ Healthcare Facility } \\
\hline in an Exam/Treatment Room & 0.22 & 0.11 & 0.22 & $\begin{array}{l}\text { Same as private office in } \\
\text { Thornton et al. (2011) }\end{array}$ \\
\hline in an Imaging Room & 0.22 & 0.11 & 0.22 & $\begin{array}{l}\text { Same as private office in } \\
\text { Thornton et al. (2011) }\end{array}$ \\
\hline in a Physical Therapy Room & 0.22 & 0.11 & 0.22 & $\begin{array}{l}\text { Same as private office in } \\
\text { Thornton et al. (2011) }\end{array}$ \\
\hline \multicolumn{5}{|l|}{ Library } \\
\hline in the Stacks & 0.3 & 0.15 & 0.3 & CASE (2011) \\
\hline \multicolumn{5}{|l|}{ Warehouse - Storage Area } \\
\hline for medium to bulky, palletized items & 0.2 & 0.1 & 0.2 & CASE (2011) \\
\hline for smaller, hand-carried items & 0.2 & 0.1 & 0.2 & CASE (2011) \\
\hline
\end{tabular}

\subsubsection{Addendum 90.1-2010co: Lighting Power Density (Building Area Method)}

Addendum 90.1-2010co makes a number of modifications to Table 9.5.1 (Building Area Method LPD) of Standard 90.1-2010 based on the recommended light levels published in the IES Lighting Handbook (DiLaura et al. 2011). While some LPDs have increased and some have decreased, the average reduction in LPDs is approximately $5 \%$.

The building area table is used by the three office prototype buildings, the library zones in the two school prototypes, office zones in the Warehouse and Hospital prototypes, and the large basement zone in the Large Hotel prototype, which is assumed to be similar to a medium office building. Table 5.24 shows the change in LPD for the affected prototype building models compared to Standard 90.1-2010. 
Table 5.24. Impact of Addendum 90.1-2010co on Prototypes

\begin{tabular}{llcc}
\hline & Zone & $\begin{array}{c}\text { Standard 90.1-2010 } \\
\text { Building Area LPD } \\
\left(\mathrm{W} / \mathrm{ft}^{2}\right)\end{array}$ & $\begin{array}{c}\text { Standard 90.1-2013 } \\
\text { Building Area LPD } \\
\left(\mathrm{W} / \mathrm{ft}^{2}\right)\end{array}$ \\
\hline Prototype building & Library & 1.18 & 1.19 \\
Primary School & Library & 1.18 & 1.19 \\
Small, Medium and Large Office & Office & 0.9 & 0.82 \\
Warehouse & Office & 0.9 & 0.82 \\
Hospital & Office & 0.9 & 0.82 \\
Large Hotel & Basement office & 0.9 & 0.82 \\
\hline
\end{tabular}




\subsection{Results}

Table 6.1 and Table 6.2 list the national EUI by building type for the 16 prototype buildings analyzed. The results are aggregated on a national basis for the 2010 and 2013 editions of Standard 90.1, respectively, based on the weighting factors discussed in Section 3.3. For each edition of Standard 90.1, the national building floor area weight used to calculate the national impact on building EUI or building ECI is presented.

Using the weighting factors by climate zone and building type, PNNL was able to estimate the relative reductions in building site energy use. Site energy refers to the energy consumed at the building site. In a corresponding fashion, PNNL was also able to calculate a reduction in terms of weighted average primary EUI, and in terms of weighted average ECI in dollars per square foot of building floor space per year. Primary energy, as used here, refers to the energy required to generate and deliver energy to the site. To estimate primary energy, all electrical EUIs were first converted to primary energy using a factor of 10,469 Btu of primary energy per kilowatt-hour (based on the 2013 estimated values reported in Table 2 of the EIA 2013 Annual Energy Outlook [AEO] ${ }^{1}$.

Table 6.1. Estimated Energy Use Intensity by Building Type - Standard 90.1-2010

\begin{tabular}{|c|c|c|c|c|c|}
\hline \multirow[b]{2}{*}{$\begin{array}{l}\text { Building } \\
\text { Type }\end{array}$} & \multirow[b]{2}{*}{ Prototype building } & \multirow{2}{*}{$\begin{array}{c}\text { Building } \\
\text { Type Floor } \\
\text { Area Weight } \\
\text { (\%) }\end{array}$} & \multicolumn{3}{|c|}{ Whole Building EUI Data for Building Population } \\
\hline & & & $\begin{array}{c}\text { Site EUI } \\
\left(\mathrm{kBtu} / \mathrm{ft}^{2}-\mathrm{yr}\right)\end{array}$ & $\begin{array}{c}\text { Source EUI } \\
\left(\mathrm{kBtu} / \mathrm{ft}^{2}-\mathrm{yr}\right)\end{array}$ & $\begin{array}{c}\text { ECI } \\
\left(\$ / \mathrm{ft}^{2}-\mathrm{yr}\right)\end{array}$ \\
\hline \multirow[t]{3}{*}{ Office } & Small Office & 5.61 & 33.0 & 100.4 & $\$ 0.99$ \\
\hline & Medium Office & 6.05 & 36.8 & 105.9 & $\$ 1.03$ \\
\hline & Large Office & 3.33 & 71.9 & 210.7 & $\$ 2.06$ \\
\hline \multirow[t]{2}{*}{ Retail } & Stand-Alone Retail & 15.25 & 53.4 & 142.9 & $\$ 1.38$ \\
\hline & Strip Mall & 5.67 & 60.4 & 164.1 & $\$ 1.58$ \\
\hline \multirow[t]{2}{*}{ Education } & Primary School & 4.99 & 59.0 & 151.1 & $\$ 1.44$ \\
\hline & Secondary School & 10.36 & 47.7 & 130.3 & $\$ 1.26$ \\
\hline \multirow[t]{2}{*}{ Healthcare } & Outpatient Health Care & 4.37 & 120.0 & 324.3 & $\$ 3.13$ \\
\hline & Hospital & 3.45 & 131.0 & 321.1 & $\$ 3.04$ \\
\hline \multirow[t]{2}{*}{ Lodging } & Small Hotel & 1.72 & 63.6 & 148.8 & $\$ 1.40$ \\
\hline & Large Hotel & 4.95 & 96.7 & 217.7 & $\$ 2.03$ \\
\hline Warehouse & Non-Refrigerated Warehouse & 16.72 & 18.2 & 43.2 & $\$ 0.41$ \\
\hline \multirow{2}{*}{$\begin{array}{l}\text { Food } \\
\text { Service }\end{array}$} & Fast-Food Restaurant & 0.59 & 591.5 & 1051.7 & $\$ 9.27$ \\
\hline & Sit-Down Restaurant & 0.66 & 383.9 & 742.7 & $\$ 6.69$ \\
\hline \multirow[t]{2}{*}{ Apartment } & Mid-Rise Apartment & 7.32 & 46.3 & 131.4 & $\$ 1.28$ \\
\hline & High-Rise Apartment & 8.97 & 50.4 & 124.9 & $\$ 1.19$ \\
\hline National & & 100 & 58.5 & 148.9 & $\$ 1.42$ \\
\hline
\end{tabular}

${ }^{1}$ Available at http://www.eia.gov/oiaf/aeo/tablebrowser/\#release $=$ AEO2013\&subject $=0$ $\underline{\text { AEO2013\&table=2-AEO2013\&region=1-0\&cases=ref2013-d102312a) }}$ 
Table 6.2. Estimated Energy Use Intensity by Building Type - Standard 90.1-2013

\begin{tabular}{|c|c|c|c|c|c|}
\hline \multirow[b]{2}{*}{$\begin{array}{l}\text { Building } \\
\text { Type }\end{array}$} & \multirow[b]{2}{*}{ Prototype building } & \multirow{2}{*}{$\begin{array}{c}\text { Building } \\
\text { Type Floor } \\
\text { Area Weight } \\
(\%)\end{array}$} & \multicolumn{3}{|c|}{ Whole Building EUI Data for Building Population } \\
\hline & & & $\begin{array}{c}\text { Site EUI } \\
\left(\mathrm{kBtu} / \mathrm{ft}^{2}-\mathrm{yr}\right)\end{array}$ & $\begin{array}{l}\text { Source EUI } \\
\left(\mathrm{kBtu} / \mathrm{ft}^{2}-\mathrm{yr}\right)\end{array}$ & $\begin{array}{c}\text { ECI } \\
\left(\$ / \mathrm{ft}^{2}-\mathrm{yr}\right)\end{array}$ \\
\hline \multirow[t]{3}{*}{ Office } & Small Office & 5.61 & 29.4 & 89.3 & $\$ 0.88$ \\
\hline & Medium Office & 6.05 & 34.1 & 97.9 & $\$ 0.95$ \\
\hline & Large Office & 3.33 & 70.8 & 205.8 & $\$ 2.01$ \\
\hline \multirow[t]{2}{*}{ Retail } & Stand-Alone Retail & 15.25 & 45.9 & 124.6 & $\$ 1.20$ \\
\hline & Strip Mall & 5.67 & 55.1 & 147.3 & $\$ 1.42$ \\
\hline \multirow[t]{2}{*}{ Education } & Primary School & 4.99 & 54.2 & 134.4 & $\$ 1.28$ \\
\hline & Secondary School & 10.36 & 41.7 & 111.9 & $\$ 1.08$ \\
\hline \multirow[t]{2}{*}{ Healthcare } & Outpatient Health Care & 4.37 & 115.8 & 311.8 & $\$ 3.00$ \\
\hline & Hospital & 3.45 & 123.7 & 300.7 & $\$ 2.85$ \\
\hline \multirow[t]{2}{*}{ Lodging } & Small Hotel & 1.72 & 60.0 & 137.6 & $\$ 1.29$ \\
\hline & Large Hotel & 4.95 & 89.0 & 195.4 & $\$ 1.81$ \\
\hline Warehouse & $\begin{array}{l}\text { Non-Refrigerated } \\
\text { Warehouse } \\
\end{array}$ & 16.72 & 17.1 & 40.6 & $\$ 0.38$ \\
\hline \multirow{2}{*}{$\begin{array}{l}\text { Food } \\
\text { Service }\end{array}$} & Fast-Food Restaurant & 0.59 & 576.4 & 1001.9 & $\$ 8.78$ \\
\hline & Sit-Down Restaurant & 0.66 & 372.5 & 713.5 & $\$ 6.41$ \\
\hline \multirow[t]{2}{*}{ Apartment } & Mid-Rise Apartment & 7.32 & 43.9 & 124.8 & $\$ 1.21$ \\
\hline & High-Rise Apartment & 8.97 & 46.9 & 114.4 & $\$ 1.08$ \\
\hline National & & 100 & 54.1 & 136.2 & $\$ 1.30$ \\
\hline
\end{tabular}

The conversion factor of 10,469 was calculated from AEO Table 2 by summing the commercial electricity value of 4.47 quads with the electricity losses value of 9.24 quads and then dividing that sum by the commercial value $((4.47+9.24) / 4.47=3.07)$. This yields a ratio of 3.07 for converting how much primary (source) energy is required per unit of site required electricity. This ratio of 3.07 is then multiplied by 3,412 Btu/kWh, producing a value of 10,469 Btu of primary energy per kilowatt-hour of site energy. ${ }^{1}$ Natural gas EUIs in the prototype buildings were converted to primary energy using a factor of 1.093 Btu of primary energy per Btu of site natural gas use (based on the 2014 national energy use estimated shown in Table 2 of the AEO2013). This natural gas source energy conversion factor was calculated by dividing the natural gas subtotal of 25.87 quads (sum of all natural gas usage, including usage for natural gas field production, leases, plant energy, and pipeline [compression] supply) by the delivered natural gas total of 23.67 quads (sum of four primary energy sectors (residential, commercial, industrial, and transportation).

To estimate the reduction in energy cost index, PNNL relied on national average commercial building energy prices of $\$ 0.1029 / \mathrm{kWh}$ of electricity and $\$ 8.17$ per 1000 cubic feet (\$0.796/therm) of natural gas, based on EIA statistics for 2013 (the last complete year of data available) in Table 2, "U.S. Energy Prices,” of the February 2014 Short Term Energy Outlook for commercial sector natural gas and electricity $^{2}$. DOE recognizes that actual energy costs will vary somewhat by building type within a region, and will in fact vary more across regions. Nevertheless, DOE believes that the use of simple

\footnotetext{
${ }^{1}$ The final conversion value of 10,469 is calculated using the full seven digit values available in Table 2 of AEO2013. Other values shown in the text are rounded.

${ }^{2}$ EIA Short Term Energy Outlook available at http://www.eia.gov/forecasts/steo/report/.
} 
national average figures illustrates whether there will be energy cost savings sufficient for the purposes of the DOE determination. The resulting EUI statistics for site and primary energy are listed in Table 6.1 and Table 6.2 for Standard 90.1-2010 and Standard 90.1-2013, respectively. In terms of energy expenditures per square foot per year, ECI statistics are provided as well in these tables. Table 6.3 presents the estimated percent energy savings (based on change in EUIs) between the 2010 and 2013 editions of Standard 90.1.

Considering those differences that can be reasonably quantified, the 2013 edition will increase the energy efficiency of commercial buildings. On a national basis, the preliminary quantitative analysis estimated a floor-space-weighted national average reduction in new building energy consumption of 8.5\% for source energy and $7.6 \%$ when considering site energy. An $8.7 \%$ savings in energy cost, based on national average commercial energy costs for electricity and natural gas, was also estimated. National savings results by building type are shown in Figure 6.1.

Table 6.3. Estimated Percent Energy Savings between 2010 and 2013 Editions of Standard 90.1 - by Building Type

\begin{tabular}{|c|c|c|c|c|c|}
\hline \multirow[b]{2}{*}{ Building Type } & \multirow[b]{2}{*}{ Prototype building } & \multirow{2}{*}{$\begin{array}{l}\text { Building Type } \\
\text { Floor Area } \\
\text { Weight } \\
(\%)\end{array}$} & \multicolumn{3}{|c|}{$\begin{array}{c}\text { Percent Savings in Whole Building } \\
\text { Energy Use Intensity } \\
(\%) \\
\end{array}$} \\
\hline & & & Site EUI & Source EUI & ECI \\
\hline \multirow[t]{3}{*}{ Office } & Small Office & 5.61 & 11.0 & 11.0 & 11.0 \\
\hline & Medium Office & 6.05 & 7.4 & 7.5 & 7.5 \\
\hline & Large Office & 3.33 & 1.4 & 2.4 & 2.5 \\
\hline \multirow[t]{2}{*}{ Retail } & Stand-Alone Retail & 15.25 & 13.9 & 12.8 & 12.6 \\
\hline & Strip Mall & 5.67 & 8.8 & 10.2 & 10.5 \\
\hline \multirow[t]{2}{*}{ Education } & Primary School & 4.99 & 8.1 & 11.0 & 11.5 \\
\hline & Secondary School & 10.36 & 12.6 & 14.1 & 14.4 \\
\hline \multirow[t]{2}{*}{ Healthcare } & Outpatient Health Care & 4.37 & 3.6 & 3.9 & 3.9 \\
\hline & Hospital & 3.45 & 5.6 & 6.4 & 6.5 \\
\hline \multirow[t]{2}{*}{ Lodging } & Small Hotel & 1.72 & 5.7 & 7.5 & 7.9 \\
\hline & Large Hotel & 4.95 & 8.0 & 10.2 & 10.7 \\
\hline Warehouse & Non-Refrigerated Warehouse & 16.72 & 6.0 & 6.1 & 6.1 \\
\hline \multirow[t]{2}{*}{ Food Service } & Fast Food Restaurant & 0.59 & 2.6 & 4.7 & 5.3 \\
\hline & Sit-Down Restaurant & 0.66 & 3.0 & 3.9 & 4.2 \\
\hline \multirow[t]{2}{*}{ Apartment } & Mid-Rise Apartment & 7.32 & 5.4 & 5.1 & 5.0 \\
\hline & High-Rise Apartment & 8.97 & 6.9 & 8.4 & 8.7 \\
\hline National & & 100 & 7.6 & 8.5 & 8.7 \\
\hline
\end{tabular}




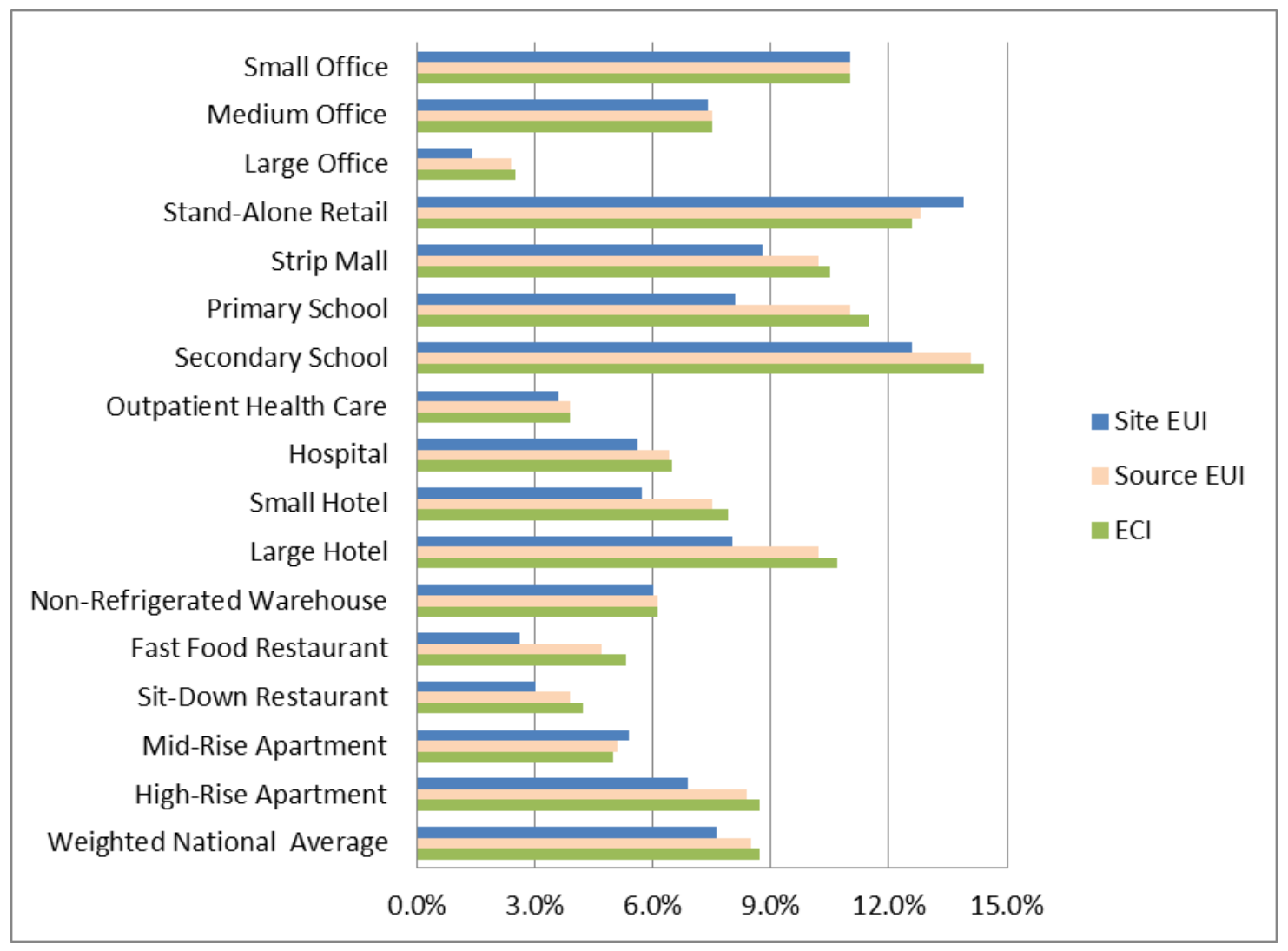

Figure 6.1. Percentage Savings by Building Type from 90.1-2010 to 90.1-2013 


\subsection{References}

10 CFR 431. Chapter 10, Code of Federal Regulations, Part 431. Energy Efficiency Program for Certain Commercial and Industrial Equipment. U.S. Department of Energy, Washington, D.C. Available at http://www.gpo.gov/fdsys/pkg/CFR-2006-title10-vol3/pdf/CFR-2006-title10-vol3-part431.pdf.

42 U.S.C. 6833. Chapter 42, U.S. Code, Section 6833. Available at http://www.gpo.gov/fdsys/pkg/USCODE-2011-title42/pdf/USCODE-2011-title42-chap81-subchapII.pdf.

AHRI. 2007. AHRI 340/360-2007 with Addenda 1 and 2. Performance Rating of Commercial and Industrial Unitary Air-Conditioning and Heat Pump Equipment. Air Conditioning, Heating and Refrigeration Institute, Arlington, Virginia.

AHRI. 2008. AHRI 210/240-200 with Addendum 1 and 2. Unitary Air Conditioning and Air-Source Heat Pump Equipment. Air Conditioning, Heating and Refrigeration Institute, Arlington, Virginia.

AHRI. 2010. AHRI 1230-2010 with Addendum 1. Performance Rating of Variable Refrigerant Flow (VRF) Multi-split Air-Conditioning and Heat Pump Equipment. Air Conditioning, Heating and Refrigeration Institute, Arlington, Virginia.

AHRI. 2011. AHRI 550/590-2011 (I-P) with Addendum 1 and AHRI 551/591 (SI). Performance Rating of Water-Chilling and Heat-Pump Water-Heating Packages Using the Vapor Compression Cycle. Air Conditioning, Heating and Refrigeration Institute, Arlington, Virginia.

AMCA. 2012. AMCA 500 ANSI/AMCA 500-D-12. Laboratory Methods of Testing Dampers for Rating. Air Movement and Control Association International, Arlington Heights, Illinois

ANSI. 2011. ANSI Z21.10.3-2011. Gas Water Heater, Volume 3, Storage, with Input Ratings above 75,000 Btu/h, Circulating and Instantaneous Water Heaters. American National Standards Institute, New York, New York.

ANSI. 2012. ANSI Z21.47-2012. Gas-Fired Central Furnaces. American National Standards Institute, New York, New York.

ASHRAE. 2007. ANSI/ASHRAE Standard 62.1-2007. Ventilation for Acceptable Indoor Air Quality. American Society of Heating, Refrigerating, and Air-Conditioning Engineers, Atlanta, Georgia.

ASHRAE. 2010a. ANSI/ASHRAE Standard 55-2010. Thermal Environmental Conditions for Human Occupancy. American Society of Heating, Refrigerating, and Air-Conditioning Engineers, Atlanta, Georgia.

ASHRAE. 2010b. ANSI/ASHRAE/IES Standard 90.1-2010. Energy Standard for Buildings Except Low-Rise Residential Buildings. American Society of Heating, Refrigerating, and Air-Conditioning Engineers, Atlanta, Georgia. 
ASHRAE. 2011. ANSI/ASHRAE Standard 140-2011. Standard Method of Test for the Evaluation of Building Energy Analysis Computer Programs. American Society of Heating, Refrigerating, and AirConditioning Engineers, Atlanta, Georgia.

ASHRAE. 2012. 2012 Supplement to ANSI/ASHRAE/IES Standard 90.1-2010. Energy Standard for Buildings Except Low-Rise Residential Buildings. American Society of Heating, Refrigerating, and AirConditioning Engineers, Atlanta, Georgia. Available for free download at https://www.ashrae.org/File\%20Library/docLib/StdsAddenda/90_1_2010_2012AddendaSupplement_Pub lished.pdf.

ASHRAE. 2013a. 2013 Supplement to ANSI/ASHRAE/IES Standard 90.1-2010. Energy Standard for Buildings Except Low-Rise Residential Buildings. American Society of Heating, Refrigerating, and AirConditioning Engineers, Atlanta, Georgia. Available for free download at https://www.ashrae.org/File\%20Library/docLib/StdsAddenda/90_1_2010_2013Addenda.pdf.

ASHRAE. 2013b. ANSI/ASHRAE/IES Standard 90.1-2013. Energy Standard for Buildings Except Low-Rise Residential Buildings. American Society of Heating, Refrigerating, and Air-Conditioning Engineers, Atlanta, Georgia. Read-only version available at http://openpub.realread.com/rrserver/browser?title=/ASHRAE_1/ashrae_90_1_2013_1024.

ASME/CSA. 2010. ASME A17.1-2010/CSA B44-10. Safety Code for Elevators and Escalators. American Society of Mechanical Engineers, New York, New York.

Athalye RA, YL Xie, B Liu, and MI Rosenberg. 2013. Analysis of Daylighting Requirements within ASHRAE Standard 90.1. PNNL-22698, Pacific Northwest National Laboratory, Richland, Washington. Available at http://www.pnnl.gov/main/publications/external/technical_reports/PNNL-22698.pdf.

Briggs RL, RG Lucas, and ZT Taylor. 2003. "Climate Classification for Building Energy Codes and Standards: Part 1—Development Process,” ASHRAE Transactions (1):4610-4611.

CASE. 2011. Automated Lighting Controls and Switching Requirements in Warehouses and Libraries. Codes and Standards Enhancement Initiative (CASE): 2013 California Building Energy Efficiency Standards, Sacramento, California.

CEC. 2008. California Code of Regulations Title 20, Public Utilities and Energy Division 2. State Energy Resources Conservation and Development Commission, Sacramento, California. Available at http://www.energy.ca.gov/2008publications/CEC-140-2008-001/CEC-140-2008-001-REV1.PDF.

CRRC. 2012. CRRC-1 Standard. Cool Roof Rating Council, Oakland, California.

DiLaura DL, KW Houser, RG Mistrick, and GR Steffy. 2011. The Lighting Handbook, $10^{\text {th }}$ Edition. Illuminating Engineering Society, New York, New York.

DOE. 2013. Energy Plus Energy Simulation Software, Version 8.0. U.S. Department of Energy, Washington, D.C. Available at http://apps1.eere.energy.gov/buildings/EnergyPlus/.

ECPA. Energy Conservation and Production Act of 1976. Public Law 94-385. Available at http://www.gpo.gov/fdsys/pkg/STATUTE-90/pdf/STATUTE-90-Pg1125.pdf. 
EIA. 2003. Commercial Buildings Energy Consumption Survey 2003. Energy Information Administration of U.S. Department of Energy, Washington, D.C. Available at http://www.eia.doe.gov/emeu/cbecs/contents.html.

Gowri K, MA Halverson, and EE Richman. 2007. Analysis of Energy Saving Impacts of ASHRAE 90.12004 for New York. PNNL-16770, Pacific Northwest National Laboratory, Richland, Washington. Available at http://www.pnl.gov/main/publications/external/technical_reports/PNNL-16770.pdf.

Halverson M, M Rosenberg, R Hart, E Richman, R Athalye, and D. Winiarski. 2014. ANSI/ASHRAE/IES Standard 90.1-2013 Preliminary Qualitative Determination. PNNL-23198, Pacific Northwest National Laboratory, Richland, Washington.

Jarnagin RE and GK Bandyopadhyay. 2010. Weighting Factors for the Commercial Prototype buildings Used in the Development of ANSI/ASHRAE/IENSA Standard 90.1-2010. PNNL-19116, Pacific

Northwest National Laboratory, Richland, Washington. Available at http://www.pnl.gov/main/publications/external/technical_reports/PNNL-19116.pdf.

Jiang W, K Gowri, MD Lane, BA Thornton, MI Rosenberg, and B Liu. 2009. Technical Support Document: 50\% Energy Savings Design Technology Packages for Highway Lodging Buildings. Pacific Northwest National Laboratory, Richland, Washington.

Navigant. 2009. Energy Savings Potential and R\&D Opportunities for Commercial Refrigeration - Final Report. Navigant Consulting, Inc, Washington, District of Columbia. Available at http://apps1.eere.energy.gov/buildings/publications/pdfs/corporate/commercial refrig report 10-09.pdf.

NEMA. 2006. ANSI/NEMA MG 1-2006. Motors and Generators. National Electrical Manufacturers Association, Rosslyn, Virginia.

NFPA. 2011. NFPA 70 Article 708-2011. Critical Operations Power Systems (COPS). National Fire Protection Association, Quincy, Massachusetts.

NFPA. 2012. NFPA 96-12. Ventilation Control and Fire Protection of Commercial Cooking Operations. National Fire Protection Association, Quincy, Massachusetts.

NFRC. 2010. NFRC 301-2010. Test Method for Emittance of Specular Surfaces Using Spectrometric Measurements. National Fenestration Rating Council, Greenbelt, Maryland.

PNNL. 2014. Enhancements to ASHRAE Standard 90.1 Prototype Building Models. Pacific Northwest National Laboratory, Richland, Washington. Available at https://www.energycodes.gov/development/commercial/90.1 models.

Richman EE, E Rauch, J Knappek, J Phillips, K Petty, and P Lopez-Rangel. 2008. “National Commercial Construction Characteristics and Compliance with Building Energy Codes: 1999-2007.” 2008 ACEEE Summer Study on Energy Efficiency in Buildings, ACEEE Publications, Washington D.C.

Thornton, B. A., Wang, W., Cho, H., Xie, Y., Mendon, V. V., Richman, E. E., Zhang, J., Athalye, R. A., Rosenberg, M. I., and Liu, B.. 2011. Achieving 30\% Goal: Energy and Cost Saving Analysis of 
ASHRAE/IES Standard 90.1-2010. Pacific Northwest National Laboratory, Richland, Washington. Available at http://www.energycodes.gov/publications/research/documents/codes/PNNL-20405.pdf.

Treasury and General Government Appropriations Act for Fiscal Year 2001. Public Law 106-554. Available at http://www.gpo.gov/fdsys/pkg/PLAW-106publ554/pdf/PLAW-106publ554.pdf.

Wasner L. and Lundgreen J. 2007. Steam Humidification: Reducing Energy Use, Airstream Heat Gain, and Condensate Production. HPAC Engineering. April 2007. 
Appendix A. Addenda Processed for ANSI/ASHRAE/IES Standard 90.1-2013 
Table A.1.Complete List of Addenda Processed for ASHRAE Standard 90.1-2013

\begin{tabular}{|c|c|c|c|c|c|c|}
\hline Addendum & $\begin{array}{c}\text { Section(s) } \\
\text { Affected }\end{array}$ & Description of Changes & $\begin{array}{l}\text { ASHRAE } \\
\text { Standards } \\
\text { Committee } \\
\text { Approval }\end{array}$ & $\begin{array}{l}\text { ASHRAE } \\
\text { BOD }\end{array}$ & $\begin{array}{l}\text { IES BOD } \\
\text { Approval }\end{array}$ & $\begin{array}{c}\text { ANSI } \\
\text { Approval }\end{array}$ \\
\hline $\begin{array}{l}\text { bb } \\
\text { (formerly } \\
\text { addendum } \\
\text { bb to } 90.1- \\
\text { 2007) }\end{array}$ & $\begin{array}{l}\text { 5.Building } \\
\text { Envelope, } \\
\text { Appendix A }\end{array}$ & $\begin{array}{l}\text { This addendum modifies the building envelope requirements for opaque } \\
\text { assemblies and fenestration in Tables 5.5-1 through 5.5-8 and the } \\
\text { associated text in Section 5.5.4.5. It also updates the National } \\
\text { Fenestration Rating Council (NFRC) } 301 \text { reference and modifies two } \\
\text { metal building roof assemblies in Table A.2.3. }\end{array}$ & $3 / 23 / 2012$ & $4 / 4 / 2012$ & $3 / 23 / 2012$ & $5 / 11 / 2012$ \\
\hline $\begin{array}{l}\text { (formerly } \\
\text { addendum } \\
\text { bz to } 90.1- \\
\text { 2007) }\end{array}$ & $\begin{array}{l}\text { 6. Heating, } \\
\text { Ventilating, } \\
\text { and Air- } \\
\text { Conditioning }\end{array}$ & $\begin{array}{l}\text { This addendum adds a Section } 8.4 .2 \text { which specifies requirements for } \\
\text { installation of basic electrical metering of major end uses (total } \\
\text { electrical energy, HVAC systems, interior lighting, exterior lighting and } \\
\text { receptacle circuits) to provide basic reporting of energy consumption } \\
\text { data to building occupants. }\end{array}$ & $1 / 21 / 2012$ & $1 / 23 / 2012$ & $1 / 18 / 2012$ & $1 / 26 / 2012$ \\
\hline $\begin{array}{l}\text { cg } \\
\text { (formerly } \\
\text { addendum } \\
\text { cg to } 90.1- \\
\text { 2007) }\end{array}$ & $\begin{array}{l}\text { 11.Energy } \\
\text { Cost Budget } \\
\text { and Appendix } \\
\text { G }\end{array}$ & $\begin{array}{l}\text { This addendum modifies the simulation requirements for modeling } \\
\text { mandatory automatic daylighting controls as well as automatic lighting } \\
\text { controls. It also modifies the simulation requirements for automatic } \\
\text { lighting controls in the proposed design, beyond the minimum } \\
\text { mandatory requirements. Table G3.2, which provided power } \\
\text { adjustment percentages for automatic lighting controls, has been deleted } \\
\text { and savings through automatic control devices are now required to be } \\
\text { modeled in building simulation through schedule adjustments for the } \\
\text { proposed design. }\end{array}$ & $1 / 21 / 2012$ & $1 / 23 / 2012$ & $1 / 18 / 2012$ & $1 / 26 / 2012$ \\
\hline $\begin{array}{l}\text { ci } \\
\text { (formerly } \\
\text { addendum } \\
\text { ci to } 90.1- \\
\text { 2007) }\end{array}$ & $\begin{array}{l}\text { 3.Definitions, } \\
\text { 11.Energy } \\
\text { Cost Budget } \\
\text { and Appendix } \\
\text { G }\end{array}$ & $\begin{array}{l}\text { This addendum modifies requirements for the cooling tower in Chapter } \\
\text { 11, from two-speed to variable speed. A formula has been specified to } \\
\text { calculate the condenser water design supply temperature. Similar } \\
\text { revisions have been made to Appendix G for the cooling tower } \\
\text { requirements. Definitions for cooling design wet-bulb temperature and } \\
\text { heating design wet-bulb temperature have been added to Chapter } 3 \text {. }\end{array}$ & $1 / 21 / 2012$ & $1 / 23 / 2012$ & $1 / 18 / 2012$ & $1 / 26 / 2012$ \\
\hline $\begin{array}{l}\text { cj } \\
\text { (formerly } \\
\text { addendum } \\
\text { cj to 90.1- } \\
\text { 2007) }\end{array}$ & Appendix G & Creates modeling rules for computer rooms in Appendix G. & $6 / 26 / 2012$ & 41086 & $6 / 28 / 2013$ & $7 / 24 / 2013$ \\
\hline $\begin{array}{l}\text { cm } \\
\text { (formerly } \\
\text { addendum } \\
\text { cm to 90.1- } \\
\text { 2007) }\end{array}$ & $\begin{array}{l}\text { 5. Building } \\
\text { Envelope }\end{array}$ & $\begin{array}{l}\text { The proposed text clarifies how to interpret the use of dynamic glazing } \\
\text { products given the requirements in addendum bb (envelope } \\
\text { requirements). }\end{array}$ & $7 / 20 / 2010$ & $7 / 23 / 2010$ & $7 / 24 / 2010$ & $7 / 26 / 2010$ \\
\hline
\end{tabular}




\begin{tabular}{|c|c|c|c|c|c|c|}
\hline Addendum & $\begin{array}{c}\text { Section(s) } \\
\text { Affected }\end{array}$ & Description of Changes & $\begin{array}{l}\text { ASHRAE } \\
\text { Standards } \\
\text { Committee } \\
\text { Approval }\end{array}$ & $\begin{array}{l}\text { ASHRAE } \\
\text { BOD }\end{array}$ & $\begin{array}{l}\text { IES BOD } \\
\text { Approval }\end{array}$ & $\begin{array}{c}\text { ANSI } \\
\text { Approval }\end{array}$ \\
\hline $\begin{array}{l}\text { dm } \\
\text { (previously } \\
\text { from 2007) }\end{array}$ & $\begin{array}{l}\text { 5. Building } \\
\text { Envelope }\end{array}$ & $\begin{array}{l}\text { This addendum modifies Section 5.4.3.4 for vestibules. It adds a size } \\
\text { limit for large buildings, exemptions for semiheated spaces and elevator } \\
\text { lobbies in parking garages. }\end{array}$ & $1 / 26 / 2013$ & $1 / 29 / 2013$ & $2 / 11 / 2013$ & $2 / 12 / 2013$ \\
\hline $\begin{array}{l}\text { ds } \\
\text { (formerly } \\
\text { addendum } \\
\text { ds to } 90.1- \\
\text { 2007) }\end{array}$ & $\begin{array}{l}\text { 5.Building } \\
\text { Envelope }\end{array}$ & $\begin{array}{l}\text { This addendum corrects the definitions of primary sidelighted area, } \\
\text { secondary sidelighted area, and sidelighting effective area to use the } \\
\text { term "vertical fenestration" instead of "window" to clarify that glazed } \\
\text { doors and other fenestration products are included as well as windows. } \\
\text { Additionally, the definition of daylight area under rooftop monitors is } \\
\text { corrected to include the spread of light beyond the width of the rooftop } \\
\text { monitor glazing. }\end{array}$ & $1 / 21 / 2012$ & $1 / 23 / 2012$ & $1 / 18 / 2012$ & $1 / 26 / 2012$ \\
\hline a & $\begin{array}{l}\text { 10.Other } \\
\text { Equipment } \\
\text { and } \\
\text { 12.Normative } \\
\text { References }\end{array}$ & $\begin{array}{l}\text { This addendum specifies that nominal efficiencies for motors are } \\
\text { required to be established in accordance with DOE } 10 \text { CFR } 431 \text { instead } \\
\text { of National Electrical Manufacturers Association (NEMA) Standards. } \\
\text { It modifies the footnotes to Tables } 10.8 \mathrm{~A}, 10.8 \mathrm{~B}, 10.8 \mathrm{C} \text {. The } \\
\text { corresponding reference for } 10 \text { CFR } 431 \text { has also been added. }\end{array}$ & $1 / 21 / 2012$ & $1 / 23 / 2012$ & $1 / 18 / 2012$ & $1 / 26 / 2012$ \\
\hline b & $\begin{array}{l}\text { 10.Other } \\
\text { Equipment } \\
\text { and } \\
\text { 12.Normative } \\
\text { References }\end{array}$ & $\begin{array}{l}\text { This addendum requires escalators and moving walkways to } \\
\text { automatically slow when not conveying passengers. The corresponding } \\
\text { reference to American Society of Mechanical Engineers (ASME) } \\
\text { A17.1/ Canadian Standards Association (CSA) B44 has also been added } \\
\text { to the Normative References. }\end{array}$ & $6 / 25 / 2011$ & 6/29/2011 & 6/30/2011 & 6/30/2011 \\
\hline c & Appendix G & $\begin{array}{l}\text { This addendum adds requirements for laboratory exhaust fans to Section } \\
\text { G3.1.1, Baseline HVAC System Type and Definition. Lab exhaust fans } \\
\text { are required to be modeled as constant horsepower, reflecting constant } \\
\text { volume stack discharge with outside air bypass. }\end{array}$ & $6 / 25 / 2011$ & $6 / 29 / 2011$ & 6/30/2011 & $6 / 30 / 2011$ \\
\hline e & Appendix G & $\begin{array}{l}\text { This addendum updates language in Section G3.1, part } 5 \text { 'Building } \\
\text { Envelope', to require that existing buildings use the same envelope } \\
\text { baseline as new buildings with the exception of fenestration area. }\end{array}$ & 6/27/2012 & 6/27/2012 & 6/18/2012 & 7/26/2012 \\
\hline $\mathrm{f}$ & Appendix G & $\begin{array}{l}\text { This addendum modifies Section G.3.1, Building Envelope. It specifies } \\
\text { the vertical fenestration area for calculating baseline building } \\
\text { performance for new buildings and additions. }\end{array}$ & 6/26/2013 & 6/26/2013 & 6/28/2013 & $7 / 24 / 2013$ \\
\hline
\end{tabular}




\begin{tabular}{|c|c|c|c|c|c|c|}
\hline Addendum & $\begin{array}{c}\text { Section(s) } \\
\text { Affected }\end{array}$ & Description of Changes & $\begin{array}{l}\text { ASHRAE } \\
\text { Standards } \\
\text { Committee } \\
\text { Approval }\end{array}$ & $\begin{array}{c}\text { ASHRAE } \\
\text { BOD }\end{array}$ & $\begin{array}{l}\text { IES BOD } \\
\text { Approval }\end{array}$ & $\begin{array}{c}\text { ANSI } \\
\text { Approval }\end{array}$ \\
\hline g & $\begin{array}{l}\text { 6. Heating, } \\
\text { Ventilating, } \\
\text { and Air- } \\
\text { Conditioning } \\
\text { and } \\
\text { 12.Normative } \\
\text { References }\end{array}$ & $\begin{array}{l}\text { This addendum adds efficiency requirements for commercial } \\
\text { refrigerators, freezers and refrigeration equipment. Table 6.8.1L and } \\
\text { Table 6.8.1M (now Tables 6.8.1-12 and 6.8.1-13 in Standard 90.1-2013) } \\
\text { have been added which specify the energy use limits for refrigerators } \\
\text { and freezers. The corresponding references to federal standards have } \\
\text { also been added in Chapter } 12 .\end{array}$ & $6 / 25 / 2011$ & $6 / 29 / 2011$ & $6 / 30 / 2011$ & $6 / 30 / 2011$ \\
\hline h & $\begin{array}{l}\text { 6. Heating, } \\
\text { Ventilating, } \\
\text { and Air- } \\
\text { Conditioning. }\end{array}$ & $\begin{array}{l}\text { This addendum modifies the minimum efficiency standards for water to } \\
\text { air heat pumps (water loop, ground water and ground loop). The } \\
\text { proposed cooling energy efficiency ratios (EERs) and heating } \\
\text { coefficients of performance (COPs) are more stringent than the present } \\
\text { values. This addendum also removes the small duct high velocity } \\
\text { product class from Table 6.8.1B (now Table 6.8.1-2 in Standard 90.1- } \\
\text { 2013). }\end{array}$ & $6 / 25 / 2011$ & $6 / 29 / 2011$ & $6 / 30 / 2011$ & $6 / 30 / 2011$ \\
\hline $\mathrm{i}$ & $\begin{array}{l}\text { 6. Heating, } \\
\text { Ventilating, } \\
\text { and Air- } \\
\text { Conditioning. }\end{array}$ & $\begin{array}{l}\text { This addendum increases the minimum efficiency standards for single } \\
\text { package vertical air conditioners (SPVAC) and single package vertical } \\
\text { heat pumps (SPVHP). It also creates a new product class for SPVAC } \\
\text { and SPVHP used in space constrained applications. This new product } \\
\text { class only applies to non-weatherized products with cooling capacities } \\
<36,000 \mathrm{Btu} / \mathrm{h} \text { and intended to replace an existing AC. }\end{array}$ & $1 / 26 / 2013$ & $1 / 29 / 2013$ & 2/11/2013 & $2 / 12 / 2013$ \\
\hline $\mathrm{j}$ & $\begin{array}{l}\text { 6. Heating, } \\
\text { Ventilating, } \\
\text { and Air- } \\
\text { Conditioning. }\end{array}$ & $\begin{array}{l}\text { Modifies the minimum efficiency requirements of evaporatively cooled } \\
\text { units, of size category 240,000 Btu/h to 760,000 Btu/h and heating type- } \\
\text { other, in Table 6.8.1A (now Table 6.8.1-1 in Standard 90.1-2013). The } \\
\text { value is reduced to account for increased pressure drop in such system } \\
\text { types. The product class, small duct high velocity, has been eliminated. }\end{array}$ & $6 / 25 / 2011$ & $6 / 29 / 2011$ & $6 / 30 / 2011$ & $6 / 30 / 2011$ \\
\hline $\mathrm{k}$ & $\begin{array}{l}\text { 8. Power and } \\
12 . \\
\text { Normative } \\
\text { References }\end{array}$ & $\begin{array}{l}\text { This addendum modifies notes to Table } 8.1 \text { and specifies that nominal } \\
\text { efficiencies would be established in accordance with the } 10 \text { CFR } 431 \\
\text { test procedure for low- voltage dry-type transformers. The } \\
\text { corresponding references have also been added in Chapter } 12 \text {. }\end{array}$ & $6 / 25 / 2011$ & 6/29/2011 & 6/30/2011 & $6 / 30 / 2011$ \\
\hline 1 & $\begin{array}{l}\text { 6. Heating, } \\
\text { Ventilating, } \\
\text { and Air- } \\
\text { Conditioning. }\end{array}$ & $\begin{array}{l}\text { This addendum fixes the error with } 90.1-2010 \text { fan power limitations, } \\
\text { which required the user to perform calculations for fan brake } \\
\text { horsepower (bhp) even if the simplified nameplate hp option was being } \\
\text { used. }\end{array}$ & $6 / 27 / 2012$ & $6 / 27 / 2012$ & $6 / 18 / 2012$ & $6 / 28 / 2012$ \\
\hline
\end{tabular}




\begin{tabular}{|c|c|c|c|c|c|c|}
\hline Addendum & $\begin{array}{l}\text { Section(s) } \\
\text { Affected }\end{array}$ & Description of Changes & $\begin{array}{l}\text { ASHRAE } \\
\text { Standards } \\
\text { Committee } \\
\text { Approval }\end{array}$ & $\begin{array}{c}\text { ASHRAE } \\
\text { BOD }\end{array}$ & $\begin{array}{l}\text { IES BOD } \\
\text { Approval }\end{array}$ & $\begin{array}{c}\text { ANSI } \\
\text { Approval }\end{array}$ \\
\hline $\mathrm{m}$ & 9.Lighting & $\begin{array}{l}\text { This addendum adds some control requirements for lighting alterations, } \\
\text { for interior and exterior applications. It adds a section for submittals } \\
\text { and includes loading docks as a tradable surface. It modifies the } \\
\text { provisions for additional interior lighting power, which would now be } \\
\text { calculated on the basis of controlled wattage. }\end{array}$ & $6 / 27 / 2012$ & $6 / 27 / 2012$ & $6 / 18 / 2012$ & $6 / 28 / 2012$ \\
\hline$n$ & $\begin{array}{l}\text { 10.Other } \\
\text { Equipment }\end{array}$ & $\begin{array}{l}\text { This addendum clarifies that the total lumens/watt for the entire elevator } \\
\text { cab is required to meet the efficiency requirement and it is not required } \\
\text { for each individual light source. }\end{array}$ & $6 / 27 / 2012$ & $6 / 27 / 2012$ & $6 / 18 / 2012$ & $6 / 28 / 2012$ \\
\hline 0 & $\begin{array}{l}\text { 5.Building } \\
\text { Envelope and } \\
\text { 3.Definitions }\end{array}$ & $\begin{array}{l}\text { This addendum adds the definition for sectional garage doors. It also } \\
\text { modifies Section 5.4.3.2 (d), fenestration air leakage provisions for } \\
\text { doors, to include requirements for glazed sectional garage doors. }\end{array}$ & $1 / 21 / 2012$ & $1 / 23 / 2012$ & $1 / 18 / 2012$ & $1 / 26 / 2012$ \\
\hline $\mathrm{p}$ & $\begin{array}{l}\text { 5.Building } \\
\text { Envelope and } \\
\text { 12.Normative } \\
\text { References }\end{array}$ & $\begin{array}{l}\text { This addendum modifies Section 5.5.3.1 and requires roof solar } \\
\text { reflectance and thermal emittance testing to be in accordance with Cool } \\
\text { Roof Rating Council (CRRC)-1 Standard. It also modifies Section } 12 \\
\text { by adding the reference for CRRC. }\end{array}$ & $1 / 21 / 2012$ & $1 / 23 / 2012$ & $1 / 18 / 2012$ & $1 / 26 / 2012$ \\
\hline q & $\begin{array}{l}\text { 5. Building } \\
\text { Envelope, } \\
\text { 3.Definitions } \\
\text { and } \\
\text { 12.Normative } \\
\text { References }\end{array}$ & $\begin{array}{l}\text { This addendum modifies Section 5.8.2.2, by clarifying the requirements } \\
\text { for labeling of fenestration and door products. The corresponding } \\
\text { references to NFRC in Chapter } 12 \text { have also been updated. }\end{array}$ & 6/27/2012 & $6 / 27 / 2012$ & 6/18/2012 & $6 / 28 / 2012$ \\
\hline$r$ & $\begin{array}{l}\text { Appendix G } \\
\text { and } \\
\text { 12.Normative } \\
\text { References }\end{array}$ & $\begin{array}{l}\text { This addendum clarifies the requirements related to temperature and } \\
\text { humidity control in Appendix G and relocates all related wording to the } \\
\text { Schedules section of Table 3.1. Additionally, clarity is provided for } \\
\text { modeling systems that provide occupant thermal comfort via means } \\
\text { other than other than directly controlling the air dry-bulb and wet-bulb } \\
\text { temperature (i.e., radiant cooling/heating, elevated air speed, etc.). It } \\
\text { permits the use of ASHRAE Standard } 55 \text { for calculation of PMV-PPD. } \\
\text { This addendum also updates the Normative References by including a } \\
\text { reference to ASHRAE Standard 55-2010. }\end{array}$ & $7 / 26 / 2013$ & 7/30/2013 & 7/29/2013 & $7 / 31 / 2013$ \\
\hline S & $\begin{array}{l}\text { 6. Heating, } \\
\text { Ventilating, } \\
\text { and Air- } \\
\text { Conditioning. }\end{array}$ & $\begin{array}{l}\text { This addendum modifies the requirement for the static pressure sensor } \\
\text { location and the control requirements for set point reset for systems with } \\
\text { direct digital control (DDC) of individual zones. Ensures that savings } \\
\text { from previously required static pressure reset will be realized. }\end{array}$ & $1 / 21 / 2012$ & $1 / 23 / 2012$ & $1 / 18 / 2012$ & $1 / 26 / 2012$ \\
\hline
\end{tabular}




\begin{tabular}{|c|c|c|c|c|c|c|}
\hline Addendum & $\begin{array}{c}\text { Section(s) } \\
\text { Affected }\end{array}$ & Description of Changes & $\begin{array}{l}\text { ASHRAE } \\
\text { Standards } \\
\text { Committee } \\
\text { Approval }\end{array}$ & $\begin{array}{l}\text { ASHRAE } \\
\text { BOD }\end{array}$ & $\begin{array}{l}\text { IES BOD } \\
\text { Approval }\end{array}$ & $\begin{array}{c}\text { ANSI } \\
\text { Approval }\end{array}$ \\
\hline $\mathrm{u}$ & $\begin{array}{l}\text { 6. Heating, } \\
\text { Ventilating, } \\
\text { and Air- } \\
\text { Conditioning. }\end{array}$ & $\begin{array}{l}\text { This addendum adds new definition for Fan Efficiency Grade (FEG) } \\
\text { and requires each fan has a FEG of } 67 \text { or higher as defined by Air } \\
\text { Movement and Control Association (AMCA) 205-10 (Energy } \\
\text { Efficiency Classification for Fans). }\end{array}$ & $1 / 26 / 2013$ & $1 / 29 / 2013$ & $2 / 11 / 2013$ & $2 / 12 / 2013$ \\
\hline $\mathrm{v}$ & 8.Power & $\begin{array}{l}\text { This addendum clarifies the requirement for controlled receptacles in } \\
\text { open offices. It also requires the automatically controlled receptacles to } \\
\text { be appropriately identified for the users benefit. }\end{array}$ & $1 / 26 / 2013$ & $1 / 29 / 2013$ & 2/11/2013 & $2 / 28 / 2013$ \\
\hline w & $\begin{array}{l}\text { 3.Definitions, } \\
\text { 11.Energy } \\
\text { Cost Budget } \\
\text { Method and } \\
\text { Appendix G. }\end{array}$ & $\begin{array}{l}\text { This addendum adds definitions for on-site renewable energy and } \\
\text { purchased energy. It clarifies the process for accounting for on-site } \\
\text { renewable energy and purchased energy as well as calculating the } \\
\text { annual energy costs in the energy cost budget (ECB) approach and } \\
\text { Appendix G. }\end{array}$ & $6 / 26 / 2013$ & $6 / 26 / 2013$ & $6 / 28 / 2013$ & $7 / 24 / 2013$ \\
\hline $\mathrm{y}$ & $\begin{array}{l}\text { 3.Definitions } \\
\text { and } 10 . \text { Other } \\
\text { Equipment }\end{array}$ & $\begin{array}{l}\text { This addendum revises the definitions of general purpose electric } \\
\text { motors (subtype I \&II) based on information from NEMA. It also } \\
\text { updates the standard to include the new federal energy efficiency } \\
\text { standards used in HVAC equipment, to be in effect from 2015. It adds } \\
\text { Table 10.8D (now Table 10.8-4 in Standard 90.1-2013), which specifies } \\
\text { minimum average full-load efficiency for Polyphase Small Electric } \\
\text { Motors; and Table 10.8E (now Table 10.8-5 in Standard 90.1-2013), } \\
\text { which specifies minimum average full-load efficiency for Capacitor- } \\
\text { Start Capacitor-Run and Capacitor-Start Induction-Run Small Electric } \\
\text { Motors. }\end{array}$ & $1 / 21 / 2012$ & $1 / 23 / 2012$ & $1 / 18 / 2012$ & $1 / 26 / 2012$ \\
\hline $\mathrm{z}$ & $\begin{array}{l}\text { 6. Heating, } \\
\text { Ventilating, } \\
\text { and Air- } \\
\text { Conditioning. }\end{array}$ & $\begin{array}{l}\text { This addendum relocates the requirements for water economizers into } \\
\text { the main economizer section, Section 6.5.1.5. }\end{array}$ & $1 / 21 / 2012$ & $1 / 23 / 2012$ & $1 / 18 / 2012$ & $1 / 26 / 2012$ \\
\hline aа & $\begin{array}{l}\text { 6. Heating, } \\
\text { Ventilating, } \\
\text { and Air- } \\
\text { Conditioning. }\end{array}$ & $\begin{array}{l}\text { Prior to this addendum certain controls requirements were only required } \\
\text { when the controls were provided by a DDC system. This addendum } \\
\text { eliminates that contingency for set point overlap restrictions, } \\
\text { humidification and dehumidification controls, variable air volume } \\
\text { (VAV) fan control set point reset, multiple-zone VAV system } \\
\text { ventilation optimization control, hydronic system design and control, } \\
\text { and instead specifies how the system must perform. This will in effect } \\
\text { require DDC for systems where these controls are needed. }\end{array}$ & $7 / 26 / 2013$ & $7 / 30 / 2013$ & $7 / 29 / 2013$ & 7/31/2013 \\
\hline
\end{tabular}




\begin{tabular}{|c|c|c|c|c|c|c|}
\hline Addendum & $\begin{array}{l}\text { Section(s) } \\
\text { Affected }\end{array}$ & Description of Changes & $\begin{array}{l}\text { ASHRAE } \\
\text { Standards } \\
\text { Committee } \\
\text { Approval }\end{array}$ & $\begin{array}{l}\text { ASHRAE } \\
\text { BOD }\end{array}$ & $\begin{array}{l}\text { IES BOD } \\
\text { Approval }\end{array}$ & $\begin{array}{c}\text { ANSI } \\
\text { Approval }\end{array}$ \\
\hline $\mathrm{ad}$ & $\begin{array}{l}\text { 12.Normative } \\
\text { References }\end{array}$ & $\begin{array}{l}\text { Adds reference to specific addenda to Air-Conditioning, Heating, and } \\
\text { Refrigeration Institute (AHRI) standards 340/360 and } 1230 \text { being } \\
\text { referenced. }\end{array}$ & $6 / 27 / 2012$ & $6 / 27 / 2012$ & $6 / 18 / 2012$ & $6 / 28 / 2012$ \\
\hline ae & $\begin{array}{l}\text { 12.Normative } \\
\text { References }\end{array}$ & $\begin{array}{l}\text { Adds reference to specific addenda to AHRI standards 210/240 and } \\
550 / 590 \text { being referenced. }\end{array}$ & $7 / 26 / 2013$ & 7/30/2013 & $7 / 29 / 2013$ & 8/28/2013 \\
\hline af & $\begin{array}{l}\text { 6. Heating, } \\
\text { Ventilating, } \\
\text { and Air- } \\
\text { Conditioning }\end{array}$ & $\begin{array}{l}\text { Modifies heat rejection equipment (cooling tower) requirements to } \\
\text { require variable speed drives on fans, operate all fans at the same speed } \\
\text { instead of sequencing them, and require that systems with multiple } \\
\text { condenser water pumps operate those pumps in parallel at reduced flow. }\end{array}$ & $6 / 26 / 2013$ & $6 / 26 / 2013$ & $6 / 28 / 2013$ & $7 / 1 / 2013$ \\
\hline ag & Appendix G & $\begin{array}{l}\text { Establishes a method for gaining credit in Appendix } G \text { for buildings that } \\
\text { undergo whole building air leakage testing to demonstrate that they } \\
\text { have an air-tight building. }\end{array}$ & $7 / 26 / 2013$ & 7/30/2013 & $7 / 29 / 2013$ & 8/28/2013 \\
\hline ah & Appendix G & $\begin{array}{l}\text { Sets system sizing requirements in Appendix G for humid climates } \\
\text { based on humidity ratio instead of Supply Air Temperature Differential. } \\
\text { Sets baseline system dehumidification requirements. }\end{array}$ & $6 / 27 / 2012$ & $6 / 27 / 2012$ & $6 / 18 / 2012$ & $6 / 28 / 2012$ \\
\hline ai & Appendix G & $\begin{array}{l}\text { Modifies Appendix G to account for } 3 \text { prescriptive addenda that were } \\
\text { incorporated in to Standard 90.1-2010, but did not make it into } \\
\text { Appendix G in time for publication. Updates economizer requirements } \\
\text { to match addendum cy, establishes baseline transformer efficiency } \\
\text { requirements to match addendum o, and establishes path A for } \\
\text { centrifugal chiller baselines from addendum m. }\end{array}$ & 6/27/2012 & 6/27/2012 & 6/18/2012 & 6/28/2012 \\
\hline aj & $\begin{array}{l}\text { 6. Heating, } \\
\text { Ventilating, } \\
\text { and Air- } \\
\text { Conditioning }\end{array}$ & $\begin{array}{l}\text { Requires fractional horsepower motors }>=1 / 22 \text { hp to EC motors or } \\
\text { minimum } 70 \% \text { efficient in accordance with DOE } 10 \text { CFR } 431 \text {. Also } \\
\text { requires adjustable speed or other method to balance airflow. }\end{array}$ & $6 / 26 / 2013$ & $6 / 26 / 2013$ & $6 / 28 / 2013$ & 7/1/2013 \\
\hline al & Appendix G & $\begin{array}{l}\text { Establishes a consistent fuel source for space heating for baseline } \\
\text { systems based on climate zone. Establishes a consistent fuel source for } \\
\text { service water heating based on building type. }\end{array}$ & 6/26/2013 & 6/26/2013 & 6/28/2013 & $7 / 24 / 2013$ \\
\hline am & $\begin{array}{l}\text { 6. Heating, } \\
\text { Ventilating, } \\
\text { and Air- } \\
\text { Conditioning }\end{array}$ & $\begin{array}{l}\text { Establishes minimum turndown for boilers and boiler plants with of at } \\
\text { least } 1,000,000 \mathrm{Btu} / \mathrm{h} \text {. }\end{array}$ & $6 / 26 / 2013$ & $6 / 26 / 2013$ & $6 / 28 / 2013$ & 7/1/2013 \\
\hline an & Appendix C & $\begin{array}{l}\text { Rewrites entire Appendix C to use a simulation based approach for } \\
\text { envelope trade-offs. }\end{array}$ & $7 / 26 / 2013$ & 7/30/2013 & $7 / 29 / 2013$ & 8/28/2013 \\
\hline
\end{tabular}




\begin{tabular}{|c|c|c|c|c|c|c|}
\hline Addendum & $\begin{array}{l}\text { Section(s) } \\
\text { Affected }\end{array}$ & Description of Changes & $\begin{array}{l}\text { ASHRAE } \\
\text { Standards } \\
\text { Committee } \\
\text { Approval }\end{array}$ & $\begin{array}{c}\text { ASHRAE } \\
\text { BOD }\end{array}$ & $\begin{array}{l}\text { IES BOD } \\
\text { Approval }\end{array}$ & $\begin{array}{c}\text { ANSI } \\
\text { Approval }\end{array}$ \\
\hline ap & $\begin{array}{l}\text { 6. Heating, } \\
\text { Ventilating, } \\
\text { and Air- } \\
\text { Conditioning }\end{array}$ & $\begin{array}{l}\text { Adds Power Utilization Effectiveness (PUE) as an alternative } \\
\text { compliance methodology for data centers. }\end{array}$ & $1 / 26 / 2013$ & $1 / 29 / 2013$ & $2 / 11 / 2013$ & $5 / 3 / 2013$ \\
\hline aq & $\begin{array}{l}\text { 6. Heating, } \\
\text { Ventilating, } \\
\text { and Air- } \\
\text { Conditioning } \\
\text { and } \\
\text { 11.Energy } \\
\text { Cost Budget }\end{array}$ & $\begin{array}{l}\text { This addendum makes changes to the requirements for fan control for } \\
\text { both constant volume and VAV units including extending the fan part } \\
\text { load power requirements down to } 1 / 4 \mathrm{hp} \text {. In addition it defines the } \\
\text { requirements for integrated economizer control and defines direct } \\
\text { expansion (DX) unit capacity staging requirements }\end{array}$ & 6/26/2013 & 6/26/2013 & 6/28/2013 & 7/1/2013 \\
\hline ar & $\begin{array}{l}\text { 6. Heating, } \\
\text { Ventilating, } \\
\text { and Air- } \\
\text { Conditioning }\end{array}$ & $\begin{array}{l}\text { Adds mandatory and prescriptive requirements for walk-in coolers and } \\
\text { freezers and refrigerated display cases. }\end{array}$ & $6 / 26 / 2013$ & $6 / 26 / 2013$ & $6 / 28 / 2013$ & 7/1/2013 \\
\hline as & $\begin{array}{l}\text { 6. Heating, } \\
\text { Ventilating, } \\
\text { and Air- } \\
\text { Conditioning }\end{array}$ & $\begin{array}{l}\text { Avoidance of simultaneous heating and cooling at air handling unit } \\
\text { (AHU). Requires humidifiers mounted in the airstream to have an } \\
\text { automatic control valve shutting off preheat when humidification is not } \\
\text { required, and insulation on the humidification system dispersion tube } \\
\text { surface. }\end{array}$ & $6 / 27 / 2012$ & 6/27/2012 & 6/18/2012 & $6 / 28 / 2012$ \\
\hline at & $\begin{array}{l}\text { 3. } \\
\text { Definitions, } \\
\text { 5.Building } \\
\text { Envelope, } \\
\text { and 9. } \\
\text { Lighting }\end{array}$ & $\begin{array}{l}\text { Deletes the term clerestory and instead adds roof monitor and clarifies } \\
\text { the definition. Changes the references in Chapters } 5 \text { and } 9 \text { from } \\
\text { clerestory to roof monitor. }\end{array}$ & $6 / 27 / 2012$ & $6 / 27 / 2012$ & $6 / 18 / 2012$ & $6 / 28 / 2012$ \\
\hline $\mathrm{au}$ & $\begin{array}{l}\text { 6. Heating, } \\
\text { Ventilating, } \\
\text { and Air- } \\
\text { Conditioning }\end{array}$ & $\begin{array}{l}\text { This addendum modifies Table 6.5.3.1.1B (now Table 6.5.3.1-2 in } \\
\text { Standard 90.1-2013) which addresses fan power limitation pressure } \\
\text { drop adjustment credits. Deductions are added for systems without any } \\
\text { central heating or cooling as well as systems with electric resistance } \\
\text { heating. Sound attenuation credit is modified to be available only when } \\
\text { there are background noise criteria requirements. }\end{array}$ & $1 / 26 / 2013$ & $1 / 29 / 2013$ & $2 / 11 / 2013$ & $2 / 12 / 2013$ \\
\hline av & $\begin{array}{l}\text { 6. Heating, } \\
\text { Ventilating, } \\
\text { and Air- } \\
\text { Conditioning }\end{array}$ & $\begin{array}{l}\text { This addendum modifies Section 6.5.1, exception } \mathrm{k} \text {, applicable to Tier } \\
\text { IV data centers, in an attempt to make economizer exceptions stricter } \\
\text { and in agreement with ASHRAE TC 9.9. }\end{array}$ & $6 / 26 / 2013$ & $6 / 26 / 2013$ & $6 / 28 / 2013$ & $7 / 24 / 2013$ \\
\hline
\end{tabular}




\begin{tabular}{|c|c|c|c|c|c|c|}
\hline Addendum & $\begin{array}{l}\text { Section(s) } \\
\text { Affected }\end{array}$ & Description of Changes & $\begin{array}{l}\text { ASHRAE } \\
\text { Standards } \\
\text { Committee } \\
\text { Approval }\end{array}$ & $\begin{array}{l}\text { ASHRAE } \\
\text { BOD }\end{array}$ & $\begin{array}{l}\text { IES BOD } \\
\text { Approval }\end{array}$ & $\begin{array}{c}\text { ANSI } \\
\text { Approval }\end{array}$ \\
\hline aw & $\begin{array}{l}\text { 11. Energy } \\
\text { Cost Budget } \\
\text { and Appendix } \\
\text { G }\end{array}$ & $\begin{array}{l}\text { This addendum updates the reference year for ASHRAE Standard } 140 \\
\text { and exempts software used for ECB and Appendix G compliance from } \\
\text { having to meet certain sections of ASHRAE Standard } 140 .\end{array}$ & $1 / 26 / 2013$ & $1 / 29 / 2013$ & $2 / 11 / 2013$ & $2 / 12 / 2013$ \\
\hline ax & Appendix G & $\begin{array}{l}\text { Table G3.1, Part } 14 \text { of Appendix G is modified to exclude the condition } \\
\text { that permits a building surface, shaded by an adjacent structure, to be } \\
\text { simulated as north facing if the simulation program is incapable of } \\
\text { simulating shading by adjacent structures. }\end{array}$ & $6 / 26 / 2013$ & $6 / 26 / 2013$ & $6 / 28 / 2013$ & $7 / 1 / 2013$ \\
\hline ay & $\begin{array}{l}\text { 3. } \\
\text { Definitions, } \\
\text { 9. Lighting }\end{array}$ & $\begin{array}{l}\text { This addendum modifies daylighting requirements. It modifies } \\
\text { definitions for daylight area under skylights, daylight area under roof } \\
\text { monitors, primary sidelighted area, and secondary sidelighted area. It } \\
\text { modifies the thresholds for applying automatic daylighting control for } \\
\text { sidelighting and toplighting, to a wattage basis and provides } \\
\text { characteristics for the required photo controls. It modifies Table 9.6.2 to } \\
\text { include continuous dimming in secondary sidelighted areas, which is } \\
\text { now based on a Watts level rather than area of the space. It eliminates } \\
\text { the need for effective aperture calculation. }\end{array}$ & $6 / 26 / 2013$ & $6 / 26 / 2013$ & $6 / 28 / 2013$ & $7 / 1 / 2013$ \\
\hline az & $\begin{array}{l}\text { 6. Heating, } \\
\text { Ventilating, } \\
\text { and Air- } \\
\text { Conditioning }\end{array}$ & $\begin{array}{l}\text { This addendum increases the minimum efficiency of open circuit axial } \\
\text { fan cooling towers. An additional requirement has been added which } \\
\text { states that the minimum efficiency requirements for all types of cooling } \\
\text { towers also applies to accessories that affect the thermal performance of } \\
\text { the unit. An additional footnote clarifies that the certification } \\
\text { requirements do not apply to field erected cooling towers. }\end{array}$ & $1 / 26 / 2013$ & $1 / 29 / 2013$ & $2 / 11 / 2013$ & $2 / 12 / 2013$ \\
\hline ba & $\begin{array}{l}\text { 6. Heating, } \\
\text { Ventilating, } \\
\text { and Air- } \\
\text { Conditioning }\end{array}$ & $\begin{array}{l}\text { Adds requirements for door switches to disable or reset mechanical } \\
\text { heating or cooling when doors are left open. }\end{array}$ & $7 / 26 / 2013$ & $7 / 30 / 2013$ & $7 / 29 / 2013$ & 8/28/2013 \\
\hline bc & 9. Lighting & $\begin{array}{l}\text { Modifies requirements for automatic lighting control for guestroom type } \\
\text { spaces. Exceptions to this requirement are lighting and switched } \\
\text { receptacles controlled by captive key systems. }\end{array}$ & $6 / 26 / 2013$ & $6 / 26 / 2013$ & $6 / 28 / 2013$ & $7 / 24 / 2013$ \\
\hline bd & 9. Lighting & $\begin{array}{l}\text { This addendum adds more specific requirements for the functional } \\
\text { testing of lighting controls, specifically, occupancy sensors, automatic } \\
\text { time switches and daylight controls. }\end{array}$ & 6/26/2013 & 6/26/2013 & $6 / 28 / 2013$ & 7/1/2013 \\
\hline be & 9. Lighting & $\begin{array}{l}\text { Minor revisions to Section 9.7.2.2, which addresses the scope of the } \\
\text { operating and maintenance manuals required for lighting equipment and } \\
\text { controls. }\end{array}$ & $1 / 26 / 2013$ & $1 / 29 / 2013$ & $2 / 11 / 2013$ & $2 / 12 / 2013$ \\
\hline
\end{tabular}




\begin{tabular}{|c|c|c|c|c|c|c|}
\hline Addendum & $\begin{array}{c}\text { Section(s) } \\
\text { Affected }\end{array}$ & Description of Changes & $\begin{array}{l}\text { ASHRAE } \\
\text { Standards } \\
\text { Committee } \\
\text { Approval }\end{array}$ & $\begin{array}{c}\text { ASHRAE } \\
\text { BOD }\end{array}$ & $\begin{array}{l}\text { IES BOD } \\
\text { Approval }\end{array}$ & $\begin{array}{c}\text { ANSI } \\
\text { Approval }\end{array}$ \\
\hline bf & 8. Power & $\begin{array}{l}\text { This addendum addresses Section } 8.4 .2 \text { on automatic receptacle control } \\
\text { and increases the spaces where plug shutoff control is required. It also } \\
\text { clarifies the application of this requirement for furniture systems, states } \\
\text { a labeling requirement to distinguish controlled and uncontrolled } \\
\text { receptacles and restricts the use of plug-in devices to comply with this } \\
\text { requirement. }\end{array}$ & $7 / 26 / 2013$ & $7 / 30 / 2013$ & $7 / 29 / 2013$ & $8 / 28 / 2013$ \\
\hline bg & $\begin{array}{l}\text { 5.Building } \\
\text { Envelope }\end{array}$ & Requirements for low-E storm window retrofits. & $6 / 26 / 2013$ & $6 / 26 / 2013$ & $6 / 28 / 2013$ & $7 / 1 / 2013$ \\
\hline bh & 9. Lighting & $\begin{array}{l}\text { Modifies Table 9.6.1 Space-By-Space Lighting Power Density } \\
\text { allowance. }\end{array}$ & $7 / 26 / 2013$ & 7/30/2013 & $8 / 12 / 2013$ & $9 / 4 / 2013$ \\
\hline bi & $\begin{array}{l}\text { 6. Heating, } \\
\text { Ventilating, } \\
\text { and Air- } \\
\text { Conditioning }\end{array}$ & $\begin{array}{l}\text { Increase seasonal energy efficiency ratio (SEER) and heating season } \\
\text { performance factor (HSPF) for air-cooled commercial air conditioners } \\
\text { and heat pumps below 65,000 Btu/h. Effective 1/1/2015. }\end{array}$ & $6 / 26 / 2013$ & $6 / 26 / 2013$ & $6 / 28 / 2013$ & $7 / 1 / 2013$ \\
\hline bj & $\begin{array}{l}\text { 6. Heating, } \\
\text { Ventilating, } \\
\text { and Air- } \\
\text { Conditioning. }\end{array}$ & $\begin{array}{l}\text { Re-establishes the product class for Small Duct High Velocity (SDHV) } \\
\text { air conditioners and heart pumps. Adds efficiency requirements for } \\
\text { systems at }<65.000 \mathrm{Btu} / \mathrm{h} \text {. }\end{array}$ & $6 / 26 / 2013$ & $6 / 26 / 2013$ & $6 / 28 / 2013$ & $7 / 1 / 2013$ \\
\hline bk & $\begin{array}{l}\text { 6. Heating, } \\
\text { Ventilating, } \\
\text { and Air- } \\
\text { Conditioning }\end{array}$ & $\begin{array}{l}\text { Increases cooling efficiency for packaged terminal air conditioners } \\
\text { (PTACs). }\end{array}$ & $1 / 26 / 2013$ & $1 / 29 / 2013$ & $2 / 11 / 2013$ & $2 / 12 / 2013$ \\
\hline bl & $\begin{array}{l}\text { 11.Energy } \\
\text { Cost Budget } \\
\text { and Appendix } \\
\text { G }\end{array}$ & $\begin{array}{l}\text { Provide rules for removing fan energy from efficiency metrics when } \\
\text { modeling in ECB or Appendix G. }\end{array}$ & $7 / 26 / 2013$ & 7/30/2013 & $7 / 29 / 2013$ & $7 / 31 / 2013$ \\
\hline bn & $\begin{array}{l}\text { 8. Power and } \\
\text { 10. Other } \\
\text { Equipment }\end{array}$ & Establishes electric and fuel metering requirements. & $7 / 26 / 2013$ & 7/30/2013 & $7 / 29 / 2013$ & 9/4/2013 \\
\hline bo & $\begin{array}{l}\text { 7. Service } \\
\text { Water } \\
\text { Heating }\end{array}$ & $\begin{array}{l}\text { Requires buildings with service water heating capacity }>=1 \text { million } \\
\text { Btu/h to have average efficiency of at least } 90 \% \text {. Updates Table } 7.8 \text { to } \\
\text { reflect federal requirements for electric water heaters. Updates the } \\
\text { reference standard for swimming pool water heaters to ASHRAE } \\
\text { Standard } 146 \text {. }\end{array}$ & $7 / 26 / 2013$ & 7/30/2013 & $7 / 29 / 2013$ & $9 / 4 / 2013$ \\
\hline
\end{tabular}




\begin{tabular}{|c|c|c|c|c|c|c|}
\hline Addendum & $\begin{array}{l}\text { Section(s) } \\
\text { Affected }\end{array}$ & Description of Changes & $\begin{array}{l}\text { ASHRAE } \\
\text { Standards } \\
\text { Committee } \\
\text { Approval }\end{array}$ & $\begin{array}{l}\text { ASHRAE } \\
\text { BOD }\end{array}$ & $\begin{array}{l}\text { IES BOD } \\
\text { Approval }\end{array}$ & $\begin{array}{c}\text { ANSI } \\
\text { Approval }\end{array}$ \\
\hline bp & $\begin{array}{l}\text { 6. Heating, } \\
\text { Ventilating, } \\
\text { and Air- } \\
\text { Conditioning }\end{array}$ & $\begin{array}{l}\text { Adds efficiency requirements (Btu/h-hp) to Table 6.8.1G (now Table } \\
\text { 6.8.1-7 in Standard 90.1-2013) for evaporative condensers with } \\
\text { ammonia refrigerants. }\end{array}$ & $7 / 26 / 2013$ & $7 / 30 / 2013$ & $7 / 29 / 2013$ & $7 / 31 / 2013$ \\
\hline bq & $\begin{array}{l}\text { 6. Heating, } \\
\text { Ventilating, } \\
\text { and Air- } \\
\text { Conditioning }\end{array}$ & Improve efficiency of commercial refrigeration systems. & $1 / 26 / 2013$ & $1 / 29 / 2013$ & $2 / 11 / 2013$ & $2 / 12 / 2013$ \\
\hline $\mathrm{br}$ & $\begin{array}{l}\text { 10. Other } \\
\text { Equipment }\end{array}$ & Updates motor efficiency tables. & $6 / 26 / 2013$ & $6 / 26 / 2013$ & $6 / 28 / 2013$ & $7 / 1 / 2013$ \\
\hline bs & $\begin{array}{l}\text { 6. Heating, } \\
\text { Ventilating, } \\
\text { and Air- } \\
\text { Conditioning }\end{array}$ & $\begin{array}{l}\text { Reduce occupancy threshold for demand controlled ventilation from } \\
\text { greater than } 40 \text { people per } 1000 \mathrm{ft}^{2} \text { to equal to or greater than } 25 \text { people } \\
\text { per } 1000 \mathrm{ft}^{2} \text { with exemptions for certain occupancies. }\end{array}$ & $7 / 26 / 2013$ & $7 / 30 / 2013$ & $7 / 29 / 2013$ & $7 / 31 / 2013$ \\
\hline bt & $\begin{array}{l}\text { 6. Heating, } \\
\text { Ventilating, } \\
\text { and Air- } \\
\text { Conditioning }\end{array}$ & $\begin{array}{l}\text { Reduces the threshold at which energy recovery is required. Relaxed in } \\
\text { some climate zones. }\end{array}$ & $6 / 26 / 2013$ & $6 / 26 / 2013$ & $6 / 28 / 2013$ & $7 / 24 / 2013$ \\
\hline bv & 9. Lighting & $\begin{array}{l}\text { Reduces the threshold at which skylights and daylighting controls are } \\
\text { required for high bay spaces. }\end{array}$ & $6 / 26 / 2013$ & $6 / 26 / 2013$ & $6 / 28 / 2013$ & $7 / 1 / 2013$ \\
\hline bw & $\begin{array}{l}\text { 5.Building } \\
\text { Envelope }\end{array}$ & $\begin{array}{l}\text { Modifies orientation requirements and adds solar heat gain coefficient } \\
\text { (SHGC) tradeoff. }\end{array}$ & $7 / 26 / 2013$ & $7 / 30 / 2013$ & $7 / 29 / 2013$ & $8 / 28 / 2013$ \\
\hline bx & 9. Lighting & Clarification of exceptions to occupancy sensor requirements. & $1 / 26 / 2013$ & $1 / 29 / 2013$ & $2 / 11 / 2013$ & 2/12/2013 \\
\hline by & 9.Lighting & $\begin{array}{l}\text { Improves and enhances lighting controls requirements. Establishes } \\
\text { table of lighting controls applicable to each space type. Corrects } \\
\text { daylighting threshold. }\end{array}$ & $7 / 26 / 2013$ & $7 / 30 / 2013$ & $7 / 29 / 2013$ & $8 / 28 / 2013$ \\
\hline са & $\begin{array}{l}\text { 5.Building } \\
\text { Envelope }\end{array}$ & Adds control requirements for heating systems in vestibules. & $6 / 26 / 2013$ & $6 / 26 / 2013$ & $6 / 28 / 2013$ & $7 / 1 / 2013$ \\
\hline $\mathrm{cb}$ & $\begin{array}{l}\text { 6. Heating, } \\
\text { Ventilating, } \\
\text { and Air- } \\
\text { Conditioning }\end{array}$ & $\begin{array}{l}\text { This addendum requires night setback } 10^{\circ} \mathrm{F} \text { heating and } 5^{\circ} \mathrm{F} \text { cooling and } \\
\text { removes exception for systems less than } 10,000 \mathrm{cfm} \text { min for optimum } \\
\text { start. }\end{array}$ & $7 / 26 / 2013$ & $7 / 30 / 2013$ & 7/29/2013 & $8 / 28 / 2013$ \\
\hline $\mathrm{CC}$ & $\begin{array}{l}\text { 6. Heating, } \\
\text { Ventilating, } \\
\text { and Air- } \\
\text { Conditioning }\end{array}$ & $\begin{array}{l}\text { Adds efficiency requirements (Btu/h-hp) to Table 6.8.1G (now Table } \\
\text { 6.8.1-7 in Standard 90.1-2013) for evaporative condensers with R- } \\
\text { 507A. }\end{array}$ & 6/26/2013 & 6/26/2013 & $6 / 28 / 2013$ & 7/1/2013 \\
\hline
\end{tabular}




\begin{tabular}{|c|c|c|c|c|c|c|}
\hline Addendum & $\begin{array}{l}\text { Section(s) } \\
\text { Affected }\end{array}$ & Description of Changes & $\begin{array}{l}\text { ASHRAE } \\
\text { Standards } \\
\text { Committee } \\
\text { Approval }\end{array}$ & $\begin{array}{l}\text { ASHRAE } \\
\text { BOD }\end{array}$ & $\begin{array}{l}\text { IES BOD } \\
\text { Approval }\end{array}$ & $\begin{array}{c}\text { ANSI } \\
\text { Approval }\end{array}$ \\
\hline cd & $\begin{array}{l}\text { 6. Heating, } \\
\text { Ventilating, } \\
\text { and Air- } \\
\text { Conditioning }\end{array}$ & $\begin{array}{l}\text { Provides definition for piping to include all accessories in series with } \\
\text { pipe such as pumps, valves, strainers, air separators, etc. This is meant } \\
\text { to clarify that these accessories need to be insulated. }\end{array}$ & $7 / 26 / 2013$ & $7 / 30 / 2013$ & $7 / 29 / 2013$ & $8 / 28 / 2013$ \\
\hline се & Appendix G & $\begin{array}{l}\text { Establishes a baseline system type for retail occupancies less than } 3 \\
\text { stories in Appendix G. }\end{array}$ & $6 / 26 / 2013$ & $6 / 26 / 2013$ & $6 / 28 / 2013$ & $7 / 1 / 2013$ \\
\hline $\mathrm{cf}$ & Appendix G & Establishes baseline window-to-wall ratio in Appendix G for strip malls. & $7 / 26 / 2013$ & $7 / 30 / 2013$ & $7 / 29 / 2013$ & $8 / 28 / 2013$ \\
\hline ch & $\begin{array}{l}\text { 6. Heating, } \\
\text { Ventilating, } \\
\text { and Air- } \\
\text { Conditioning }\end{array}$ & $\begin{array}{l}\text { Improved air and water cooled chiller efficiencies in Table 6.8.1C (now } \\
\text { Table 6.8.1-3 in Standard 90.1-2013). Exempts water cooled positive } \\
\text { displacement chillers with leaving condenser temperature } \geq 115^{\circ} \mathrm{F} \text {. } \\
\text { (typically heat reclaim chillers). }\end{array}$ & $6 / 26 / 2013$ & $6 / 26 / 2013$ & $6 / 28 / 2013$ & $7 / 1 / 2013$ \\
\hline ck & $\begin{array}{l}\text { 6. Heating, } \\
\text { Ventilating, } \\
\text { and Air- } \\
\text { Conditioning }\end{array}$ & $\begin{array}{l}\text { Requires VAV dual maximum damper position when DDC system is } \\
\text { present. }\end{array}$ & $6 / 26 / 2013$ & $6 / 26 / 2013$ & $6 / 28 / 2013$ & 7/1/2013 \\
\hline $\mathrm{cl}$ & $\begin{array}{l}\text { 6. Heating, } \\
\text { Ventilating, } \\
\text { and Air- } \\
\text { Conditioning }\end{array}$ & $\begin{array}{l}\text { Table 6.8.1A and B. (Now Tables 6.8.1-1 and 6.8.1-2 in Standard 90.1- } \\
\text { 2013) Improves integrated energy efficiency ratio (IEER) requirements } \\
\text { for air-cooled air conditioners and heat pumps and EER requirements } \\
\text { for water and evaporatively cooled air conditioners and heat pumps. }\end{array}$ & 7/26/2013 & 7/30/2013 & 7/29/2013 & 7/31/2013 \\
\hline $\mathrm{cn}$ & Appendix G & $\begin{array}{l}\text { Establishes modeling rules for laboratories with } 100 \% \text { outdoor air in } \\
\text { Appendix G. }\end{array}$ & $6 / 26 / 2013$ & $6 / 26 / 2013$ & $6 / 28 / 2013$ & 7/1/2013 \\
\hline $\mathrm{CO}$ & 9.Lighting & $\begin{array}{l}\text { Comprehensive update of lighting power densities (LPDs) in Table } \\
\text { 9.5.1 - Building Area Method. }\end{array}$ & 7/26/2013 & 7/30/2013 & 7/29/2013 & 7/31/2013 \\
\hline ср & $\begin{array}{l}\text { 5.Building } \\
\text { Envelope }\end{array}$ & $\begin{array}{l}\text { Corrects non-residential U-factor and R-value requirements for steel } \\
\text { joist floors in CZ3. }\end{array}$ & 6/26/2013 & 6/26/2013 & $6 / 28 / 2013$ & $7 / 1 / 2013$ \\
\hline $\mathrm{Cr}$ & 9.Lighting & Makes a number of adjustments to Table 9.6.1 Space-by-space LPD. & $7 / 26 / 2013$ & 7/30/2013 & $7 / 29 / 2013$ & 7/31/2013 \\
\hline ct & Appendix G & $\begin{array}{l}\text { Identifies heated only storage systems } 9 \text { and } 10 \text { in Appendix } G \text { as being } \\
\text { assigned one system per thermal zone. }\end{array}$ & $7 / 26 / 2013$ & $7 / 30 / 2013$ & $7 / 29 / 2013$ & $7 / 31 / 2013$ \\
\hline $\mathrm{CV}$ & Appendix G & $\begin{array}{l}\text { Establishes baseline system types in Appendix G for Assembly } \\
\text { occupancies. }\end{array}$ & $7 / 26 / 2013$ & $7 / 30 / 2013$ & $7 / 29 / 2013$ & $7 / 31 / 2013$ \\
\hline cy & $\begin{array}{l}\text { 6. Heating, } \\
\text { Ventilating, } \\
\text { and Air- } \\
\text { Conditioning }\end{array}$ & More stringent energy recovery for 24/7 occupancies. & $7 / 26 / 2013$ & $7 / 30 / 2013$ & $7 / 29 / 2013$ & $7 / 31 / 2013$ \\
\hline
\end{tabular}




\begin{tabular}{|c|c|c|c|c|c|c|}
\hline Addendum & $\begin{array}{l}\text { Section(s) } \\
\text { Affected }\end{array}$ & Description of Changes & $\begin{array}{l}\text { ASHRAE } \\
\text { Standards } \\
\text { Committee } \\
\text { Approval }\end{array}$ & $\begin{array}{l}\text { ASHRAE } \\
\text { BOD }\end{array}$ & $\begin{array}{l}\text { IES BOD } \\
\text { Approval }\end{array}$ & $\begin{array}{c}\text { ANSI } \\
\text { Approval }\end{array}$ \\
\hline $\mathrm{CZ}$ & $\begin{array}{l}\text { 6. Heating, } \\
\text { Ventilating, } \\
\text { and Air- } \\
\text { Conditioning }\end{array}$ & $\begin{array}{l}\text { Increases boiler efficiency for residential sized (National Appliance } \\
\text { Energy Conservation Act (NAECA) covered) equipment, <3,000 Btu/h. }\end{array}$ & $7 / 26 / 2013$ & 7/30/2013 & 7/29/2013 & $7 / 31 / 2013$ \\
\hline da & $\begin{array}{l}\text { 5.Building } \\
\text { Envelope }\end{array}$ & $\begin{array}{l}\text { Relaxes air leakage requirements for high-speed doors for vehicle } \\
\text { access and material transport. }\end{array}$ & $7 / 26 / 2013$ & 7/30/2013 & $7 / 29 / 2013$ & $8 / 28 / 2013$ \\
\hline $\mathrm{db}$ & $\begin{array}{l}\text { 5.Building } \\
\text { Envelope }\end{array}$ & $\begin{array}{l}\text { Corrects residential U-factor and R-value requirements for steel joist } \\
\text { floors in CZ3. }\end{array}$ & 7/26/2013 & 7/30/2013 & 7/29/2013 & 7/31/2013 \\
\hline dc & 9. Lighting & $\begin{array}{l}\text { Clarifies automatic lighting and switched receptacle control in guest } \\
\text { rooms as applied to individual spaces. }\end{array}$ & $7 / 26 / 2013$ & 7/30/2013 & 7/29/2013 & $7 / 31 / 2013$ \\
\hline dd & $\begin{array}{l}\text { 5.Building } \\
\text { Envelope }\end{array}$ & $\begin{array}{l}\text { Clarifies roof insulation requirements, differentiating between roof } \\
\text { recovering (on top of existing roof covering) and replacement of roof } \\
\text { covering. }\end{array}$ & $7 / 26 / 2013$ & 7/30/2013 & 7/29/2013 & 7/31/2013 \\
\hline de & $\begin{array}{l}\text { 6. Heating, } \\
\text { Ventilating, } \\
\text { and Air- } \\
\text { Conditioning }\end{array}$ & $\begin{array}{l}\text { Relaxes design requirements for waterside economizers for computer } \\
\text { rooms. }\end{array}$ & $7 / 26 / 2013$ & 7/30/2013 & $7 / 29 / 2013$ & $7 / 31 / 2013$ \\
\hline dg & $\begin{array}{l}\text { 5.Building } \\
\text { Envelope }\end{array}$ & Updates reference to ANSI/CRRC-l Standard 2012 (cool roof ratings). & $7 / 26 / 2013$ & $7 / 30 / 2013$ & $7 / 29 / 2013$ & $7 / 31 / 2013$ \\
\hline di & $\begin{array}{l}\text { 6. Heating, } \\
\text { Ventilating, } \\
\text { and Air- } \\
\text { Conditioning }\end{array}$ & $\begin{array}{l}\text { Establishes limits on using electric or fossil fuel to humidify or } \\
\text { dehumidify between } 30 \% \text { and } 60 \% \text { relative humidity (RH) except } \\
\text { certain applications. Requires deadband on humidity controls. }\end{array}$ & $7 / 26 / 2013$ & 7/30/2013 & $7 / 29 / 2013$ & $7 / 31 / 2013$ \\
\hline dj & 9.Lighting & $\begin{array}{l}\text { Additional lighting power allowance for electrical/mechanical rooms } \\
\text { provided there is separate control for additional lighting. }\end{array}$ & $7 / 26 / 2013$ & $7 / 30 / 2013$ & $7 / 29 / 2013$ & $7 / 31 / 2013$ \\
\hline $\mathrm{dk}$ & 9.Lighting & $\begin{array}{l}\text { Eliminates the exemption for wattage used in spaces where lighting is } \\
\text { specifically designed for those with age-related eye conditions or other } \\
\text { medical conditions related to the eye, where special lighting or light } \\
\text { levels might be needed. }\end{array}$ & $7 / 26 / 2013$ & 7/30/2013 & $7 / 29 / 2013$ & $8 / 28 / 2013$ \\
\hline dl & 9.Lighting & Modifies hotel and motel guest room LPD. & $7 / 26 / 2013$ & 7/30/2013 & 7/29/2013 & 8/28/2013 \\
\hline $\mathrm{dn}$ & $\begin{array}{l}\text { 6. Heating, } \\
\text { Ventilating, } \\
\text { and Air- } \\
\text { Conditioning }\end{array}$ & $\begin{array}{l}\text { Reduces the limits on hot gas bypass as a means of cooling capacity } \\
\text { control. }\end{array}$ & 7/26/2013 & 7/30/2013 & 7/29/2013 & 7/31/2013 \\
\hline
\end{tabular}




\begin{tabular}{|c|c|c|c|c|c|c|}
\hline Addendum & $\begin{array}{l}\text { Section(s) } \\
\text { Affected }\end{array}$ & Description of Changes & $\begin{array}{l}\text { ASHRAE } \\
\text { Standards } \\
\text { Committee } \\
\text { Approval }\end{array}$ & $\begin{array}{l}\text { ASHRAE } \\
\text { BOD }\end{array}$ & $\begin{array}{l}\text { IES BOD } \\
\text { Approval }\end{array}$ & $\begin{array}{c}\text { ANSI } \\
\text { Approval }\end{array}$ \\
\hline do & $\begin{array}{l}\text { 6. Heating, } \\
\text { Ventilating, } \\
\text { and Air- } \\
\text { Conditioning }\end{array}$ & $\begin{array}{l}\text { Update references to AHRI 550, AMCA 500, ANSI Z21.10.3 \& Z21.47, } \\
\text { ASHRAE 90.1 \& 62.1, NEMA MG 1, \& National Fire Protection } \\
\text { Association (NFPA) } 70 \text { \& 96. }\end{array}$ & $7 / 26 / 2013$ & 7/30/2013 & $7 / 29 / 2013$ & $7 / 31 / 2013$ \\
\hline dp & $\begin{array}{l}\text { 6. Heating, } \\
\text { Ventilating } \\
\text { and Air } \\
\text { Conditioning }\end{array}$ & $\begin{array}{l}\text { Corrects the definition of walk-in-coolers to be consistent with federal } \\
\text { requirements. }\end{array}$ & $7 / 26 / 2013$ & 7/30/2013 & $7 / 29 / 2013$ & $7 / 31 / 2013$ \\
\hline $\mathrm{dq}$ & $\begin{array}{l}\text { 6. Heating, } \\
\text { Ventilating, } \\
\text { and Air- } \\
\text { Conditioning }\end{array}$ & Deletes sizing requirements for pipes >24". & $7 / 26 / 2013$ & $7 / 30 / 2013$ & $7 / 29 / 2013$ & $7 / 31 / 2013$ \\
\hline $\mathrm{dr}$ & $\begin{array}{l}\text { 5.Building } \\
\text { Envelope }\end{array}$ & $\begin{array}{l}\text { Clarifies definition of building entrances to exclude electrical room, } \\
\text { mechanical rooms, and other utility service entrances. }\end{array}$ & $7 / 26 / 2013$ & $7 / 30 / 2013$ & $7 / 29 / 2013$ & $7 / 31 / 2013$ \\
\hline $\mathrm{dt}$ & 9.Lighting & $\begin{array}{l}\text { Added exceptions for control of exterior lighting integral to signage. } \\
\text { Requires certain types of exterior lighting exempt from LPD } \\
\text { requirements to be separately controlled. }\end{array}$ & $7 / 26 / 2013$ & 7/30/2013 & $7 / 29 / 2013$ & 7/31/2013 \\
\hline $\mathrm{dv}$ & $\begin{array}{l}\text { 6. Heating, } \\
\text { Ventilating, } \\
\text { and Air- } \\
\text { Conditioning }\end{array}$ & $\begin{array}{l}\text { Establishes chiller and boiler fluid flow isolation requirements so there } \\
\text { is no flow through the equipment when not in use. }\end{array}$ & $7 / 26 / 2013$ & $7 / 30 / 2013$ & $7 / 29 / 2013$ & $7 / 31 / 2013$ \\
\hline dw & $\begin{array}{l}\text { 6. Heating, } \\
\text { Ventilating, } \\
\text { and Air- } \\
\text { Conditioning }\end{array}$ & $\begin{array}{l}\text { Revises high limit shutoff for air economizers. Add sensor accuracy } \\
\text { requirements. }\end{array}$ & $7 / 26 / 2013$ & $7 / 30 / 2013$ & $7 / 29 / 2013$ & $7 / 31 / 2013$ \\
\hline
\end{tabular}


Appendix B. Addenda Included in Quantitative Analysis and their Impact on Prototype Buildings 
Table B.1. Addenda Included in Quantitative Analysis and their Impact on Prototype Buildings

\begin{tabular}{|c|c|c|c|c|c|c|c|c|c|c|c|c|c|c|c|c|c|c|}
\hline $\begin{array}{l}\text { Addenda } \\
\text { to } 90.1- \\
2010\end{array}$ & $\begin{array}{l}\text { 90.1- } \\
2010 \\
\text { Sections } \\
\text { Affected }\end{array}$ & Description of Changes & 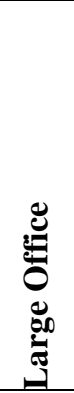 & 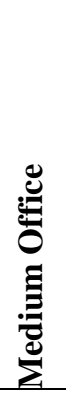 & 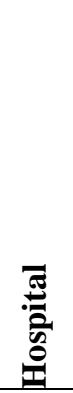 & 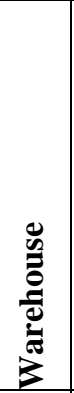 & 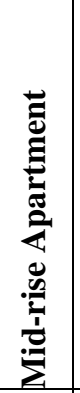 & 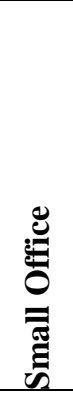 & 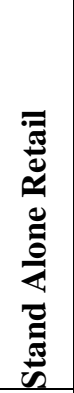 & 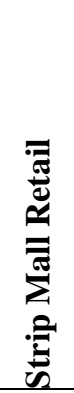 & 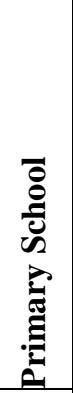 & 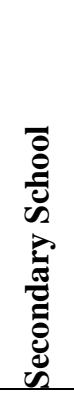 & 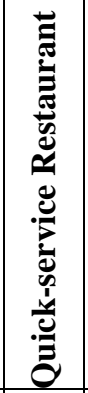 & 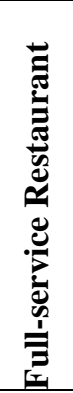 & 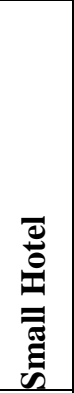 & 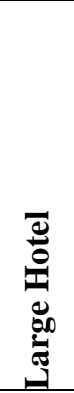 & 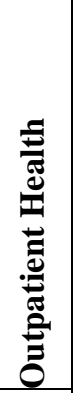 & 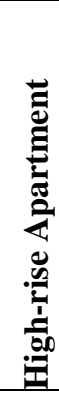 \\
\hline $\begin{array}{l}90.1- \\
2010 b b\end{array}$ & 5.5 & $\begin{array}{l}\text { Modifies the building envelope } \\
\text { requirements for opaque assemblies } \\
\text { and fenestration in Tables 5.5-1 } \\
\text { through 5.5-8. Adds and modifies text } \\
\text { in Section 5. Adds new visible } \\
\text { transmittance (VT) requirement } \\
\text { through Section 5.5.4.5. Also updates } \\
\text { the NFRC } 301 \text { reference, references in } \\
\text { Section } 11 \text { and modifies two metal } \\
\text { building roof assemblies in Table } \\
\text { A2.3. }\end{array}$ & $\mathrm{X}$ & $\mathrm{X}$ & $\mathrm{X}$ & $\mathrm{X}$ & $\mathrm{X}$ & $\mathrm{X}$ & $\mathrm{X}$ & $\mathrm{X}$ & $\mathrm{X}$ & $\mathrm{X}$ & $\mathrm{X}$ & $\mathrm{X}$ & $\mathrm{X}$ & $\mathrm{X}$ & $\mathrm{X}$ & $\mathrm{X}$ \\
\hline $\begin{array}{l}90.1- \\
2010 \mathrm{bw}\end{array}$ & 5.5.4.5 & $\begin{array}{l}\text { Modifies orientation requirements and } \\
\text { adds SHGC tradeoff. }\end{array}$ & & & $\mathrm{X}$ & & & & & & & & $\mathrm{X}$ & $\mathrm{X}$ & & & & \\
\hline $\begin{array}{l}90.1- \\
2010 \text { ca }\end{array}$ & 6.4.3.9 & $\begin{array}{l}\text { Adds control requirements for heating } \\
\text { systems in vestibules. }\end{array}$ & & & & & & & $\mathrm{X}$ & & & & & & & & & \\
\hline $\begin{array}{l}90.1- \\
2010 g^{*}\end{array}$ & 6.8 .1 & $\begin{array}{l}\text { Adds efficiency requirements for } \\
\text { commercial refrigerators, freezers and } \\
\text { refrigeration equipment. Table 6.8.1L } \\
\text { and Table 6.8.1M (now Tables 6.8.1- } \\
12 \text { and 6.8.1-13 in Standard 90.1- } \\
2013 \text { ) have been added which specify } \\
\text { the energy use limits for refrigerators } \\
\text { and freezers. The corresponding } \\
\text { references have also been added in } \\
\text { Chapter } 12 \text {. }\end{array}$ & & & $\mathrm{X}$ & & & & & & $\mathrm{X}$ & $\mathrm{X}$ & $\mathrm{X}$ & $\mathrm{X}$ & & $\mathrm{X}$ & & \\
\hline
\end{tabular}




\begin{tabular}{|c|c|c|c|c|c|c|c|c|c|c|c|c|c|c|c|c|c|c|}
\hline $\begin{array}{l}\text { Addenda } \\
\text { to } 90.1- \\
2010\end{array}$ & $\begin{array}{l}90.1- \\
2010 \\
\text { Sections } \\
\text { Affected }\end{array}$ & Description of Changes & 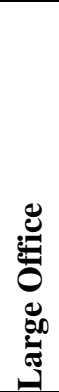 & 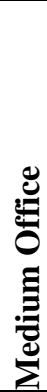 & 홀 & 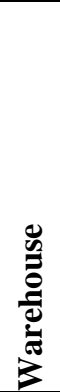 & 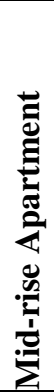 & 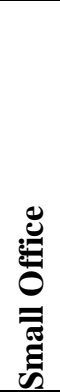 & 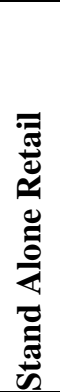 & 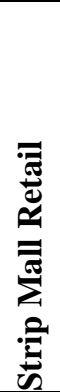 & 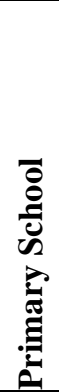 & 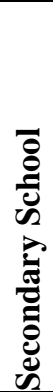 & 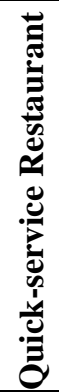 & 䒿 & 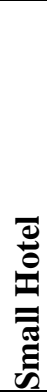 & 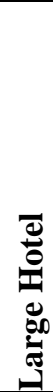 & ט̃ & 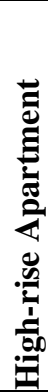 \\
\hline $\begin{array}{l}90.1- \\
2010 \mathrm{~h}\end{array}$ & 6.8 .1 & $\begin{array}{l}\text { Modifies the minimum efficiency } \\
\text { standards for water-to-air heat pumps } \\
\text { (water loop, ground water and ground } \\
\text { loop). The proposed cooling EERs } \\
\text { and heating coefficients of } \\
\text { performance are more stringent than } \\
\text { the present values. Also removes the } \\
\text { small duct high velocity heat pump } \\
\text { product class from Table 6.8.1B (now } \\
\text { Table 6.8.1-2 in Standard 90.1-2013). }\end{array}$ & & & & & & & & & & & & & & & & $\mathrm{X}$ \\
\hline $\begin{array}{l}\text { 90.1- } \\
\text { 2010af }\end{array}$ & 6.5 .5 & $\begin{array}{l}\text { Modifies heat rejection equipment } \\
\text { (cooling tower) requirements to } \\
\text { require that variable speed drive } \\
\text { controlled fans operate all fans at the } \\
\text { same speed instead of sequencing } \\
\text { them, and require that open-circuit } \\
\text { towers with multiple cells operate all } \\
\text { cells in parallel down to 50\% of } \\
\text { design flow. }\end{array}$ & $\mathrm{X}$ & & $\mathrm{X}$ & & & & & & & & & & & & & \\
\hline $\begin{array}{l}\text { 90.1- } \\
\text { 2010aj }\end{array}$ & 6.5.3.5 & $\begin{array}{l}\text { Requires fractional horsepower motors } \\
\geq 1 / 12 \text { hp to be electronically- } \\
\text { commutated motors or have a } \\
\text { minimum } 70 \% \text { efficiency in } \\
\text { accordance with DOE } 10 \text { CFR } 431 \text {. } \\
\text { Also requires adjustable speed or other } \\
\text { method to balance airflow. }\end{array}$ & $\mathrm{X}$ & $\mathrm{X}$ & $\mathrm{X}$ & & $\mathrm{X}$ & & & & $\mathrm{X}$ & $\mathrm{X}$ & $\mathrm{X}$ & $\mathrm{X}$ & $\mathrm{X}$ & $\mathrm{X}$ & $\mathrm{X}$ & $\mathrm{X}$ \\
\hline $\begin{array}{l}\text { 90.1- } \\
\text { 2010am }\end{array}$ & 6.5 .4 & $\begin{array}{l}\text { Establishes minimum turndown for } \\
\text { boilers and boiler plants with design } \\
\text { input power of at least 1,000,000 } \\
\text { Btu/h. }\end{array}$ & $\mathrm{X}$ & & $\mathrm{X}$ & & & & & & & $\mathrm{X}$ & & & & $\mathrm{X}$ & $\mathrm{X}$ & $\mathrm{X}$ \\
\hline
\end{tabular}




\begin{tabular}{|c|c|c|c|c|c|c|c|c|c|c|c|c|c|c|c|c|c|c|}
\hline $\begin{array}{l}\text { Addenda } \\
\text { to } 90.1- \\
2010\end{array}$ & $\begin{array}{l}90.1- \\
2010 \\
\text { Sections } \\
\text { Affected }\end{array}$ & Description of Changes & 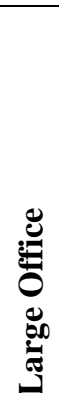 & 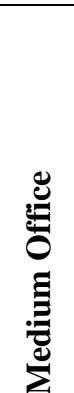 & స్ㅠ. & 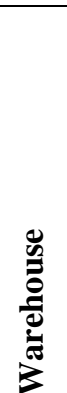 & 范 & 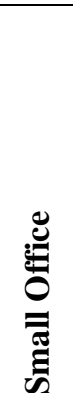 & 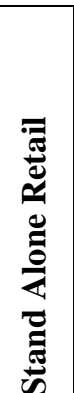 & 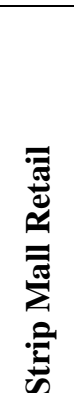 & 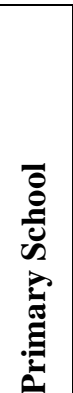 & 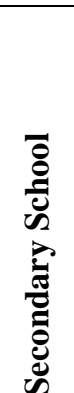 & 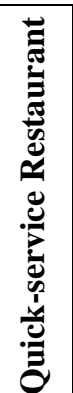 & 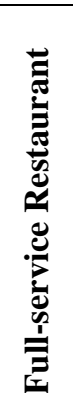 & 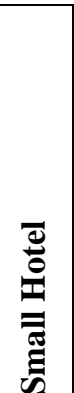 & 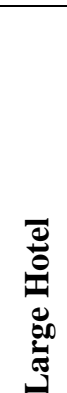 & 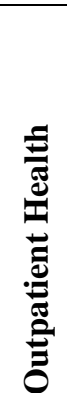 & \\
\hline $\begin{array}{l}\text { 90.1- } \\
\text { 2010aq }\end{array}$ & $\begin{array}{l}\text { 6. } 4.3 .10 \\
\text { 6.5.1.3 } \\
\text { 6.5.3.2.1 }\end{array}$ & $\begin{array}{l}\text { Expands the requirements for fan } \\
\text { speed control for both chilled water } \\
\text { and unitary direct expansion systems. } \\
\text { In addition enhances the requirements } \\
\text { for integrated economizer control and } \\
\text { defines DX unit capacity staging } \\
\text { requirements. }\end{array}$ & & & & & & & $\mathrm{X}$ & $\mathrm{X}$ & $\mathrm{X}$ & $\mathrm{X}$ & $\mathrm{X}$ & $\mathrm{X}$ & & & & \\
\hline $\begin{array}{l}90.1- \\
2010 \mathrm{ar}^{(\mathrm{a})}\end{array}$ & 6.8.1 & $\begin{array}{l}\text { Adds mandatory and prescriptive } \\
\text { requirements for walk-in coolers and } \\
\text { freezers and refrigerated display cases. }\end{array}$ & & & $\mathrm{X}$ & & & & & & $\mathrm{X}$ & $\mathrm{X}$ & $\mathrm{X}$ & $\mathrm{X}$ & & $\mathrm{X}$ & & \\
\hline $\begin{array}{l}90.1- \\
\text { 2010as }\end{array}$ & 6.5.2.4 & $\begin{array}{l}\text { Requires humidifiers mounted in the } \\
\text { airstream to have an automatic control } \\
\text { valve shutting off preheat when } \\
\text { humidification is not required, and } \\
\text { insulation on the humidification } \\
\text { system dispersion tube surface. } \\
\text { (Avoidance of simultaneous heating } \\
\text { and cooling at air handling unit.) }\end{array}$ & & & $\mathrm{X}$ & & & & & & & & & & & & $\mathrm{X}$ & \\
\hline $\begin{array}{l}90.1- \\
2010 \mathrm{au}\end{array}$ & 6.5.3.1.1 & $\begin{array}{l}\text { Modifies Table 6.5.3.1.1B (now Table } \\
\text { 6.5.3.1.1-2 in Standard 90.1-2013) } \\
\text { which addresses fan power limitation } \\
\text { pressure drop adjustment credits. } \\
\text { Deductions from allowed fan power } \\
\text { are added for systems without any } \\
\text { central heating or cooling as well as } \\
\text { systems with electric resistance } \\
\text { heating. Sound attenuation credit is } \\
\text { modified to be available only when } \\
\text { there are background noise criteria } \\
\text { requirements. }\end{array}$ & $\mathrm{X}$ & $\mathrm{X}$ & $\mathrm{X}$ & & & & & & $\mathrm{X}$ & $\mathrm{X}$ & & & & $\mathrm{X}$ & $\mathrm{X}$ & \\
\hline
\end{tabular}




\begin{tabular}{|c|c|c|c|c|c|c|c|c|c|c|c|c|c|c|c|c|c|c|}
\hline $\begin{array}{l}\text { Addenda } \\
\text { to } 90.1- \\
2010 \\
\end{array}$ & $\begin{array}{l}90.1- \\
2010 \\
\text { Sections } \\
\text { Affected }\end{array}$ & Description of Changes & 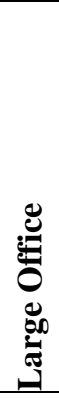 & 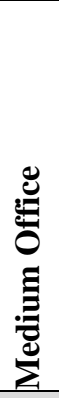 & 预 & 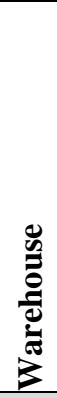 & 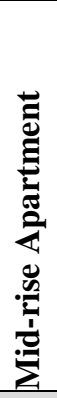 & 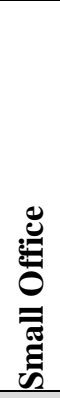 & 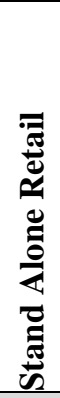 & 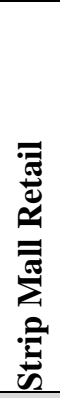 & 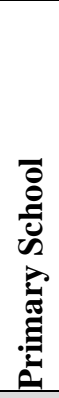 & 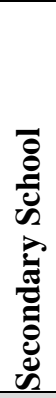 & 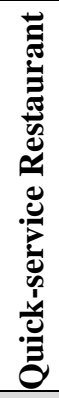 & 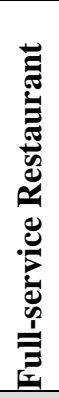 & 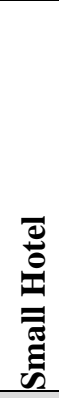 & 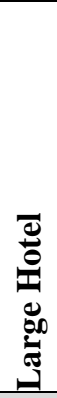 & 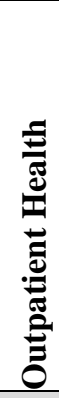 & 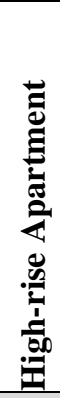 \\
\hline $\begin{array}{l}90.1- \\
2010 a z\end{array}$ & 6.8.1 & $\begin{array}{l}\text { Increases the minimum efficiency of } \\
\text { open circuit axial fan cooling towers. } \\
\text { An additional requirement has been } \\
\text { added for all types of cooling towers } \\
\text { which states that the minimum } \\
\text { efficiency requirements applies to the } \\
\text { tower including the capacity effect of } \\
\text { accessories which affect thermal } \\
\text { performance. An additional footnote } \\
\text { clarifies that the certification } \\
\text { requirements do not apply to field } \\
\text { erected cooling towers. }\end{array}$ & $\mathrm{X}$ & & $\mathrm{X}$ & & & & & & & & & & & & & \\
\hline $\begin{array}{l}\text { 90.1- } \\
\text { 2010ba }\end{array}$ & 6.5 .10 & $\begin{array}{l}\text { Adds requirements for door switches } \\
\text { to disable or reset mechanical heating } \\
\text { or cooling when doors without } \\
\text { automatic door closers are left open. }\end{array}$ & & & & & $\mathrm{X}$ & & & & & & & & $\mathrm{X}$ & $\mathrm{X}$ & & $\mathrm{X}$ \\
\hline $\begin{array}{l}90.1- \\
2010 b i\end{array}$ & 6.8 .1 & $\begin{array}{l}\text { Increase seasonal energy efficiency } \\
\text { ratio and heating seasonal } \\
\text { performance factor for air-cooled } \\
\text { commercial air conditioners and heat } \\
\text { pumps below } 65,000 \mathrm{Btu} / \mathrm{h} \text {. Effective } \\
1 / 1 / 2015 \text {. }\end{array}$ & & & & $\mathrm{X}$ & $\mathrm{X}$ & $\mathrm{X}$ & $\mathrm{X}$ & $\mathrm{X}$ & $\mathrm{X}$ & & $\mathrm{X}$ & $\mathrm{X}$ & $\mathrm{X}$ & & $\mathrm{X}$ & \\
\hline $\begin{array}{l}90.1- \\
\text { 2010bk }\end{array}$ & 6.8.1 & $\begin{array}{l}\text { Increases cooling efficiency for } \\
\text { packaged terminal air conditioners. }\end{array}$ & & & & & & & & & & & & & $\mathrm{X}$ & & & \\
\hline $\begin{array}{l}\text { 90.1- } \\
\text { 2010bs }\end{array}$ & 6.4.3.9 & $\begin{array}{l}\text { Reduces occupancy threshold for } \\
\text { demand controlled ventilation from } \\
\text { greater than } 40 \text { people per } 1000 \mathrm{ft}^{2} \text { to } \\
\text { equal to or greater than } 25 \text { people per } \\
1000 \mathrm{ft}^{2} \text { with exemptions for certain } \\
\text { occupancies. }\end{array}$ & & & & & & & & & $\mathrm{X}$ & $\mathrm{X}$ & & & & $\mathrm{X}$ & & \\
\hline
\end{tabular}




\begin{tabular}{|c|c|c|c|c|c|c|c|c|c|c|c|c|c|c|c|c|c|c|}
\hline $\begin{array}{l}\text { Addenda } \\
\text { to } 90.1- \\
2010 \\
\end{array}$ & $\begin{array}{l}90.1- \\
2010 \\
\text { Sections } \\
\text { Affected }\end{array}$ & Description of Changes & 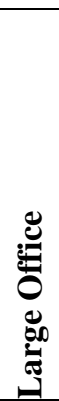 & 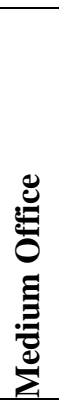 & 휼 & 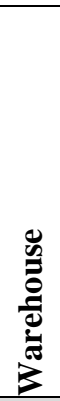 & 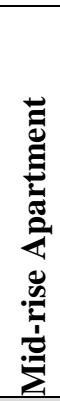 & 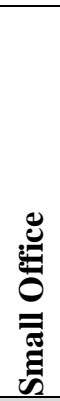 & 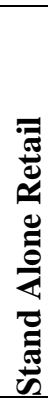 & 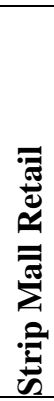 & 总 & 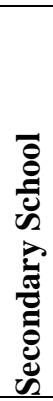 & 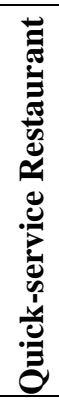 & 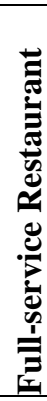 & 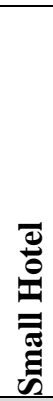 & 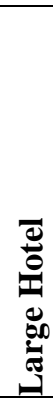 & D̃ & 葛 \\
\hline $\begin{array}{l}\text { 90.1- } \\
\text { 2010bt }\end{array}$ & 6.5.6.1 & $\begin{array}{l}\text { Reduces the system size and outdoor } \\
\text { air thresholds at which energy } \\
\text { recovery is required. Relaxed in some } \\
\text { climate zones. }\end{array}$ & $\mathrm{X}$ & $\mathrm{X}$ & $\mathrm{X}$ & & & & $\mathrm{X}$ & $\mathrm{X}$ & $\mathrm{X}$ & $\mathrm{X}$ & $\mathrm{X}$ & $\mathrm{X}$ & & $\mathrm{X}$ & $\mathrm{X}$ & \\
\hline $\begin{array}{l}90.1- \\
2010 \mathrm{cb}\end{array}$ & $\begin{array}{l}\text { 6.4.3.3.2, } \\
6.4 .3 .3 .3\end{array}$ & $\begin{array}{l}\text { Revises night setback requirements to } \\
\text { a reset of } 10^{\circ} \mathrm{F} \text { heating } \& 5^{\circ} \mathrm{F} \text { cooling } \\
\text { and removes exceptions for climate } \\
\text { zones. Changes optimum start } \\
\text { requirement from }>10,000 \mathrm{cfm} \text { to any } \\
\text { DDC system and adds a requirement } \\
\text { that outside air temperature be used in } \\
\text { optimum algorithms. }\end{array}$ & $\mathrm{X}$ & $\mathrm{X}$ & $\mathrm{X}$ & & & & $\mathrm{X}$ & & $\mathrm{X}$ & $\mathrm{X}$ & & & & $\mathrm{X}$ & $\mathrm{X}$ & $\mathrm{X}$ \\
\hline $\begin{array}{l}\text { 90.1- } \\
\text { 2010ch }\end{array}$ & 6.8 .1 & $\begin{array}{l}\text { Increases air- and water-cooled chiller } \\
\text { efficiencies in Table } 6.8 .1 \mathrm{C} \text { (now } \\
\text { Table } 6.8 .1-3 \text { in Standard } 90.1-2013 \text { ). } \\
\text { Exempts water-cooled positive } \\
\text { displacement chillers with leaving } \\
\text { condenser temperature } \geq 115^{\circ} \mathrm{F} \\
\text { (typically heat reclaim chillers). }\end{array}$ & $\mathrm{X}$ & & $\mathrm{X}$ & & & & & & & $\mathrm{X}$ & & & & $\mathrm{X}$ & & \\
\hline $\begin{array}{l}\text { 90.1- } \\
2010 \text { cy }\end{array}$ & 6.5.6.1 & $\begin{array}{l}\text { Reduces the design supply fan air flow } \\
\text { rate for which energy recovery is } \\
\text { required for systems that operate more } \\
\text { than } 8000 \text { hours per year. }\end{array}$ & & & $\mathrm{X}$ & & & & & & & & & & & $\mathrm{X}$ & & \\
\hline $\begin{array}{l}90.1- \\
2010 \mathrm{cz}^{(\mathrm{a})}\end{array}$ & 6.8 .1 & $\begin{array}{l}\text { Increases boiler efficiency for } \\
\text { residential sized (NAECA covered) } \\
\text { equipment, <3,000 Btu/h. }\end{array}$ & & & & & & & & & & & & & & & $\mathrm{X}$ & \\
\hline $\begin{array}{l}\text { 90.1- } \\
\text { 2010di }\end{array}$ & $\begin{array}{l}\text { 6.4.3.7, } \\
6.5 .2 .3\end{array}$ & $\begin{array}{l}\text { Establishes limits on using electricity } \\
\text { or fossil fuel to humidify or } \\
\text { dehumidify between } 30 \% \text { and } 60 \% \\
\text { RH except certain applications. }\end{array}$ & & & $\mathrm{X}$ & & & & & & & & & & & & $\mathrm{X}$ & \\
\hline
\end{tabular}




\begin{tabular}{|c|c|c|c|c|c|c|c|c|c|c|c|c|c|c|c|c|c|c|}
\hline $\begin{array}{l}\text { Addenda } \\
\text { to } 90.1- \\
2010\end{array}$ & $\begin{array}{l}90.1- \\
2010 \\
\text { Sections } \\
\text { Affected }\end{array}$ & Description of Changes & 蔍 & 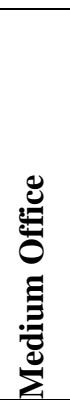 & 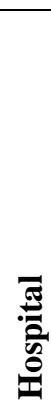 & 苞 & 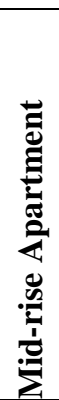 & 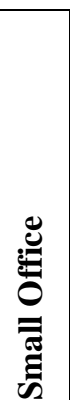 & 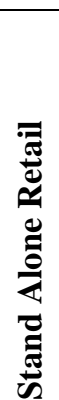 & 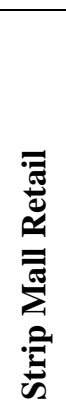 & 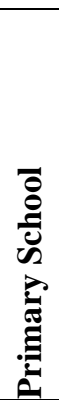 & 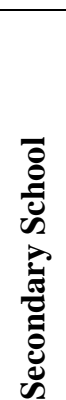 & 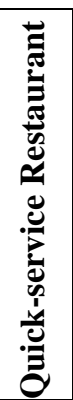 & 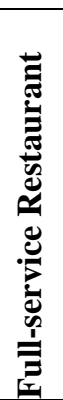 & 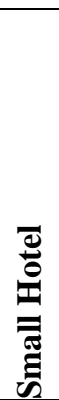 & 茪 & 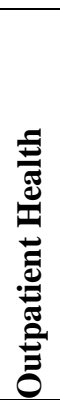 & 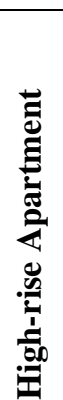 \\
\hline & & $\begin{array}{l}\text { Requires deadband on humidity } \\
\text { controls. }\end{array}$ & & & & & & & & & & & & & & & & \\
\hline $\begin{array}{l}90.1- \\
2010 \mathrm{dv}\end{array}$ & 6.5.4.2 & $\begin{array}{l}\text { Establishes chiller and boiler fluid } \\
\text { flow isolation requirements so there is } \\
\text { no flow through the equipment when } \\
\text { not in use. }\end{array}$ & $\mathrm{X}$ & & $\mathrm{X}$ & & & & & & & & & & & & & \\
\hline $\begin{array}{l}90.1- \\
2010 b f\end{array}$ & 8.4 .2 & $\begin{array}{l}\text { Addresses Section } 8.4 .2 \text { on automatic } \\
\text { receptacle control and increases the } \\
\text { spaces where plug shutoff control is } \\
\text { required. Clarifies the application of } \\
\text { this requirement for furniture systems, } \\
\text { lowers the threshold for turn off from } \\
30 \text { to } 20 \text { minutes, states a labeling } \\
\text { requirement to distinguish controlled } \\
\text { and uncontrolled receptacles and } \\
\text { restricts the use of plug-in devices to } \\
\text { comply with this requirement. }\end{array}$ & $\mathrm{X}$ & $\mathrm{X}$ & $\mathrm{X}$ & $\mathrm{X}$ & & $\mathrm{X}$ & $\mathrm{X}$ & & $\mathrm{X}$ & $\mathrm{X}$ & & $\mathrm{X}$ & $\mathrm{X}$ & $\mathrm{X}$ & $\mathrm{X}$ & \\
\hline
\end{tabular}




\begin{tabular}{|c|c|c|c|c|c|c|c|c|c|c|c|c|c|c|c|c|c|c|}
\hline $\begin{array}{l}\text { Addenda } \\
\text { to } 90.1- \\
2010\end{array}$ & $\begin{array}{l}90.1- \\
2010 \\
\text { Sections } \\
\text { Affected }\end{array}$ & Description of Changes & 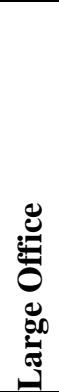 & 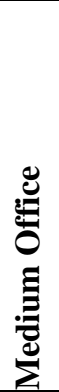 & ·플 & 苋 & 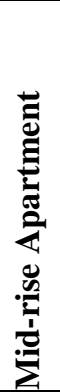 & 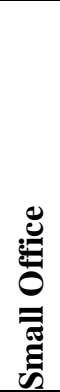 & 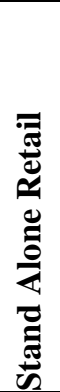 & 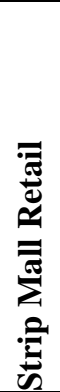 & 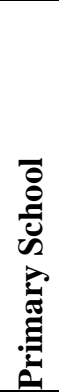 & 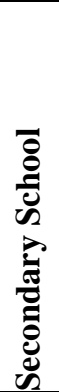 & 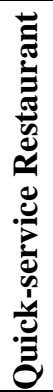 & 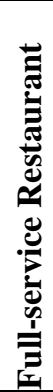 & 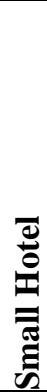 & 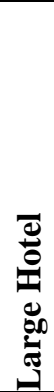 & 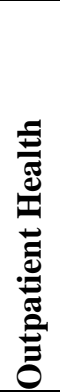 & 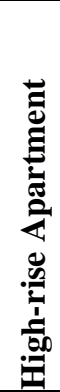 \\
\hline $\begin{array}{l}\text { 90.1- } \\
\text { 2010ay }\end{array}$ & $\begin{array}{l}9.4 .1 .4 \\
9.4 .1 .5\end{array}$ & $\begin{array}{l}\text { Modifies daylighting requirements. } \\
\text { Modifies definitions for daylight area } \\
\text { under skylights, daylight area under } \\
\text { roof monitors, primary sidelighted } \\
\text { area, and secondary sidelighted area. } \\
\text { Changes the criterion for applying } \\
\text { automatic daylighting control for } \\
\text { sidelighting and toplighting to a } \\
\text { controlled lighting power basis and } \\
\text { provides characteristics for the } \\
\text { required photo controls. Adds control } \\
\text { requirements for secondary sidelighted } \\
\text { areas. Modifies Table } 9.6 .2 \text { to include } \\
\text { continuous dimming in secondary } \\
\text { sidelighted areas, which is now based } \\
\text { on an installed wattage rather than } \\
\text { area of the space. Eliminates the need } \\
\text { for effective aperture calculation. }\end{array}$ & $\mathrm{X}$ & $\mathrm{X}$ & $\mathrm{X}$ & $\mathrm{X}$ & & $\mathrm{X}$ & & & $\mathrm{X}$ & $\mathrm{X}$ & $\mathrm{X}$ & $X$ & $\mathrm{X}$ & $\mathrm{X}$ & $\mathrm{X}$ & \\
\hline $\begin{array}{l}\text { 90.1- } \\
2010 b c\end{array}$ & 9.4.1.6 & $\begin{array}{l}\text { Modifies requirements for automatic } \\
\text { lighting control for guestroom type } \\
\text { spaces. Exceptions to this requirement } \\
\text { are lighting and switched receptacles } \\
\text { controlled by captive key systems. }\end{array}$ & & & & & & & & & & & & & $\mathrm{X}$ & $\mathrm{X}$ & & \\
\hline $\begin{array}{l}\text { 90.1- } \\
\text { 2010bh }\end{array}$ & 9.6 .1 & $\begin{array}{l}\text { Modifies Table 9.6.1 Space-By-Space } \\
\text { Lighting Power Density allowance. }\end{array}$ & $\mathrm{X}$ & $\mathrm{X}$ & $\mathrm{X}$ & $\mathrm{X}$ & $\mathrm{X}$ & $\mathrm{X}$ & $\mathrm{X}$ & $\mathrm{X}$ & $\mathrm{X}$ & $\mathrm{X}$ & $\mathrm{X}$ & $\mathrm{X}$ & $\mathrm{X}$ & $\mathrm{X}$ & $\mathrm{X}$ & $\mathrm{X}$ \\
\hline
\end{tabular}




\begin{tabular}{|c|c|c|c|c|c|c|c|c|c|c|c|c|c|c|c|c|c|c|}
\hline $\begin{array}{l}\text { Addenda } \\
\text { to } 90.1- \\
2010\end{array}$ & $\begin{array}{l}90.1- \\
2010 \\
\text { Sections } \\
\text { Affected }\end{array}$ & Description of Changes & 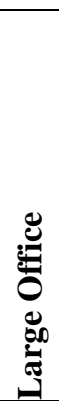 & 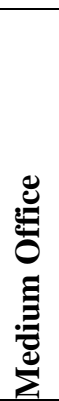 & 퓰 & 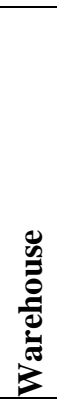 & 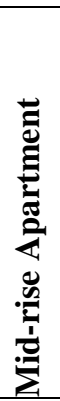 & 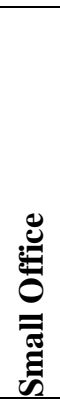 & 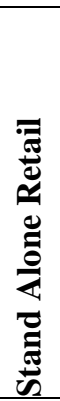 & 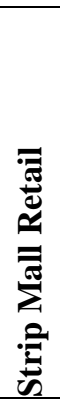 & 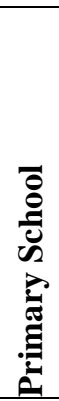 & 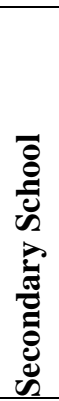 & 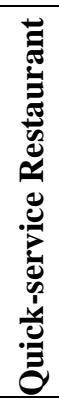 & 莺 & 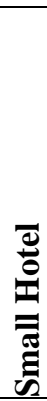 & 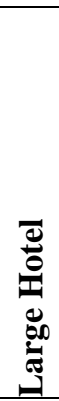 & 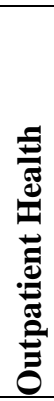 & 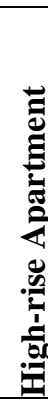 \\
\hline $\begin{array}{l}90.1- \\
2010 b y\end{array}$ & 9.4 .1 & $\begin{array}{l}\text { Significantly modifies the way } \\
\text { requirements are presented in Section } \\
\text { 9. Requires the use of certain lighting } \\
\text { controls in more space types. Reduces } \\
\text { the amount of time after occupants } \\
\text { vacate a space for lights to be } \\
\text { automatically reduced or shut off. } \\
\text { Establishes table of lighting controls } \\
\text { applicable to each space type. }\end{array}$ & $\mathrm{X}$ & $\mathrm{X}$ & $\mathrm{X}$ & $\mathrm{X}$ & $\mathrm{X}$ & $\mathrm{X}$ & $\mathrm{X}$ & $\mathrm{X}$ & $\mathrm{X}$ & $\mathrm{X}$ & $\mathrm{X}$ & $\mathrm{X}$ & $\mathrm{X}$ & $\mathrm{X}$ & $\mathrm{X}$ & $\mathrm{X}$ \\
\hline $\begin{array}{l}\text { 90.1- } \\
\text { 2010co }\end{array}$ & 9.5 .1 & $\begin{array}{l}\text { Comprehensive update of lighting } \\
\text { power densities (LPDs) in Table 9.5.1 } \\
\text { - Building Area Method. }\end{array}$ & $\mathrm{X}$ & $\mathrm{X}$ & $\mathrm{X}$ & $\mathrm{X}$ & & $\mathrm{X}$ & & & $\mathrm{X}$ & $\mathrm{X}$ & & & & $\mathrm{X}$ & & \\
\hline $\begin{array}{l}90.1- \\
2010 \mathrm{cr}\end{array}$ & 9.6 .1 & $\begin{array}{l}\text { Makes a number of adjustments to } \\
\text { Table 9.6.1, Space-by-space LPD. }\end{array}$ & & & & & & & $\mathrm{X}$ & $\mathrm{X}$ & & & & & $\mathrm{X}$ & $\mathrm{X}$ & $\mathrm{X}$ & \\
\hline $\begin{array}{l}\text { 90.1- } \\
\text { 2010dj }\end{array}$ & 9.6 .1 & $\begin{array}{l}\text { Additional lighting power allowance } \\
\text { for electrical/mechanical rooms made } \\
\text { available to match } 2010 \text { level provided } \\
\text { there is separate control for the } \\
\text { additional lighting. }\end{array}$ & & & & & & & & & $\mathrm{X}$ & $\mathrm{X}$ & & & $\mathrm{X}$ & $\mathrm{X}$ & & \\
\hline $\begin{array}{l}90.1- \\
2010 d l\end{array}$ & 9.6 .1 & $\begin{array}{l}\text { Modifies hotel and motel guest room } \\
\text { lighting power density. }\end{array}$ & & & & & & & & & & & & & $\mathrm{X}$ & $\mathrm{X}$ & & \\
\hline
\end{tabular}

(a) Addendum is included in modeling for both Standard 90.1-2010 and Standard 90.1-2013 prototypes. Addenda 90.1-2010g, 90.1-2010ar, and 90.12010cz are included in this category 


\section{Appendix C. Comparison of Building Envelope Requirements in Standard 90.1-2010 and Addendum 90.1- 2010bb}

This appendix compares building envelope requirements from Standard 90.1-2010 and those required by addendum 90.1-2010bb.

Abbreviations used in tables below:

2010 Requirements in 90.1-2010

bb Requirements in addendum 90.1-2010bb 
Table C.1. Addendum 90.1-2010bb Changes to Opaque Envelope U-factor Requirements for Non-Residential Buildings

\begin{tabular}{|c|c|c|c|c|c|c|c|c|c|c|c|c|c|c|c|c|}
\hline & \multicolumn{16}{|c|}{ Climate Zone } \\
\hline & \multicolumn{2}{|c|}{1} & \multicolumn{2}{|c|}{2} & \multicolumn{2}{|c|}{3} & \multicolumn{2}{|c|}{4} & \multicolumn{2}{|c|}{5} & \multicolumn{2}{|c|}{6} & \multicolumn{2}{|c|}{7} & \multicolumn{2}{|c|}{8} \\
\hline & 2010 & $\mathrm{bb}$ & 2010 & $\mathrm{bb}$ & 2010 & $\mathrm{bb}$ & 2010 & $\mathrm{bb}$ & 2010 & $\mathrm{bb}$ & 2010 & $\mathrm{bb}$ & 2010 & bb & 2010 & $\mathrm{bb}$ \\
\hline IEAD Roof ${ }^{(a)}$ & 0.063 & 0.048 & 0.048 & 0.039 & 0.048 & 0.039 & 0.048 & 0.032 & 0.048 & 0.032 & 0.048 & 0.032 & 0.048 & 0.028 & 0.048 & 0.028 \\
\hline Metal Building Roof & 0.065 & 0.041 & 0.055 & 0.041 & 0.055 & 0.041 & 0.055 & 0.037 & 0.055 & 0.037 & 0.049 & 0.031 & 0.049 & 0.029 & 0.035 & 0.026 \\
\hline Attic Roof & 0.034 & 0.027 & 0.027 & 0.027 & 0.027 & 0.027 & 0.027 & 0.021 & 0.027 & 0.021 & 0.027 & 0.021 & 0.027 & 0.017 & 0.021 & 0.017 \\
\hline Mass Wall & 0.580 & 0.580 & 0.151 & 0.151 & 0.123 & 0.123 & 0.104 & 0.104 & 0.090 & 0.090 & 0.080 & 0.080 & 0.071 & 0.071 & 0.071 & 0.048 \\
\hline Metal Building Wall & 0.093 & 0.094 & 0.093 & 0.094 & 0.084 & 0.094 & 0.084 & 0.060 & 0.069 & 0.050 & 0.069 & 0.050 & 0.057 & 0.044 & 0.057 & 0.039 \\
\hline Steel-Frame Wall & 0.124 & 0.124 & 0.124 & 0.077 & 0.084 & 0.077 & 0.064 & 0.064 & 0.064 & 0.055 & 0.064 & 0.049 & 0.064 & 0.049 & 0.064 & 0.037 \\
\hline Wood-Frame Wall & 0.089 & 0.089 & 0.089 & 0.089 & 0.089 & 0.089 & 0.089 & 0.064 & 0.064 & 0.051 & 0.051 & 0.051 & 0.051 & 0.051 & 0.036 & 0.032 \\
\hline Below Ground Wall ${ }^{(b)}$ & 1.140 & 1.140 & 1.140 & 1.140 & 1.140 & 0.119 & 1.140 & 0.119 & 0.119 & 0.119 & 0.119 & 0.092 & 0.119 & 0.063 & 0.119 & 0.063 \\
\hline Mass Floor & 0.322 & 0.322 & 0.107 & 0.107 & 0.107 & 0.074 & 0.087 & 0.057 & 0.074 & 0.057 & 0.064 & 0.051 & 0.064 & 0.042 & 0.057 & 0.038 \\
\hline Steel-Joist Floor & 0.350 & 0.350 & 0.052 & 0.038 & 0.052 & 0.052 & 0.038 & 0.038 & 0.038 & 0.038 & 0.038 & 0.032 & 0.038 & 0.032 & 0.032 & 0.032 \\
\hline Wood-Framed Floor & 0.282 & 0.282 & 0.051 & 0.033 & 0.051 & 0.033 & 0.033 & 0.033 & 0.033 & 0.033 & 0.033 & 0.027 & 0.033 & 0.027 & 0.033 & 0.027 \\
\hline Unheated Slab on Grade ${ }^{(\mathrm{c})}$ & 0.730 & 0.730 & 0.730 & 0.730 & 0.730 & 0.730 & 0.730 & 0.520 & 0.730 & 0.520 & 0.540 & 0.510 & 0.520 & 0.510 & 0.520 & 0.434 \\
\hline Heated Slab on Grade ${ }^{(\mathrm{c})}$ & 1.020 & 1.020 & 1.020 & 0.900 & 0.900 & 0.860 & 0.860 & 0.843 & 0.860 & 0.688 & 0.860 & 0.688 & 0.843 & 0.671 & 0.688 & 0.671 \\
\hline $\begin{array}{l}\text { U-factors are expressed in } \\
\text { (a) IEAD: insulation entir } \\
\text { (b) Below ground wall rec } \\
\text { (c) Unheated and heated s }\end{array}$ & airemen & $\begin{array}{l}{ }^{\circ} \mathrm{F} . \\
\text { deck. } \\
\text { s are ex } \\
\text { ade requ }\end{array}$ & rement & are ex & $\begin{array}{l}\text { I L-Ia } \\
\text { essed }\end{array}$ & terms & $\begin{array}{l}\left.-\mathrm{ft}^{2}-{ }^{\circ} \mathrm{F}\right) \\
\mathrm{F} \text {-fact }\end{array}$ & (Btu & $\left.\mathrm{t}^{\circ} \mathrm{F}\right)$ & & & & & & & \\
\hline
\end{tabular}


Table C.2. Addendum 90.1-2010bb Changes to Opaque Envelope U-factor Requirements for Residential Buildings

\begin{tabular}{|c|c|c|c|c|c|c|c|c|c|c|c|c|c|c|c|c|}
\hline & \multicolumn{16}{|c|}{ Climate Zone } \\
\hline & \multicolumn{2}{|c|}{1} & \multicolumn{2}{|c|}{2} & \multicolumn{2}{|c|}{3} & \multicolumn{2}{|c|}{4} & \multicolumn{2}{|c|}{5} & \multicolumn{2}{|c|}{6} & \multicolumn{2}{|c|}{7} & \multicolumn{2}{|c|}{8} \\
\hline & 2010 & $\mathrm{bb}$ & 2010 & $\mathrm{bb}$ & 2010 & $\mathrm{bb}$ & 2010 & $\mathrm{bb}$ & 2010 & $\mathrm{bb}$ & 2010 & $\mathrm{bb}$ & 2010 & $\mathrm{bb}$ & 2010 & $\mathrm{bb}$ \\
\hline IEAD Roof ${ }^{(\mathrm{a})}$ & 0.048 & 0.039 & 0.048 & 0.039 & 0.048 & 0.039 & 0.048 & 0.032 & 0.048 & 0.032 & 0.048 & 0.032 & 0.048 & 0.028 & 0.048 & 0.028 \\
\hline Metal Building Roof & 0.065 & 0.041 & 0.055 & 0.041 & 0.055 & 0.041 & 0.055 & 0.037 & 0.055 & 0.037 & 0.049 & 0.029 & 0.049 & 0.029 & 0.035 & 0.026 \\
\hline Attic Roof & 0.027 & 0.027 & 0.027 & 0.027 & 0.027 & 0.027 & 0.027 & 0.021 & 0.027 & 0.021 & 0.027 & 0.021 & 0.027 & 0.017 & 0.021 & 0.017 \\
\hline Mass Wall & 0.151 & 0.151 & 0.123 & 0.123 & 0.104 & 0.104 & 0.090 & 0.090 & 0.080 & 0.080 & 0.071 & 0.071 & 0.071 & 0.071 & 0.052 & 0.048 \\
\hline Metal Building Wall & 0.093 & 0.094 & 0.093 & 0.094 & 0.084 & 0.072 & 0.084 & 0.050 & 0.069 & 0.050 & 0.069 & 0.050 & 0.057 & 0.044 & 0.057 & 0.039 \\
\hline Steel-Frame Wall & 0.124 & 0.124 & 0.064 & 0.064 & 0.064 & 0.064 & 0.064 & 0.064 & 0.064 & 0.055 & 0.064 & 0.049 & 0.042 & 0.049 & 0.037 & 0.037 \\
\hline Wood-Frame Wall & 0.089 & 0.089 & 0.089 & 0.089 & 0.089 & 0.064 & 0.064 & 0.064 & 0.051 & 0.051 & 0.051 & 0.051 & 0.051 & 0.051 & 0.036 & 0.032 \\
\hline Below Ground Wall ${ }^{(\mathrm{b})}$ & 1.140 & 1.140 & 1.140 & 1.140 & 1.140 & 0.119 & 0.119 & 0.092 & 0.119 & 0.092 & 0.119 & 0.063 & 0.092 & 0.063 & 0.075 & 0.063 \\
\hline Mass Floor & 0.322 & 0.322 & 0.087 & 0.087 & 0.087 & 0.074 & 0.074 & 0.051 & 0.064 & 0.051 & 0.057 & 0.051 & 0.051 & 0.042 & 0.051 & 0.038 \\
\hline Steel-Joist Floor & 0.350 & 0.350 & 0.052 & 0.038 & 0.052 & 0.032 & 0.038 & 0.038 & 0.038 & 0.038 & 0.032 & 0.032 & 0.032 & 0.032 & 0.032 & 0.032 \\
\hline Wood-Framed Floor & 0.282 & 0.282 & 0.033 & 0.033 & 0.033 & 0.033 & 0.033 & 0.033 & 0.033 & 0.033 & 0.033 & 0.027 & 0.033 & 0.027 & 0.033 & 0.027 \\
\hline Unheated Slab on Grade ${ }^{(\mathrm{c})}$ & 0.730 & 0.730 & 0.730 & 0.730 & 0.730 & 0.540 & 0.540 & 0.520 & 0.540 & 0.510 & 0.520 & 0.434 & 0.520 & 0.434 & 0.510 & 0.424 \\
\hline Heated Slab on Grade ${ }^{(\mathrm{c})}$ & 1.020 & 1.020 & 1.020 & 0.860 & 0.900 & 0.860 & 0.860 & 0.688 & 0.860 & 0.688 & 0.688 & 0.671 & 0.688 & 0.671 & 0.688 & 0.373 \\
\hline
\end{tabular}

U-factors are expressed in Btu/h-ft ${ }^{2}{ }^{\circ} \mathrm{F}$.

(a) IEAD: insulation entirely above deck.

(b) Below ground wall requirements are expressed in terms of $\mathrm{C}$-factor $\left(\mathrm{Btu} / \mathrm{h}-\mathrm{ft}^{2}{ }^{\circ} \mathrm{F}\right)$.

(c) Unheated and heated slab on grade requirements are expressed in terms of F-factor (Btu/h-ft- $\left.{ }^{\circ} \mathrm{F}\right)$. 
Table C.3. Addendum 90.1-2010bb Changes to Opaque Envelope U-factor Requirements for Semi-heated Buildings

\begin{tabular}{|c|c|c|c|c|c|c|c|c|c|c|c|c|c|c|c|c|}
\hline & \multicolumn{16}{|c|}{ Climate Zone } \\
\hline & \multicolumn{2}{|c|}{1} & \multicolumn{2}{|c|}{2} & \multicolumn{2}{|c|}{3} & \multicolumn{2}{|c|}{4} & \multicolumn{2}{|c|}{5} & \multicolumn{2}{|c|}{6} & \multicolumn{2}{|c|}{7} & \multicolumn{2}{|c|}{8} \\
\hline & 2010 & $\mathrm{bb}$ & 2010 & $\mathrm{bb}$ & 2010 & $\mathrm{bb}$ & 2010 & $\mathrm{bb}$ & 2010 & $\mathrm{bb}$ & 2010 & $\mathrm{bb}$ & 2010 & $\mathrm{bb}$ & 2010 & $\mathrm{bb}$ \\
\hline IEAD Roof ${ }^{(a)}$ & 0.218 & 0.218 & 0.218 & 0.173 & 0.173 & 0.119 & 0.173 & 0.093 & 0.119 & 0.063 & 0.093 & 0.063 & 0.093 & 0.039 & 0.063 & 0.039 \\
\hline Metal Building Roof & 0.167 & 0.115 & 0.097 & 0.096 & 0.097 & 0.096 & 0.097 & 0.082 & 0.083 & 0.082 & 0.072 & 0.060 & 0.072 & 0.037 & 0.065 & 0.037 \\
\hline Attic Roof & 0.081 & 0.081 & 0.081 & 0.053 & 0.053 & 0.053 & 0.053 & 0.034 & 0.053 & 0.034 & 0.034 & 0.034 & 0.034 & 0.027 & 0.034 & 0.027 \\
\hline Mass Wall & 0.580 & 0.580 & 0.580 & 0.580 & 0.580 & 0.580 & 0.580 & 0.580 & 0.151 & 0.151 & 0.151 & 0.151 & 0.123 & 0.123 & 0.104 & 0.104 \\
\hline Metal Building Wall & 0.113 & 0.352 & 0.113 & 0.162 & 0.113 & 0.162 & 0.113 & 0.162 & 0.113 & 0.094 & 0.113 & 0.094 & 0.113 & 0.072 & 0.113 & 0.060 \\
\hline Steel-Frame Wall & 0.352 & 0.352 & 0.124 & 0.124 & 0.124 & 0.124 & 0.124 & 0.124 & 0.124 & 0.084 & 0.124 & 0.084 & 0.124 & 0.064 & 0.084 & 0.064 \\
\hline Wood-Frame Wall & 0.292 & 0.292 & 0.089 & 0.089 & 0.089 & 0.089 & 0.089 & 0.089 & 0.089 & 0.089 & 0.089 & 0.089 & 0.089 & 0.064 & 0.089 & 0.051 \\
\hline Below Ground Wall ${ }^{(\mathrm{b})}$ & 1.140 & 1.140 & 1.140 & 1.140 & 1.140 & 1.140 & 1.140 & 1.140 & 1.140 & 1.140 & 1.140 & 0.119 & 1.140 & 0.119 & 1.140 & 0.119 \\
\hline Mass Floor & 0.322 & 0.322 & 0.322 & 0.322 & 0.322 & 0.137 & 0.137 & 0.107 & 0.137 & 0.107 & 0.137 & 0.087 & 0.107 & 0.074 & 0.087 & 0.064 \\
\hline Steel-Joist Floor & 0.350 & 0.350 & 0.069 & 0.069 & 0.069 & 0.052 & 0.069 & 0.052 & 0.052 & 0.052 & 0.052 & 0.052 & 0.052 & 0.052 & 0.052 & 0.052 \\
\hline Wood-Framed Floor & 0.282 & 0.282 & 0.066 & 0.066 & 0.066 & 0.051 & 0.066 & 0.051 & 0.051 & 0.051 & 0.051 & 0.051 & 0.051 & 0.051 & 0.033 & 0.033 \\
\hline Unheated Slab on Grade ${ }^{(\mathrm{c})}$ & 0.730 & 0.730 & 0.730 & 0.730 & 0.730 & 0.730 & 0.730 & 0.730 & 0.730 & 0.730 & 0.730 & 0.730 & 0.730 & 0.730 & 0.740 & 0.540 \\
\hline Heated Slab on Grade ${ }^{(\mathrm{c})}$ & 1.020 & 1.020 & 1.020 & 1.020 & 1.020 & 1.020 & 1.020 & 0.900 & 1.020 & 0.900 & 1.020 & 0.860 & 0.900 & 0.860 & 0.900 & 0.860 \\
\hline $\begin{array}{l}\text { U-factors are expressed in } \\
\text { (a) IEAD: insulation entir } \\
\text { (b) Below ground wall re } \\
\text { (c) Unheated and heated s }\end{array}$ & $\begin{array}{l}\mathrm{tu} / \mathrm{h}-\mathrm{ft}^{2} \\
\text { ly abov }\end{array}$ & $\begin{array}{l}{ }^{\circ} \mathrm{F} \text {. } \\
\text { deck. }\end{array}$ & essed & lemin & (c-ld & (DU & F-fact & (Dיס & $\left.\mathrm{t}^{\circ} \mathrm{F}\right)$. & & & & & & & \\
\hline
\end{tabular}


Table C.4. Addendum 90.1-2010bb Changes to Fenestration Requirements for Nonresidential Buildings

\begin{tabular}{|c|c|c|c|c|c|c|c|c|c|c|c|c|c|c|c|c|}
\hline & \multicolumn{16}{|c|}{ Climate Zone } \\
\hline & \multicolumn{2}{|c|}{1} & \multicolumn{2}{|c|}{2} & \multicolumn{2}{|c|}{3} & \multicolumn{2}{|c|}{4} & \multicolumn{2}{|c|}{5} & \multicolumn{2}{|c|}{6} & \multicolumn{2}{|c|}{7} & \multicolumn{2}{|c|}{8} \\
\hline & 2010 & $\mathrm{bb}$ & 2010 & $\mathrm{bb}$ & 2010 & $\mathrm{bb}$ & 2010 & $\mathrm{bb}$ & 2010 & $\mathrm{bb}$ & 2010 & $\mathrm{bb}$ & 2010 & $\mathrm{bb}$ & 2010 & $\mathrm{bb}$ \\
\hline \multicolumn{17}{|l|}{ Vertical Fenestration, U-factor } \\
\hline Non-metal Framing & 1.20 & 0.50 & 0.75 & 0.40 & 0.65 & 0.35 & 0.40 & 0.35 & 0.35 & 0.32 & 0.35 & 0.32 & 0.35 & 0.32 & 0.35 & 0.32 \\
\hline $\begin{array}{l}\text { Metal Framing (curtainwall/storefront)/ } \\
\text { Fixed Metal Framing }\end{array}$ & 1.20 & 0.57 & 0.70 & 0.57 & 0.60 & 0.50 & 0.50 & 0.42 & 0.45 & 0.42 & 0.45 & 0.42 & 0.40 & 0.38 & 0.40 & 0.38 \\
\hline Metal Framing (entrance door) & 1.20 & 1.10 & 1.10 & 0.83 & 0.90 & 0.77 & 0.85 & 0.77 & 0.80 & 0.77 & 0.80 & 0.77 & 0.80 & 0.77 & 0.8 & 0.77 \\
\hline $\begin{array}{l}\text { Metal Framing (all other)/ Operable } \\
\text { Metal Framing }\end{array}$ & 1.20 & 0.65 & 0.75 & 0.65 & 0.65 & 0.60 & 0.55 & 0.50 & 0.55 & 0.50 & 0.55 & 0.50 & 0.45 & 0.40 & 0.45 & 0.40 \\
\hline \multicolumn{17}{|l|}{ Vertical Fenestration, SHGC } \\
\hline All framing types & 0.25 & 0.25 & 0.25 & 0.25 & 0.25 & 0.25 & 0.40 & 0.40 & 0.40 & 0.40 & 0.40 & 0.40 & 0.45 & 0.45 & 0.45 & 0.45 \\
\hline
\end{tabular}

Table C.5. Addendum 90.1-2010bb Changes to Fenestration Requirements for Residential Buildings

\begin{tabular}{|c|c|c|c|c|c|c|c|c|c|c|c|c|c|c|c|c|}
\hline & \multicolumn{16}{|c|}{ Climate Zone } \\
\hline & \multicolumn{2}{|c|}{1} & \multicolumn{2}{|c|}{2} & \multicolumn{2}{|c|}{3} & \multicolumn{2}{|c|}{4} & \multicolumn{2}{|c|}{5} & \multicolumn{2}{|c|}{6} & \multicolumn{2}{|c|}{7} & \multicolumn{2}{|c|}{8} \\
\hline & 2010 & bb & 2010 & bb & 2010 & bb & 2010 & bb & 2010 & $\mathrm{bb}$ & 2010 & $\mathrm{bb}$ & 2010 & $\mathrm{bb}$ & 2010 & $\mathrm{bb}$ \\
\hline \multicolumn{17}{|l|}{ Vertical Fenestration, U-factor } \\
\hline Non-metal Framing & 1.20 & 0.50 & 0.75 & 0.40 & 0.65 & 0.35 & 0.40 & 0.35 & 0.35 & 0.32 & 0.35 & 0.32 & 0.35 & 0.32 & 0.35 & 0.32 \\
\hline $\begin{array}{l}\text { Metal Framing (curtainwall/storefront)/ } \\
\text { Fixed Metal Framing }\end{array}$ & 1.20 & 0.57 & 0.70 & 0.57 & 0.60 & 0.50 & 0.50 & 0.42 & 0.45 & 0.42 & 0.45 & 0.42 & 0.40 & 0.38 & 0.40 & 0.38 \\
\hline Metal Framing (entrance door) & 1.20 & 1.10 & 1.10 & 0.83 & 0.90 & 0.77 & 0.85 & 0.68 & 0.80 & 0.68 & 0.80 & 0.68 & 0.80 & 0.68 & 0.80 & 0.68 \\
\hline $\begin{array}{l}\text { Metal Framing (all other)/ Operable } \\
\text { Metal Framing }\end{array}$ & 1.20 & 0.65 & 0.75 & 0.65 & 0.65 & 0.6 & 0.55 & 0.50 & 0.55 & 0.50 & 0.55 & 0.50 & 0.45 & 0.40 & 0.45 & 0.40 \\
\hline \multicolumn{17}{|l|}{ Vertical Fenestration, SHGC } \\
\hline All framing types & 0.25 & 0.25 & 0.25 & 0.25 & 0.25 & 0.25 & 0.40 & 0.40 & 0.40 & 0.40 & 0.40 & 0.40 & 1.00 & 0.45 & 1.00 & 0.45 \\
\hline
\end{tabular}


Table C.6. Addendum 90.1-2010bb Changes to Fenestration Requirements for Semi-heated Buildings

\begin{tabular}{|c|c|c|c|c|c|c|c|c|c|c|c|c|c|c|c|c|}
\hline & \multicolumn{16}{|c|}{ Climate Zone } \\
\hline & \multicolumn{2}{|c|}{1} & \multicolumn{2}{|c|}{2} & \multicolumn{2}{|c|}{3} & \multicolumn{2}{|c|}{4} & \multicolumn{2}{|c|}{5} & \multicolumn{2}{|c|}{6} & \multicolumn{2}{|c|}{7} & \multicolumn{2}{|c|}{8} \\
\hline & 2010 & $\mathrm{bb}$ & 2010 & $\mathrm{bb}$ & 2010 & $\mathrm{bb}$ & 2010 & $\mathrm{bb}$ & 2010 & $\mathrm{bb}$ & 2010 & $\overline{\mathrm{bb}}$ & 2010 & $\mathrm{bb}$ & 2010 & $\mathrm{bb}$ \\
\hline \multicolumn{17}{|l|}{ Vertical Fenestration, U-factor } \\
\hline Non-metal Framing & 1.20 & 0.93 & 1.20 & 0.93 & 1.20 & 0.87 & 1.20 & 0.51 & 1.20 & 0.45 & 0.65 & 0.45 & 0.65 & 0.32 & 0.65 & 0.32 \\
\hline $\begin{array}{l}\text { Metal Framing (curtainwall/storefront)/ } \\
\text { Fixed Metal Framing }\end{array}$ & 1.20 & 1.20 & 1.20 & 1.20 & 1.20 & 1.20 & 1.20 & 0.73 & 1.20 & 0.62 & 0.60 & 0.51 & 0.60 & 0.38 & 0.60 & 0.38 \\
\hline Metal Framing (entrance door) & 1.20 & 1.20 & 1.20 & 1.20 & 1.20 & 1.20 & 1.20 & 0.81 & 1.20 & 0.70 & 0.90 & 0.59 & 0.90 & 0.44 & 0.90 & 0.44 \\
\hline $\begin{array}{l}\text { Metal Framing (all other)/ Operable } \\
\text { Metal Framing }\end{array}$ & 1.20 & 1.10 & 1.20 & 0.83 & 1.20 & 0.77 & 1.20 & 0.77 & 1.20 & 0.77 & 0.65 & 0.77 & 0.65 & 0.77 & 0.65 & 0.77 \\
\hline \multicolumn{17}{|l|}{ Vertical Fenestration, SHGC } \\
\hline All framing types & NR & NR & NR & NR & NR & NR & NR & NR & NR & NR & NR & NR & NR & NR & NR & NR \\
\hline
\end{tabular}

Table C.7. Addendum 90.1-2010bb Changes to Skylight Requirements for Non-Residential Buildings

\begin{tabular}{|c|c|c|c|c|c|c|c|c|c|c|c|c|c|c|c|c|}
\hline & \multicolumn{16}{|c|}{ Climate Zone } \\
\hline & \multicolumn{2}{|c|}{1} & \multicolumn{2}{|c|}{2} & \multicolumn{2}{|c|}{3} & \multicolumn{2}{|c|}{4} & \multicolumn{2}{|c|}{5} & \multicolumn{2}{|c|}{6} & \multicolumn{2}{|c|}{7} & \multicolumn{2}{|c|}{8} \\
\hline & 2010 & $\mathrm{bb}$ & 2010 & $\mathrm{bb}$ & 2010 & $\mathrm{bb}$ & 2010 & $\mathrm{bb}$ & 2010 & $\mathrm{bb}$ & 2010 & $\mathrm{bb}$ & 2010 & $\mathrm{bb}$ & 2010 & $\mathrm{bb}$ \\
\hline \multicolumn{17}{|c|}{ Skylights, U-factor, 0-3\% skylight area ${ }^{(a)}$} \\
\hline Skylights with curb - glass & 1.98 & 0.75 & 1.98 & 0.65 & 1.17 & 0.55 & 1.17 & 0.50 & 1.17 & 0.50 & 1.17 & 0.50 & 1.17 & 0.50 & 0.98 & 0.50 \\
\hline Skylights with curb - plastic & 1.90 & 0.75 & 1.90 & 0.65 & 1.30 & 0.55 & 1.30 & 0.50 & 1.10 & 0.50 & 0.87 & 0.50 & 0.87 & 0.50 & 0.61 & 0.50 \\
\hline Skylights without curb - all & 1.36 & 0.75 & 1.36 & 0.65 & 0.69 & 0.55 & 0.69 & 0.50 & 0.69 & 0.50 & 0.69 & 0.50 & 0.69 & 0.50 & 0.58 & 0.50 \\
\hline \multicolumn{17}{|c|}{ Skylights, SHGC, 0-2\% skylight area } \\
\hline Skylights with curb - glass & 0.36 & 0.35 & 0.36 & 0.35 & 0.39 & 0.35 & 0.49 & 0.40 & 0.49 & 0.40 & 0.49 & 0.40 & 0.68 & 1.00 & 1.00 & 1.00 \\
\hline Skylights with curb - plastic & 0.34 & 0.35 & 0.39 & 0.35 & 0.65 & 0.35 & 0.65 & 0.40 & 0.77 & 0.40 & 0.71 & 0.40 & 0.77 & 1.00 & 1.00 & 1.00 \\
\hline Skylights without curb - all & 0.36 & 0.35 & 0.36 & 0.35 & 0.39 & 0.35 & 0.49 & 0.40 & 0.49 & 0.40 & 0.49 & 0.40 & 0.68 & 1.00 & 1.00 & 1.00 \\
\hline \multicolumn{17}{|c|}{ Skylights, SHGC, 2-3\% skylight area ${ }^{(a)}$} \\
\hline Skylights with curb - glass & 0.19 & 0.35 & 0.19 & 0.35 & 0.19 & 0.35 & 0.39 & 0.35 & 0.39 & 0.35 & 0.49 & 0.35 & 0.64 & 0.35 & 1.00 & 0.35 \\
\hline Skylights with curb - plastic & 0.27 & 0.35 & 0.34 & 0.35 & 0.34 & 0.35 & 0.34 & 0.35 & 0.62 & 0.35 & 0.58 & 0.35 & 0.71 & 0.35 & 1.00 & 0.35 \\
\hline Skylights without curb - all & 0.19 & 0.35 & 0.19 & 0.35 & 0.19 & 0.35 & 0.39 & 0.35 & 0.39 & 0.35 & 0.49 & 0.35 & 0.64 & 0.35 & 1.00 & 0.35 \\
\hline
\end{tabular}


Table C.8. Addendum 90.1-2010bb Changes to Skylight Requirements for Residential Buildings

\begin{tabular}{|c|c|c|c|c|c|c|c|c|c|c|c|c|c|c|c|c|}
\hline & \multicolumn{16}{|c|}{ Climate Zone } \\
\hline & \multicolumn{2}{|c|}{1} & \multicolumn{2}{|c|}{2} & \multicolumn{2}{|c|}{3} & \multicolumn{2}{|c|}{4} & \multicolumn{2}{|c|}{5} & \multicolumn{2}{|c|}{6} & \multicolumn{2}{|c|}{7} & \multicolumn{2}{|c|}{8} \\
\hline & 2010 & $\mathrm{bb}$ & 2010 & bb & 2010 & $\mathrm{bb}$ & 2010 & $\mathrm{bb}$ & 2010 & $\mathrm{bb}$ & 2010 & $\mathrm{bb}$ & 2010 & $\mathrm{bb}$ & 2010 & $\mathrm{bb}$ \\
\hline \multicolumn{17}{|c|}{ Skylights, U-factor, 0-3\% skylight area ${ }^{(a)}$} \\
\hline Skylights with curb - glass & 1.98 & 0.75 & 1.98 & 0.65 & 1.17 & 0.55 & 1.17 & 0.50 & 1.17 & 0.50 & 0.98 & 0.50 & 1.17 & 0.50 & 0.98 & 0.50 \\
\hline Skylights with curb - plastic & 1.90 & 0.75 & 1.90 & 0.65 & 1.30 & 0.55 & 1.30 & 0.50 & 1.10 & 0.50 & 0.74 & 0.50 & 0.61 & 0.50 & 0.61 & 0.50 \\
\hline Skylights without curb - all & 1.36 & 0.75 & 1.36 & 0.65 & 0.69 & 0.55 & 0.69 & 0.50 & 0.69 & 0.50 & 0.58 & 0.50 & 0.69 & 0.50 & 0.58 & 0.50 \\
\hline \multicolumn{17}{|c|}{ Skylights, SHGC, 0-2\% skylight area } \\
\hline Skylights with curb - glass & 0.19 & 0.35 & 0.19 & 0.35 & 0.36 & 0.35 & 0.36 & 0.40 & 0.49 & 0.40 & 0.46 & 0.40 & 0.64 & 1.00 & 1.00 & 1.00 \\
\hline Skylights with curb - plastic & 0.27 & 0.35 & 0.27 & 0.35 & 0.27 & 0.35 & 0.62 & 0.40 & 0.77 & 0.40 & 0.65 & 0.40 & 0.77 & 1.00 & 1.00 & 1.00 \\
\hline Skylights without curb - all & 0.19 & 0.35 & 0.19 & 0.35 & 0.36 & 0.35 & 0.36 & 0.40 & 0.49 & 0.40 & 0.49 & 0.40 & 0.64 & 1.00 & 1.00 & 1.00 \\
\hline \multicolumn{17}{|c|}{ Skylights, SHGC, 2-3\% skylight area ${ }^{(a)}$} \\
\hline Skylights with curb - glass & 0.16 & 0.35 & 0.19 & 0.35 & 0.19 & 0.35 & 0.19 & 0.40 & 0.39 & 0.40 & 0.36 & 0.40 & 0.64 & 1.00 & 1.00 & 1.00 \\
\hline Skylights with curb - plastic & 0.27 & 0.35 & 0.27 & 0.35 & 0.27 & 0.35 & 0.27 & 0.40 & 0.62 & 0.40 & 0.55 & 0.40 & 0.77 & 1.00 & 1.00 & 1.00 \\
\hline Skylights without curb - all & 0.19 & 0.35 & 0.19 & 0.35 & 0.19 & 0.35 & 0.19 & 0.40 & 0.39 & 0.40 & 0.49 & 0.40 & 0.64 & 1.00 & 1.00 & 1.00 \\
\hline
\end{tabular}

(a) For 90.1-2010, U-factor requirements and SHGC requirements apply to skylight areas of up to 5\%. 
Table C.9. Addendum 90.1-2010bb Changes to Skylight Requirements for Semi-heated Buildings

\begin{tabular}{|c|c|c|c|c|c|c|c|c|c|c|c|c|c|c|c|c|}
\hline & \multicolumn{16}{|c|}{ Climate Zone } \\
\hline & \multicolumn{2}{|c|}{1} & \multicolumn{2}{|c|}{2} & \multicolumn{2}{|c|}{3} & \multicolumn{2}{|c|}{4} & \multicolumn{2}{|c|}{5} & \multicolumn{2}{|c|}{6} & \multicolumn{2}{|c|}{7} & \multicolumn{2}{|c|}{8} \\
\hline & 2010 & bb & 2010 & bb & 2010 & $\mathrm{bb}$ & 2010 & bb & 2010 & bb & 2010 & $\mathrm{bb}$ & 2010 & bb & 2010 & bb \\
\hline \multicolumn{17}{|c|}{ Skylights, U-factor, 0-3\% skylight area ${ }^{\text {(a) }}$} \\
\hline Skylights with curb - glass & 1.98 & 1.80 & 1.98 & 1.80 & 1.98 & 1.70 & 1.98 & 1.15 & 1.98 & 0.98 & 1.98 & 0.85 & 1.98 & 0.85 & 1.30 & 0.85 \\
\hline Skylights with curb - plastic & 1.90 & 1.80 & 1.90 & 1.80 & 1.90 & 1.70 & 1.90 & 1.15 & 1.90 & 0.98 & 1.90 & 0.85 & 1.90 & 0.85 & 1.10 & 0.85 \\
\hline Skylights without curb - all & 1.36 & 1.80 & 1.36 & 1.80 & 1.36 & 1.70 & 1.36 & 1.15 & 1.36 & 0.98 & 1.36 & 0.85 & 1.36 & 0.85 & 0.81 & 0.85 \\
\hline \multicolumn{17}{|c|}{ Skylights, SHGC, 0-2\% skylight area } \\
\hline Skylights with curb - glass & NR & NR & NR & NR & NR & NR & NR & NR & NR & NR & NR & NR & NR & NR & NR & NR \\
\hline Skylights with curb - plastic & NR & NR & NR & NR & NR & NR & NR & NR & NR & NR & NR & NR & NR & NR & NR & NR \\
\hline Skylights without curb - all & NR & NR & NR & NR & NR & NR & NR & NR & NR & NR & NR & NR & NR & NR & NR & NR \\
\hline \multicolumn{17}{|c|}{ Skylights, SHGC, 2-3\% skylight area ${ }^{(a)}$} \\
\hline Skylights with curb - glass & NR & NR & NR & NR & NR & NR & NR & NR & NR & NR & NR & NR & NR & NR & NR & NR \\
\hline Skylights with curb - plastic & NR & NR & NR & NR & NR & NR & NR & NR & NR & NR & NR & NR & NR & NR & NR & NR \\
\hline Skylights without curb - all & NR & NR & NR & NR & NR & NR & NR & NR & NR & NR & NR & NR & NR & NR & NR & NR \\
\hline
\end{tabular}




\section{Appendix D. Impact of the DOE Determination on State and Local Government}

The Unfunded Mandates Reform Act of 1995 (Pub. L. 104-4) generally requires Federal agencies to examine closely the impacts of regulatory actions on State, local, and tribal governments. Subsection 101(5) of Title I of that law defines a Federal intergovernmental mandate to include any regulation that would impose upon State, local, or tribal governments an enforceable duty, except a condition of Federal assistance or a duty arising from participating in a voluntary Federal program. Title II of that law requires each Federal agency to assess the effects of Federal regulatory actions on State, local, and tribal governments, in the aggregate, or to the private sector, other than to the extent such actions merely incorporate requirements specifically set forth in a statute. Section 202 of that title requires a Federal agency to perform an assessment of the anticipated costs and benefits of any rule that includes a Federal mandate that may result in costs to State, local, or tribal governments, or to the private sector, of $\$ 100$ million or more. Section 204 of that title requires each agency that proposes a rule containing a significant Federal intergovernmental mandate to develop an effective process for obtaining meaningful and timely input from elected officers of State, local, and tribal governments.

Upon publication of an affirmative final determination, each State would be required under Section 304 of ECPA to review and update, as necessary, the provisions of its commercial building energy code to meet or exceed the revised provisions of Standard 90.1. (42 USCU.S.C. 6833(b)(2)(B)(i)) Section 304 of ECPA requires State action in response to this affirmative determination by DOE, and the statutory requirements of ECPA require DOE to provide a determination irrespective of costs. While the processes that States may undertake to update their codes vary widely, as a general rule, a State (at a minimum) needs to:

- $\quad$ Evaluate Standard 90.1-2013 using the background material provided by DOE;

- Compare the existing State commercial building energy code to Standard 90.1-2013 to determine if an update is needed; and

- $\quad$ Update the State commercial building energy code to meet or exceed Standard 90.1-2013.

DOE evaluated the potential for State activity to exceed \$100 million in any one year. The approach looked at the three steps for minimum activity listed in the previous paragraph: evaluate, compare, and update. An additional potential step, providing training on the new code, was also considered as some States might consider training on the new code to be an integral part of adopting the new code. For the steps of minimum activity, DOE estimated the following: 
1. Evaluate Standard 90.1-2013: DOE estimated a minimum of 8 hours of review per State and a maximum review time of 500 hours of review per State (12.5 work weeks). The minimum review time of 8 hours ( 1 day) is the estimated minimum amount of time DOE can see States taking to review Standard 90.1-2013. Reading and reviewing the Federal Register notice, the qualitative analysis document and the quantitative analysis document will take the average person several hours. Deciding on whether or not to upgrade to Standard 90.1-2013 may take additional time. An upper boundary based on a maximum review time of 500 hours (62.5 days or 3 working months) was estimated as the time it would take a State not familiar with energy codes at all, or that has a particularly arduous review process to review these documents.

A cost of \$100 per hour in 2010 dollars was assumed based on actual rates proposed in subcontracts associated with compliance studies in late 2010 funded by DOE in support of the American Recovery and Reinvestment Act of 2009. The average rate calculated from these subcontracts for ten types of building officials from six States was $\$ 93.41$ (in 2010 dollars). DOE chose to round this up to $\$ 100$ per hour (2010 dollars), and then update the costs to 2014 dollars for this analysis using the Consumer Price Index from the U.S. Department of Labor, Bureau of Labor Statistics, adjusted for inflation. The 2014 cost estimate for hourly rates of the building officials is $\$ 107.27$.

a. Low estimate: 8 hours $* 50$ states $* \$ 107.27$ per hour $=\$ 42,908$

b. High estimate: 500 hours $* 50$ states $* \$ 107.27$ per hour $=\$ 2,681,750$

2. Compare Standard 90.1-2013 to existing State code: Assuming the State is familiar with its code and has effectively evaluated Standard 90.1 in the first step, the range of potential costs should be similar to Step 1. (See Step 1 for discussion of 8 hour and 500 hour times and $\$ 107.27$ per hour cost estimate.)

a. Low estimate: 8 hours $* 50$ states $* \$ 107.27$ per hour $=\$ 42,908$

b. High estimate: 500 hours $* 50$ states $* \$ 107.27$ per hour $=\$ 2,681,750$

3. Update the State codes to meet or exceed Standard 90.1-2013: Adopting a new energy code could be as simple as updating an order within the State, or it could be very complex involving hearings, testimony, etc. Again, the range of potential costs are anticipated to be similar to Step 1. (See Step 1 for discussion of origin of 8 hour and 500 hour times and \$107.27 per hour cost estimate.)

a. Low estimate: 8 hours $* 50$ states $* \$ 107.27$ per hour $=\$ 42,908$

b. High estimate: 500 hours $* 50$ states $* \$ 107.27$ per hour $=\$ 2,681,750$

The estimated range of total costs to States under these assumptions would be $\$ 129,000$ to $\$ 8.0$ million. This range is well below the $\$ 100$ million threshold specified by the Unfunded Mandates Act.

4. Train Code Officials on New Code: DOE has also considered potential costs for States to provide training on the new code. There are roughly 40,000 general purpose local governments, or jurisdictions, in the U.S., however, the total number of jurisdictions in the U.S. that enforce energy codes is not known with any degree of certainty. The National League of Cities (NLC) publishes an estimate of the number of local governments in the U.S. The most recent NLC summary (from 2007) indicates that there are 39,044 general purpose governments, including counties, municipalities, and townships. The U.S. Census Bureau also conducts a periodic census of governments (latest version is 2012). A press release on this census of governments indicates that there are:

- 3,031 counties; 
- 19,522 municipalities; and

- 16,364 townships.

This estimate from the U.S. Census Bureau equates to 38,917, which is reasonably agrees with the estimate provided by the NLC, and it is therefore assumed that there are approximately 39,000 local governments. (Note that the U.S. Census Bureau Census of Governments also tracks special districts and independent school districts, which are considered unlikely to have to adopt Standard 90.1-2013.)

In estimating maximum potential impact, DOE believes it is reasonable to assume that at least one person in all of the municipal governments, township governments, and county governments could be required to acquire some form of training on the updated Standard 90.1 in order to enforce the Standard as an adopted energy code. In addition, the 50 State governments would be required to acquire training (equates to 39,044+50 =39,094 local jurisdictions). Another widely referenced total number of code adopting jurisdictions in the U.S. is 44,000, which is based on an estimate developed by the National Conference of States on Building Codes and Standards (NCSBCS) in 1992, and repeated in many sources. (Note that there is a difference between "code adopting jurisdictions" as estimated by NCSBCS and "municipal, township, and county governments" as estimated by NLC and the U.S. Census Bureau, as local governments can have multiple code jurisdictions within them.) All these estimates are in reasonable agreement, and therefore DOE assumes that there are 40,000 jurisdictions that would potentially need training on a new energy code.

Based on experiences with conducting training sessions for jurisdictional staff, one full-day (8 hours) of training is most typical for those seeking basic training on Standard 90.1. Therefore, DOE has used 8 hours as a low estimate and 16 hours as a high estimate for training required if a jurisdiction were to adopt Standard 90.1-2013.

a. $\quad$ Low estimate: 8 hours*40,000 jurisdictions* $\$ 107.27$ per hour $=\$ 34,326,400$

b. High Estimate: 16 hours*40,000 jurisdictions $* \$ 107.27$ per hour $=\$ 68,652,800$

Adding these estimated training costs, ranging from \$34 million to \$68 million, to the previously outlined State costs indicates total costs ranging from $\$ 34.5$ million to $\$ 76.7$ million. The high end of this estimate is less than the $\$ 100$ million threshold in the Unfunded Mandates Act. Accordingly, no further action is required under the Unfunded Mandates Reform Act of 1995 


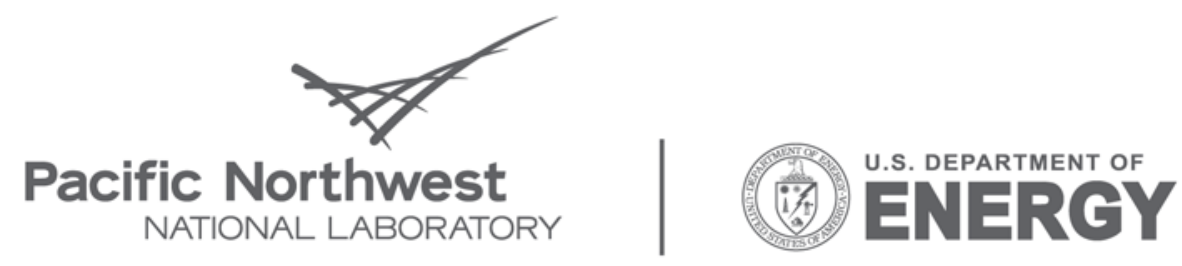

Proudly Operated by Battelle Since 1965

902 Battelle Boulevard

P.O. Box 999

Richland, WA 99352

1-888-375-PNNL (7665)

www.pnl.gov 